University of Louisville

ThinkIR: The University of Louisville's Institutional Repository

Electronic Theses and Dissertations

1941

\title{
A study of the Family Service Organization, Louisville, Kentucky, in reference to intake, 1884-1940.
}

Marian Elizabeth Prinz

University of Louisville

Follow this and additional works at: https://ir.library.louisville.edu/etd

Part of the Social Work Commons

\section{Recommended Citation}

Prinz, Marian Elizabeth, "A study of the Family Service Organization, Louisville, Kentucky, in reference to intake, 1884-1940." (1941). Electronic Theses and Dissertations. Paper 2121.

https://doi.org/10.18297/etd/2121

This Master's Thesis is brought to you for free and open access by ThinkIR: The University of Louisville's Institutional Repository. It has been accepted for inclusion in Electronic Theses and Dissertations by an authorized administrator of ThinkIR: The University of Louisville's Institutional Repository. This title appears here courtesy of the author, who has retained all other copyrights. For more information, please contact thinkir@louisville.edu. 
UNIVERSITY OF IOUISVILLE

A STUDY OF THE FAMILY SERVICE ORGANIZATION, LOUISVILLE, KENTUCKY, IN REFERENCE TO INTAKE

$$
1884-1940
$$

\author{
A Dissertation \\ Submitted to the Faculty \\ Of the Graduate School of the University of Louisville \\ In Partial Fulfillment of the \\ Requirements for the Degree \\ of Master of Science in Social Administration
}

Division of Social Administration

By

Marian Elizabeth Prinz

1941 
This PDF document is a scanned copy of a paper manuscript housed in the University of Louisville (UofL) Libraries. The quality of this reproduction is greatly dependent upon the condition of the original paper copy. Indistinct print and poor quality illustrations are a direct reflection of the quality of materials that are available for scanning. The UofL Libraries greatly appreciates any better copies that can be made available for replacement scans. 
NAME OF STUDENT: Marian Elizabeth Prinz

TITLE OF THESIS: A Study of the Family Service Organization, Louisville, Kentucky, in Reference to Intake

$$
1884-1940
$$

APPROVED BY READING COMMITTEE COMPOSED OF THE FOLLOWING MEMBERS:

Margaret K. Strong

Lois Blakey

Samuel C. Newman

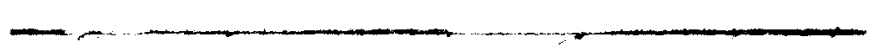

Gardner F. Cook

NAME OF DIRECTOR: Dr. Margaret $\mathrm{K}$. strong

DATE: May 31,1941 


\section{ACKNOWLEDGEMENT}

For asofstance mith this theajs the rriter wishes to exnreas her appreciotion to many inrividuals. The mriter wahes to acknowledpe ospecially her orstitute to Dr. Margaret $K$. Strong and to Mise Lois Blakey for their kind assistance, encouragement, and personal midance; to Miss Esther Taylor for sugeestions and for her kindness in placing the coae recorde and other material of the Family service organiagtion at her disnosal; and to nther members of the Family Service Organization staff for their helpfulness. 
A STUDY OF THE FAMILY SERVICE ORGANIZATION, LOUISVILLE, KENTUCKY, IN REFERENCE TO INTAKE

$$
1884-1940
$$


TABEE OF CONTENTS

IITTRODUCTION

Page

CHAPTER

I. A CHANGING PHILOSOPHY OF SOCIAL CASE WORK 10

The Broad Historical Setting 11

The Historical Development of the Family

Service Organization

II. A DEVELOPING INTAKE PROCESS IN THE FAMILY

SERVICE ORGANIZATION 1884 - 1938

The Charity Organization Society $1884-1907 \quad 41$

The Associated Charities 1907 - 1921

The Family Service Organization 1921 - 192960

The Family Service Organization 1929 - 193878

III. ANALYSIS OF THE INTAKE PROCESS IN THE FAMILY SERVICE ORGANIZATION 1939 - 1940

Developments in Intake Set Up and Policies in 1939 and 1940 in the Family Service Organization

General Statistics on Intake of the Family Service organization $1939-1940$

Statistics Compiled for Sample of 249 Major Care Acceptances (Negro and White) for $1939-1940$

Analysis of Source of Intake 140

Personal Application

Referrals by Individuals

Referrals from Other Agencies

140

143

147

Problems Presented in the Intake Interview 
TABLE OF CONTENTS, cont.

Services Offered in the Intake Interview

Page

Reasons for Acceptance

160

166

Client-Worker Relationship

176

CONCLUSION AN EVALUATION IN PERSPECTIVE AND INDICATIONS FOR FUTURE DEVELOPMENT

APPENDIX

i

BIBLIOGRAPHY

$\operatorname{xxX}$ 
INTRODUCTION 


\section{INT:RODUCTION}

This study of the intake process and policies of the Family Service Organization is approached from the general point of view of ascertaining how the Family Service Organization, as a private family agency, is now functioning at the intake desk in the light of a developing intake process since the organization of the agency in 1884. This study is first approached with the hope not only that it may help to elucidate, for the Family Service Organization staff, the present intake process and attendant skills in the light of a developing process; but also that it may serve as a challenge for further refinement of skills in the area of client-worker relationship, for growth in the technique of the intake methods, and for further facilitation in the handling of the mechanics of the intake interview. The second reason for this study is the desire that it may prove helpful to other social agencies in the city in interpreting the function of the Family Service Organization as defined at the intake desk and that through this increased understanding the Family Service organization may be of increasing service to other agencies both in a consultative and in a referral capacity.

The third motive for the study which is related to 
the otier two is found in the conviction that as the Agency is consciously aware of its developing techniques and skills at intake and is aware of the need for a continuous growth process, it can better serve the client around whom all methog technique, and process centers and can interpret anà make this service available to the community which it serves.

$$
\begin{aligned}
& \text { "The intake interview is the time of int- } \\
& \text { roduction of the client to the agency. It } \\
& \text { is the occasion for the decisions as to } \\
& \text { whether the agency has service to offer } \\
& \text { the client and whether the client is int- } \\
& \text { erested in acceptence of that service." }
\end{aligned}
$$

The intake process is the first step in social study, and caseworkers have become increasingly aware of this process as an integral part of the total case work treatment plan. What have been the developing intake policies of the Family Service Organization as defined at the intake desk? Why have clients come to the agency and what have they requested? What problems have they brought? How has the intake interviewer met these needs in relation to what the agency has to offer? What has been the changing philosophy of intake policies in the Family Service Organization? Who has referred cases to the Agency? To what extent have the services of the Family Service Organization been used by the economically independent? By other agencies? How have the developing skills of the intake interviewer affected performance in relation to the clientworker relationship? Did the Fanily Service Organization

I.

Dr. Leroy M. A. Maeder in an Institute held Juty 1940, Minneapolis, Hinnesota, Fanily Welfare Association of America. 
in 1940, in the crystallization of a developing intake process, have new contributions to make to the clarification of intake procedure and the many ramifications of casework skills involved?

This study is based on the reading of a sample of five hundred major care intake interviews, cases acceptea by the Family Service Orgianization during the period 18841940. Sixty-five interviews were read for the period 18841921, seventy-five interviews for 1921-1929, one hundred and eleven interviews for 1930-1938, and one hundred and five interviews were read for 1939. Of this one hundred and five, fifty-five had been read and statistics tabulated for a similar briefer study made in January 1940. Half of the total major case intake for 1940, or one hunäred and forty-four interviews were read for 1940. Intake interviews up to the period 1930-1938 were consistently brief and similar in content. There was little process recorded. It was not until 1938, 1939, and 1940 that the intake interview was recorded in nore detail and more of the client-worker relationship was discernible. Accordingly, a larger sample of cases was read for the last three years included in the study than for the earlier years.

A schedule was filled out for each interview read (see Appendix I) including questions as to identifying information, source of intake, status of the application or applicant, family status, mechanics of the intake interview, what the client requested, definition of agency function and services offered in relation to the problem presented, reason 
for acceptance of the case, possible solution of the problem as seen by the client and the worker, plan for the next contact, and evaluation of the activity of the client and of the caseworker.

Statistical reports of the agency; minutes of the Charity Organization Society and the Associated Charities Central Council meetings and of the Family Service Organization Board meetings and Board Committee meetings; Agency annual reports; special studies made within the Fawily Service Organization (see Bibliography); the Cormunity Chest survey study made in 1939; Family Welfare Association of America studies of the Agency and annual reports sent to the Family welfare Association of America; reports of general secretaries of the Charity Organization Society, the Associated Charities, and the Family Service Organization; minutes of the Family Service Organization intake committees; Agency reports prepared for lay interpretation; and agency memorandum naterial were valuable spurces of information. Haterial on the history of the Agency was obtained in part from a thesis written by Mrs. Bernice Ellis in 1940-41, caseworker in the Family Service Organization, on the history of the Family Service Organization 1884 - 1939.

Interviews with Miss Esther Taylor, executive secretary of the Family Service Organization (1930 to the present time), and with ifiss Virginia Sympson, registrar of the Family Service Organization (1925 to the present time) were also helpful in interpreting findings. Informal discussions with other Family Service Organization staff members helped 
to give perspective to the study.

Directional reading was available through literature of the field (see Bibliography).

The method employed was primarily that of a casework approach. Case material was read and a schedule was kept on each interview. Material was tabulated and analyzed and conclusions were drawn. A statistical approach was used in compilation and analyzation of statistics. An historical approach was used in tracing the intake set up and philosophy within the agency and as it paralleled the general development of casework thinking.

As the development of the intake process is traced, little mention is made in this study of the actual activities of the Agency Board and Staff and their part in bringing about these developments. Hajor exphasis will be placed on the casework approach. The other areas are taken up both by Mrs. Bernice Ellis and Miss Hildred Bateman, staff members of the Family Service Organization who are writing theses on the history of the agency and on lay participation respectively.

In evaluating this study it must be taken into consideration that findings are based on intake material drawn from major case acceptances. In reality this does not give a total picture of intake functioning of the Family Service Organization but does include the dominant intake processes.

For purposes of clarification the areas of intake classification may be defined as follows:

A major care case is a case for which the Agency, after careful consideration, as- 
sumes the responsibility for making a social diagnosis and for helping to carry out a plan of treatment. A minor care case is a case where an interview is held and careful attention given once or more than once, but for which responsibility is not taken for making a complete diagnosis and carrying out a plan of treatment. This does not necessarily imply that little attention is given the case.

The Family Service Organization interprets a service to a client or to a community person essentially as the above. In a memorandum sent by iliss Esther Taylor, executive secretary of the Family Service Organization, to the districts in August 1939, she urged that any interview (except major care acceptances) where it was thought that the interviewer gave some real help to a client even though the client was to be referred to another agency should be termed a minor service case.

Table I (see Appenoix II) shows intake in the Family Service Organization, major and minor care cases 19211940 .

Major care cases plus minor care cases carried during any given wonth comprise the caseworker's total case load.

Referral: This intake classification implies that the client or person interested in a client has been referred to another agency and the Family Service Organization has no service to offer. It implies that the client was seeking no help in deciding where to apply or in accepting referral to other sources.

Rejection:This intake classification implies that the Family Service Organization can offer the client no help, that he does not want or cannot use help offered by the agency. 
Report on

closed case: This intake service involves

giving reports to other agen-

cies or to individuals, inter-

preting the Family Service Or-

ganization's previous contact

with clients.

Broken appointment: This intake class1-

fication indicates that the

client broke an appointment

given him.

To further define terms, cases are classified as new, old, or recurrent at the time the client applies or the case is referred to the agency.

A new family has not been known to the Family Service Organization and is applying for the first time. An old application has been known to the Family Service Organization either as a major care or as a minor care case previous to the current year during which client is applying.

A recurrent application has been known to the Family Service Organization either as a major care case or as a minor care case previously during the current year in which the client is applying.

Statistical information used in this study must be considered in view of certain limitations. Previous to 1930 there was no uniform method of keeping statistics within the agency, so that interpretation of the terms is not always accurate. From 1930 through 1940, howvver, statistics were kept uniformly and were counter-checked for accuracy. Previous to 1930 to 1935 the term "trained worker", for the most part, connoted a worker with experience but 
with little formal tecinical training in a school of social work. "Irained worker" now connotes a worker who is a gracuate of an approved school of social work. 
CHAPTER I

A CHANGING PHILOSOPHY OF SOCIAL CASE WORK 
Chapter I

A Changing Philosophy of Social Case Work The Broad Historical Setting

Before consiaering the problem of intake in the Family Service Organization in any definite time setting or in any specific sense as a part of the progressive development of casework techniques and functions, it is possible to find orientation by briefly tracing the broad historical development of social casework, its emerging emphases and changing philosophies. We are aware of the link between knowledge and practice, the need to know history to give us light in our creative thinking.

Previous to the twentieth century there was no profession of social work. Professional status had its beginning in the transition from the idea of helping people as "doing good" to the idea of helping people as an art based on scientific knowledge.

Long before there was any organized charity people helped each other naturally as friends and neighbors. Various social and political structures have differed in their means of meeting problems of "caring for the poor". The first three centuries were marked by "fixity and isolation". In the Medieval period, the fifth to the fifteenth centuries, there was an organized neighborliness through institutional care and organization of merchant and craft guilds. The fifteenth and sixteenth centuries faced disaster relief and continued institutional care as 
ways of meeting social problems.

Up to the sixteenth century poor relief was in the hands of religious organizations and private societies. Almsgiving carried something of sanctity with moral benefit to the giver and the recipient. Following the break up of the feudal system the country was disturbed by wanderers. The state was forced to step in and positive measures were introduced. Early social legislation was aimed at punishing rogues and vagabonds with the inherent psychology of fear and repression. In 1601, in England, the first poor law, the "Forty-third of Elizabeth", recognized public responsibility for care of the indieent. Its provisions centered in the principles of local responsibility, fanily responsibility, settlement, and setting to work of the indigent. There were appalling wisuses of the law. It failed to meet the problem, and in 1790 Robert halthus in his "Essay on Population" advocated starving out the paupers.

The poor law in England remained basically unchanged until 1834 when the law was changed following a Foyal Commission study. Control was taken away from the parish and placed in the hands of Justices of the Peace, starting the office of poor law official. There was an increasing sense of national leadership and effort toward national uniforroity. The principle of less eligibility emphasized that the standard of those in need of alms should be kept lower than the standard of the lowest independent laborer. The third principle was the workhouse test. No one refusing to go to the almshouse or workhouse was 
deened eligible for relief, thus limiting all public relief to institutions. This was not practical and the abuses were many.

A third revision in the English Poor Law was made following another Royal Comnission Report in 1909. Old concepts were repudiated and three new concepts emerged which were theoretical at that time but through the years have become more of a reality. The first was the concept of universal provision. This implied a national minimum for care of the poor. The second concept of curative treatment repudiated the older concept of repression and starving out the poor. The third concept of social control implied an element of compulsion -- the idea of regulation. These three concepts forned the basis for a developing democratic program of public assistance.

Tracing development rapidly, historians name St. Vincent de Paul, a French priest in Paris of the sixteenth century, as the first social caseworker. His contact with prisoners was personal as well as religious. The Hamburg system of the eighteenth century had rudiments of a more modern approach to relief giving with its opposition to indiscriminate relief giving and its stand for the removal of the causes of pauperism. In 1830 the Society of St. Vincent de Paul forined under the leadership of Frederick Ozanam in Paris evidences a beginning awareness of techniques of giving help. A group of young entinusiasts sought to show the fallacy of the fashionable skepticism of the age by devoting thenselves to the service 
of the poor in their homes and to an attempt to check pauperization if possible.

In 1852 the Elberfeld system in Westphalia introduced the use of volunteer workers, the giving of adequate outdoor relief to the poor and giving relief in money. Thomas Chaliners in Scotland about this time eraphasized character in the poor and advocated neighborliness as a solution of the problem of relief giving.

\section{In 1869 the London Charity Orsanizetion society} was or minized as a protest against the abuses of charitable relief. Neither poor law reloras nor private societies had iaproved conditions of pauperism. There followed a period of social reform and experiment with the notable work of such people as the Earl of Shaftesbury in the field of child labor and octavia Hill crusading for better housing. The purpose of the London Charity Organization Soclety was the "organization of relief rather than its creation". It sought to bring about cooperation between public and private agencies. The london Charity organization Society was to serve as an example in orgenization and set up of the Charity Organization Society movement in the Unitea States.

In the United States we can trace the development of the care of the poor through private benevolence, church, tinen state provision to federal participation and public assistance programs. A few landmarks in this development are outstanding. In 1817 the New York Society for the Prevention of Pauperism was established with emphases on the causes of pauperism and a strong noral note. In the Yates 
and quincey reports in the period 1820-1824 in $\mathrm{ew}_{\text {Y }}$ York and inassachusetts, institutional care was given as the answer. Emphasis wes on restraint. The poor wese looked upon as undesirables to be punisied and reformed.

Throughout history three characteristic attitudes toward poverty and charity maj be traced. First there was a dominant attitude idealizing poverty in preterence to riches. A second attitude was one of a ciesire to relieve poverty and distress, and the third the attitude prevalent from about 1500 of repressing mendicity and reducing expenditures on the poor. This attitude is prevalent in the penal characteristics of the early poor laws. In 1843 the Association for Improving the Conditions of the Poor was organized in New York. This organization sought a more humane and personal interest in the needy. Districts were set up and volunteer workers sought to make "character adjustments".

Charity of the nineteenth century was the charity of one social class extended to another social class. The tremendous economic and social changes involved in the appearance of the factory system, the growth of cities, increased mobility and realignment of classes gave rise to new problems of health, housing, child, labor, women in inaustry, alternating boom and depression, immigration, etc. Also new motives and new sponsors for charity appeared. The new middle class was interested in humanitarianism. "Welfare work" became a device for gaining social recog- 
nition and power. The "Lady bountiful" and "slumining" concepts appeared. A host of relief societies appeared such as the Association for Improving the Conditions of the Poor, already mentioned.

The year 1863 is significant in respect to state organization for public assistance. The first state Board of Charities was established in Hassachusetts in tris year. In 1870 the first National Conference of Charities and Corrections (later the National Conference of Social Work) met.

In 1370 the Buffalo Charity Orsanization Society was organized with the distinguishing point of emphasis not on relief but on service. Patterned after the London Charity Organization Society, the purposes of the organization were correlation of work, repression of public outdoor relief, no relief giving but mediation between client and possible sources of relief. The methods used were registration of applicants, investigation and the keeping of case records, friendly visiting by volunteer service and repression of begging. "Friendly visiting" and "spiritual alms" were the very soul of the movement. The Charity Organization Societies fostered the use of the "case method" with the ends in view of family rehabilitation, education of the public in correct principles of relief giving, and elimination of causes of poverty. The Charity Orsanization Society movenent was the forerunner of Community Chest and Family Welfare Organiza- 
tions. The Charity Organization Society movement typified the first scientific method of administration of relief giving and of treatment of human relationships.

In the Eighties social settlements were organized. Private agencies continued to be maintained by the upper one fourtin for the lower one fourtin of society.

Gradually social work was beginning to emerge as a profession with efforts to define tasks clearly and to develop knowledge and skill necessary for performance. There was a growing concern about techniques.

Family Welfare Agencies appeared as outgrowtins of the Charity Organization Society movenent. The early functions of Family Welfare Agencies covered many activities in the organization of comunity forces. The turning point came in 1919 when the report of a committee on future scope and policy (appointed by the American Association for Organizing Charity) expressed the conviction that the family ratier than the commuty should be regarded as the peculiar unit of charity organization and suggested the words "family social work" be incorporated in naraes of local agencies. The Family Welfare Agencies were characterized by belief in social diagnoses and treatment and in cooperative planning.

In the period from 1890 to 1900 volunteers began to yive way to paid workers. In 1891 training courses were introduced in the Brooklyn Society. In 1898 the New York School of Social hork was organized. Also the Association 
of Societies for Organizing Charity was established which later became the Family Welfare Association of America with emphasis on development of professional standards, values of social case work, and adequacy of relief. The publication of Hary Richnond's Social Diasnosis in 1917 marked an epoch -- the biginning of scientific literature of the field. In 1918 the Smith College School of Social Work was established with its interest in the psyshiatric approach.

The World War left its aftermath in disrupted lives and physical and mental illness. This led to a new interest in the psychology of the individual. The family field was quick to respond. Both the psychiatric and the psychoanalytical fields had a profound influence on social case work.

1921 saw the beginning of professional associations for social workers and the emergence of the concept of a basic or generic case work practice. The family was accepted as the "unit of work". There was a process of transition from an economic to a sociological viewpoint. Emotional factors began to be studied through stimulus of work in child guidance clinics and mental hygiene clinics. Gradually there was developing, as lfary Richmond expresses it in What Is Social Case Work? (1922), an "ecucationally comrnunicable technique" known as social work, those "processes which develop personality through social adjustments, consciously effected, individual by individual, between 
man and his social environment". There was a new emphasis on trained personnel. The spirit of charity was being replaced by the spirit of democracy and the spirit of science.

The Milford Conference Report of 1929 showed more stress being laid on the client's own purposes and that the "distinguishing concern of social case work is the capacity of the individual to organize his own normal social activities in any given environment". In the following year, 1930, Dr. Virginia Robinson's book made an interpretation of the reciprocal nature of the workerclient relationship, stressing the self-determination and free will of the client as the center of diagnostic and treatment concern.

The period from 1930 to 1940 was one of transition. The crisis of 1929 and the following depression found private funds totally inadequate to meet the need. From 1930 to 1932 private agencies were in the vanguard for public assistance programs. Casework again turned toward outer environment rather than inner. In the report Recent Social Trends during President Hoover's administration, the necessity for long time public planning was emphasized. When President Roosevelt took office in 1932 rapid developments followed in public assistance programs. In 1930 "public welfare" was significantly defined by Professor Odum in Recent Social Trends as "that function of government which aims at making democracy effective in the un- 
equal places". This connoted security, adequacy, and the legal right to relief.

In 1932 the Federal Emergency Felief Administration prograin was set up, followed in succeeding years by the National Industrial Recovery Act, Civil Vorks Aorinistration, Public Works Administration, Civilian Conservation Corps, Works Progress Acministration, and National Youth Administration, a fluctuation between relief enö work prograns. The prograin culminated in the Social Security Act in sugust 1935 with provisions concerning vocational rehabilitation, public health, eid to the blind, aiả to depenàent chilaren, unemployment compensation, old age assistance, olả age insurance, and, later, survivors' insurance.

The family field philosophy was now one of relinquishing relief as its wost characteristic function. There was a groping to derine function. Consulting psychiatrists vere employed. There were tendencies toward greater specialization with interplay betveen specific and general. Function was not rigid and static.

The period of transition has involved denying waterial aid to clients except as the relief funds are used for special needs, in a constructive program to prevent breakdown and to promote the stability of individuals and families. During the past forty years the conscious development of the social case work approach has been rapid. There has been a shift of emphasis between preoccupation 
with psychological factors and with environmental factors of the client's life. Just as intensive environmental manipulation of the first twenty years led to an impasse, so intensive direct treatment led to another sort of impasse until case workers rediscovered their social function and differential treatment was undertaken. There has been accomplished the shift from social case work as an expression of benevolence and superior wisdom in behalf of inferior groups to a professional service potentially useful to persons in all walks of life.

Two most important influences in the past decade for social case work were psychiatric insight and economic pressure leading at the same time to a more democratic as well as more diagnostic approach to individual problems. Social work follows the economic and cultural pattern of its time.

In review we can trace steps in the development of social case work through periods of philanthropic individualism, individual pauperism, social poverty, and psychoanalytic and psychological study influences. The depression led to federal participation in public assistance and the family agency's relinquishing its dominant relief function to face a period of redefinition of function and a return to service in family counseling in terms of a fusion of skills, economic, environmental and emotional. This development has made intake procedure a recognized and featured part of the case work process necessitating 
the most skilled service of the agency. 
The Historical Development of the Family Service Organization

For a history of the Family Service Organization, material has been dram primarily from a thesis by Mrs. Bernice Ellis (the first complied material on the history of the agency) and partly from minutes of the Family Service Organization board of directors, the Case Policy Committee, the reports of general secretaries, and annual reports of the agency. Mrs. EIlis has outlined the periods of development of the Family Service Organization in the following phases: The period of the Charity Organization Society 1884 to 1907; the period of the Associated Charities 1907 to 1921; and the periods of the Family Service Organization 1921 to 1929 , characterized in attempts to define function in terms of individual needs apart from relief needs; 1929 to 1938 period of public subsidy and development of a department of public welfare in Louisville; and the year 1939 when the agency had been relieved of the major relief burden and sought to redefine the function of the family agency.

The development of the Family Service Organization parallels the general development of social case work thinking as outlined in the previous section but there is a tendency for the agency to lag several years behind the general trends.

Prior to the organization of the Louisville Char- 
ity Organization Society in 1884 , private charities and institutions were primarily of religious and national groups. There was no coordination and much duplication among the inany sindl private charities. The first Louisville Charity Organization Socìety was established in 1836, with a staff of ten volunteers and the purpose "to feed the hungry, clothe the naked, mitigate the conditions of the bereaved sufferers under the severe distress of poverty". I At this time there was no public outdoor relief except city distribution of a limited anount of coal from the general revenue fund.

A group of influential Louisville citizens were instrumental in organizing the Charity Organization Society of Louisville which received its charter on Hay 9, 1884. The agency functioned under the name Charity Organization society from 1884 to 1907. The agency during this period placed emphasis on deterrence of fraudulent claims, on saving the citizen's dollar, on preventing indiscriminate almsgiving and avoiding duplication. The Charity Organization Society period of development might be called curative in emphasis -- an interest in taking care of persons in need.

The Charity Organization Society followed the leadership of the general Charity Organization Society movement including the district plan of organization, a spirit of neighborliness, and the use of friendly visit- 
ing. The policy raking power was in the hands of the Central Council (later Board of Directors). The superintendent (later executive secretary) and two district agents (later supervisors) were the only paid employees. Friendly visitors, residents of the district in which they visited, had not more than four fanilies under care at a time to whom they gave "counsel and advice". District committees were organized in each of the two districts to bring local charitable organizations into cooperation, to prevent indiscriminate and duplicated alusgiving, to secure investigation, to find work for clients, to prevent begging, and to promote the general welfare of the district. Applications were received by the district agents and decisions were made on the basis of merit and need of the client in conference of the district committees, asents, and visitors. This was a inethod of diagnosis as well as an educative process. Decisions were based on the standards of the givers who judged clients' neeas in terms of noral fitness. (Some headings of newspaper clippings of 1895 mirror this attitude -- "She is a Fraud", "A Tramp Crook", "No Dead Beats Will Be Assisted", Month of Good Deeds", "Making Paupers", "A Fickle Actress", etc.) If accepted, the applicant was referred to the person or society who could best meet his inancial need. Relief was given on the basis of work. "If a man will not work, neither shall he eat".

A registration was kept of applicants. This was 
the beginning of the present Social Service Exchange service (established in 1914 as a separate organization). By 1905 work of the society was enlarged to include a department for work among negroes. In the period from 1903 to 1907 the foremost problem was that of "wife deserter".

Causes of poverty were seen primarily as the lack of industry, judgement, or thrift. The blame was placed on the client. From 1885 to 1919 the problem of the transient was a major responsibility and was carried mainly through the work of the Wayfarer's Lodge. Men were given room and board in return for work in the woodyard.

In 1907 the name of the Charity Organization Society was changed to the Associated Charities. The period of the Associated Charities lasted from 1907 to 1921. Emphasis in this period was on prevention. The administrative set up was not changed although later there were three districts instead of two. In two years' time the agency saw the need to increase relief funds, to engage a trained social worker as superintendent, and to substitute trained visitors for volunteers. This would permit the investigating agency to carry on treatment even though relief was needed. Previously relief giving had been thought of as impeding service to families, this concept originating at the time of the establishment of the London Charity Organization Society.

The first trained executive in the Associated 
Charities was Hiss Harriett Anderson, who came to the agency in 1910. She was a graduate of the New York School of Philanthropy which had been organized in 1904. From this point the actual work of the agency was carried on by additional paid staff members rather than volunteers. Volunteers often followed up original investigations made by employed workers.

the agency was concerned during this period with social reform particularly in reference to the "loan law" and tenement house bill. Other activities of the agency included legal aid work handled through a legal aid committee under the Central Council giving legal advice and consultation to clients. Work toward organization of a Social Service Exchange was furthered. The Associated Charities continued its relief work but gave financial aid only after all other resources were exhausted. In 1915 the Associated Charities accepted four thousznd two hundred eighteen applications for investigations for other agencies. In 1916 an employment bureau functioned and an Associated Charities worker was loaned four half days a week to Calvary Church. The Associated Charities became a member of the American Association for Organizing Family Social Work.

By 1917 there were four districts with a trained worker in each aistrict. inontily reports were how kept by the supervisors. There was a revision in iletnoa of keeping statistics although there continued to be a Iack of 
uniformity in definition of terms. In tilis year tie first Negro worker was employed. The Louisville Federation of Social Agencies was organized which later became the Welfare League and finally in 1923 the Community Chest. In 1918 there were eight staff members. Unsettled conditions of the country intensified the need for skilled service and cooperation of communty resources. The Associated Charities furnished trained workers to make investigations for applications for city coal, for admittance of clients to the Home of the Aged and Infirm, for admittance to the Home of the Incurables, the East End Day Nursery, and the Union Gospel Mission. Wayfarer's Lodge was closed because of lack of applications. The Associated Charities provided bed and linen for emergency hospitals during the flu epidemic, a worker was loaned to the American Red Cross, etc. In ilay of this year the employment bureau was discontinued.

The close of 1921 saw an increased number of relief applications. The services of a Fome Economist on the staff were available. There was a growing empasis on the service function of the agency.

In December 1921 the name of the Associated Charities was changed to the Family Service Organization as the Associated Charities did not convey the idea of service given. In the period of Family Service Organization development from 1921 to 1929, focus was on family relations, a new emphasis. This was a period of "federation, 
standaraization, and unification". This period was characterized by the movement toward governmental support of classes of families as the responsibility of public assistance programs. Louisville was slow in developing a public assistance program and it was not until 1925 that the Family Service Organization had any very active part in pointing out the need for a public assistance program. In Board minutes of 1923 we find the first mention of closing intake temporarily to families who in other cities were cared for in public assistance programs.

The years from 1925 to 1929 were years of continued stress for the agency. Hr. Linton B. Swift, general secretary of the Family Service Organization from 1922 to 1925, left the agency in 1925 and was succeeded by $\mathrm{Mr}$. Paul Benjamin, who writes graphically of the situation facing the agency. There was the continuous problem of unemploynent and the problem of transients. Pressure for trained workers was great and rapid staff turnover was serious. In a six month's report, January 1, 1925, Mr. Benjamin pointed out that demands were heaviest in the history of the society causing an overdraft on the budget. The Family Service Organization was serving as a "relief buffer" for the entire relief needs of the community. Unemployment was mounting.

The principle causes bringing people to the agency were listed as unemployment, wiojowhood, desertion, non-support, old aze, and chronic illness. The lack of 
facilities for the care of certain groups of people was deplored. There was no provision at the Home of the Aged and the Infirm for aged married couples, and there was a watting list for the Hone for Incurables. Groups in need of institutional care -- drug addicts, the mentally ill, the feebleminded -- constituted grave probleins. The agency saia there must be assistance from public taxation. The only help from tax money was six hundred tons of coal a year. If no roney was forthcoming the Family service organization case policy comittee recommended refusing help to certain categories -- the aged, the chronically ill, the unemployed, discbled ex-soldiers, widows, tine feebleminded, and epileptics -- seeing these categories as public responsibility.

In 1925 the services of the staff Home Economist were discontinued. All work in the county wes discontinued after April 1, 1925. A caseworker was first placed at the application and information desik on June 1, 1925, as the board recognized the growing inportance of a more skilled intake job.

Froin 1925 to 1929 the agency was used as a kind of coimunity "pocketbook" for other agencies and became a "scrap basket" doing what there was no other agency to do. There was a constant increase in work without any clear definition of function. In a report of the general secretary in April 1927 he stated the philosophy of the staff and the Board in terms of "helpfulness to all in 
need in our comnunity".

During this period agency reports describe a stron staff doing an intensive driving kind of work carrying a load borne largely by public agencies in other cities. In 1926 there was an increase of $25 \%$ in cuse loads and $5.3 \%$ in staff. Relief was inadequate. The agency made appeals for preventive work which it thought was being neglected. It was necessary to neglect service cases. The importance of social planning was stressed. The work of the agency was focused on the establishment of a public welfare department in the city. By April 1927 other agencies were informed that it was impossible for the Family Service Orsanization to meet expenditures for uaterial assistance for clients of other agencies except in unusual cases. During this period there was stimulus from tine Family Welfare Association of America, setting up objectives for family agencies in terms of adequate staff, clearer divisions of responsibility, development of more resources, reduction of case loads, services to families above the poverty line, and improvement in techniques.

By 1929 pressure was intense with a $17 \%$ increase in intake in January 1929 over January 1928 with no increase in staff. The agency was in efiect an emergency relief organization. In February 1929 the Board was considering recommendation that all service cases be closed. It is pertinent to note here that when it was necessary in the period from 1929 to 1938 for the agency board to 
think in tems of limiting services and where there was a definite need, they worked toward stiralating new resources to meet these needs. The staff was working in the evenings and all day on saturdays. The agency pled for a program of rehabilitation and construction rather than of alnsgiving.

The history of the Family Service Organization from 1929 through 1938 inay be cescribed as a period of public subsidy and of the development of a department of public welfare. In this period the outstanding probleas were: one, unemployment following the 1929 crisis; two, concern over relief needs of the community; three, public subsidy; four, relief function of a private agency; five, need to aefine function of the family agency and confining work within this function; and six, development of an adequate staff.

Until 1930 there was the widespread impression that the private agency was primarily responsible for the relief needs of the communty. Seeking public subsidy was the first stage in the development of public relief administration. although the system was seen as injurious to both public and private interests. In Louisville the Family Bervice Organization requested and received public subsiỏy. There was no public agency and the public grant was given in a yearly sum to the private agency to ineet an einergency situetion with no long time plan for the future in view. The money was to be used for families of the able 
bodied unemployed.

On Novenber 11, 1930, the City Uneinploynent Relief Bureau opened. This was not to be regarded as an agency for general relief. Wages averaging thirty dollars a month per worker were to be paid in a work program. In 1931 a study of the subsidy systein wa: made by Harriett Iynes, a Family bervice Organization staff member. Of several alternatives presented the Board passed on the proposal to assuie only case work as the responsibility of the Fanily Service Organization, but to continue to carry unenployment relief cases temporarily for the city with the understanding that a derinite date was to be fixed at which time the city would take over this responsibility. onfy most urgent cases were accepted at tile intake desk. In November an einergency district was set up. This was expensive. No detailea cuse histories were ket. Relief giving ws indiscrininate. There were large case loads and few workers. This cistrict was set up as a mean of easy transfer of ceses to the public agency.

In 1931 the inunicipal Relief bureau work roject was aiscontinued. Increasing complexity of the needs in the field of social work was forcing organizations to realize that no family agency could care for all persons in need in the community. The Fanily Service Organization would assist resident fainilies with children and would give some assistance to non-residents to return them to their legal residence. The Fanily Service Organization could not care for young or aged couples, single 
men or women, or children without parents. Unemployment situations were being referred to the nunicipal Relief Bureau. 1930 to 1938 was a period of gradual transfer of cases from Family Service Organization to the public agency.

In 1933 the Hunicipal Relief Bureau adininistered federal funds, using the federal funds for unemployment cases and local funds for their city division including direct relief for the aged, incapacitated, single adults, the blind, pending wothers' Aid cases and cases of chronic illness. During this period there were difficulties in working relationships. The innicipal Relief Bureau had too few workers. There were periods of closed intake and delays in caring for cases. During this period the Fanily Service Urganization offerea interviewing service and referral services. This meant an added burden on the intake department.

In 1934 the Fanily Service Organization case supervisor was loaned to the frunicipal Relief Bureau to study and reorganize the intake department. In 1934 the Family Service Organization participated in a self evaluation study made by the Fanily Welfare Association of America. In this study a definition of function was made: "The agency is now carrying families whose primary problens are incapacitation, mental and physical". In some instances the agency served as a correlating agency, helping the client to call upon the commuity resources he needed. 
Educational and vocational advice was offered. The agency also offered consultative services to lay individuals and to other agencies. The agency enphasized the protective aspects of their job. The study stressed the importance of the Fainily Service Organization's being the one farily agency in the community whose function and policies could be adjusted quickly to enable it to take care of any family or situation which another agency, because of rules and regulations, wight not be able to accept.

By 1935 care of the aged was already considered the responsibility of the public agency as was care of adult couples without children, ablebodied single ren and women, and the homeless. (The name of the Hunicipal Relief Bureau was changed to the lunicipal Bureau of Social sevvice, beptember 1, 1935.) In 2935 the family Gervice Organization transferred all chronic degendent and possible wother's fid families to the Hunicipal Bureau of Social Service. Worhs Progress Adiainistration work ws available in August 1935. Federal oirect relief funds were aiscontinued in Lecenber 1935. State funds for relief were available from December 1935 to April 1936 for the care of the unewployed. There was a serious Works Progress hidinistration cut. Although the Family Service Organization did not accept the unemployment relief burden or supplement on any case active with the riunicipal Bureau of Social Service, the Family Service Organization 
gave Iew services to the economically independent or borderline cases during this period. Miss Esther Taylor, executive secretary, makes an interesting observation that tine group of families norinally coining to the agency, as nembers of the economically independent group, on a service basis. were still applying but were forced by the depression into the relief group. vang had never been dependent on agencies before the depression.

In 1937 there was great suffering in Louisville due to the gaps in the relief program. Public funds were restricted and private funds could not meet the mass need. There was no direct relief for the able bodied unemployed, there was no temporary $r \in l i e f$ for the family where a member was eligible for Works Progress Administration certification or awaiting assignment. There was confusion on the part of the staff and the community as to the division of responsibility between the public and the private agency. (During the flood of 1937, the activities of the agency ceased temporarily in favor of Anerican Red Cross flood relief.)

A study of intake was made by tine agency from June to September 1937 in order to "evaluate intake policies, procedure, and agency function". Recomendations were made that cases should be acceptea on a case work basis, not categorically, that every applicant should be interviewed, that the interviewer be definite as to acceptance or rejection of a case, and that the interview should be more carefully recorded and should include a 
statement of the problem as seen by the woriker as distinguished from that as stated by the client. This study evidenced a growing concern about techniques and skills in the intake process.

1933 saw the final transfer of the major relief responsibility to the public agency when two hundred and seventy relief fanilies including all cases of incapacitation, chronic dependency, etc., were sent to the inunicipal Bureau of Social Service on April 1, 1938. This marked the discontinuance of public subsidy.

In May 1938, a brochure was prepared by Armentrout, a member of the Family Service Organization Board, and made available to citizens to further their acquaintance with the change in function of the agency, which was made possible when the Family Service Organization transferred the bulk of its relief cases to the innicipal Bureau of Social Service, the public agency. To quote froin Juage Richard Priest Dietzman's introduction in the pamphlet, "After some eight years of administering the public relief work of the City of Louisville, a task undertaken at the request of that municipality at a time when the depression suddenly burst upon us and our experienced personnel was imperatively neeảed, we now return to our original purposes and functions, the city having resumed the responsibility of public relief". The agency saw the need to reinterpret the work of the agency. There was confusion as to what the agency func- 
tion had becone. Some questioned the need for a private ramily agency while others saw the transier of relief responsibility as the opportunity for a greater challenge to the private agency.

1939 and 1940 were years of study, working toward a clearer definition of agency function. This meant a refinine of skills end a goining of new perspectives. In 1939 under the auspices of the Comunity Chest a study was macie of member agencies. The study of the Fanily Service Organization was made by two leaders in the family agency rield and a representative of the ramily Velfare Association of Anerica was present at all discussions. Agency function was derined in the study as follows: "The Family Service Organization gives advice and counsel on family problems to any family in Louisville who seeks such help. These services are available to families economically independent as well as to those economically dependent. The Family Service Organization is a non-sectarian organization rendering these services to a.ll families except Jewish ${ }^{1}$ (irrespective of religion, politics, race, or nationality)". The study further indicated that in addition to fauily services renaered, financial aid was extended in certain situations. Relief funds were used for those not eligible for public funds, according to prevailing public policies, to meet

I.

The Jewish Welfare Federation gives service to Jewish clients. 
temporary needs and to supplement existing incomes.

It was observed that increasingly funds would be used for special business and educational opportunities.

The study revealed that the agency was in the process of redefining its function. It was time to consider, study, learn, and interpret, a broadening of agency function. This would include more awareness of interpretation and use of the Family Service Organization by other agencies and the community. There was the need for reconsideration of intake procedures and the building up of a more effective method of intake. This included a suggested change in the intake set up whereby intake would be handled by the most skilled staff. There was an uneveness of job performance indicated. Definite recommendations were made as to an increased emphasis on an interpretative and educational program, as to services available through the agency and an extension and revision of case work services.

The recommendations made by the study were acted upon through the appointment of Committees of the Board of Directors and of the staff to study ways and means of making desired change in procedures. The agency has been taking forward strides and one of the purposes of this study is to attempt to evaluate this progress as it relates to a developing intake policy and to clearer definition of agency function operative at the intake desk. 
CHAPTER II

A DEVELOPING INTAKE PROCESS

IN THE FAMILY SERVICE ORGANIZATION 1884 - 1938 


\section{Chapter II}

A Developing Intake Process in Family Service Organization 1884 to 1938

The Charity Organization Society 1884 to 1907

The founders of the Louisville Charity Organization Society in 1884 did not see the organization as another relief organization but one to prevent duplication by acting as an investigator, free of charge, of all relief applicants to persons or societies. The agency sought to "promote and perfect people in almsgiving". I Its objects were:

1. to make employment the basis of relief

2. to prevent indiscriminate and duplicate relief giving

3. to prevent children growing up as paupers

4. to secure the community from imposition

5. to elevate the home life, health, and habits of the poor

6. to see that all deserving cases of destitution are properly relieved

7. to reduce vagrancy and puaperism and ascertain their true causes

In analyzing the application procedure one is impressed by the relatively unimportant place of the application process in these early years in terms of seeing the client as a person. The applicants were seen largely categorically. The term "client" is not used. The deci-

1. The Charity Organization Society Annual Report for 1902 . 
sion as to applicants' needs was left to the apparent dictates of the agency and contributors as to what was best for the applicant. The following statement clearly illustrates this philosophy:

A good physician when called to see a patient, does not introduce himself by asking the patient what he wants, and giving him what he asks. On the contrary, he questions carefully as to the symptoms of the trouble, previous living, mode of life, etc., and thus determines the cause and nature of the disease. He is then ready to prescribe the remedy, which he does not select simply because asked for or most agreeable to the patient. 1

The applicant was required to make a full personal statement as to his former residence, time of residence in the city, condition of the family, whether or not able to work, causes of aistress, names of former employers, names and residences of persons related to or able to verify statements, etc. All of this was written down on the application card and preserved as a part of the records of the district office. (These application cards were of paste board, eight inches by ten inches -"an extended list of questions".) (See Appendix III.) After the statement of the applicant was written out (refusal to give answers "indicated a fraud"), some such disposition was made as follows:

1. Non-resident applicants, if single men or boys 1.

Ninth Annual Report of the Central Council for the Year ending September 30, 1892. 
without families, were usually sent to the Wayfarer's Lodge for lodging. A deserted wife, a mother with young children, or a young girl was sent to the Home of the Friendless; put in charge of a "lady keeping boarders, who is known to be a kindly and proper person"; or sent home.

2. In the cases of the "resident poor", the district agent went to the home, verified statement as to whether there was sickness, lack of food, etc. The agent would also see references and obtain statements of rerification. When the investigation was complete and the applicant was found "worthy", his case was turned over to some individual, society, or church to meet the financial need. The charity Organization Society was divided into two districts, Eastern and Western; each had a district agent. Applicants were referred to the district in which they lived. The district agents received all applications. Cases were then brought before the district committees for a decision as to disposition. The district committees functioned in a diagnostic capacity. They were composed of lay members living in the district. If they felt the case clearly one of "helpless charity", it would be referred to the proper relief channel. If deemed unworthy or not requiring relief, the case would be dismissed. Vagrants were warned from the city. Idle 
men were put to work (see Report form of district committee, Apendix IV). This was a moralistic period. One comes across significant phrases in thinking of the Charity Organization Society period such as "deserving", "teach habits of industry and control", "people who sink low enough to receive alms", "honest poor" (those unemployed, able and ready to work, and those with insufficient work able and ready to do more, the partially crippled, and people with young children and unable to leave them), the "labor axiom", etc. We quote a paragraph from an agency case record of 1896:

The family members are veritable
tramps-- They have visited nearly
every large city, notably Washing-
ton City where they saw all of the
sights, the President included. --
The women are idle, Iazy, trifling,
immoral creatures; all filthy dirty
in person-- they are chronic beggars
-- they were warned that our city
workhouse was yawning for them.

As will be recalled, the Charity Organization Society in its original purpose was not to be a relief agency, but by 1889 the agency was administering emergency relief, giving shelter and food overnight for mothers and children or unprotected women. There was no other agency in the city at the time to give emergency aid. In 1893 a Benevolent Committee was functioning. Donations were made by private contributions (names of contributors were listed in the annual reports) and the

1.

Case no. 3438, September 1896. 
money was used as directed by the giver. By the time of the change in agency name to the Associated Charities in 1907 the agency had a major relief responsibility. In June 1893 the agency moved to its new quarters at $215 \mathrm{E}$. Walnut. In this year there was a financial panic and applications increased decidedly in 1894. In the winter of 1893 to 1894 the wood yard was started and a. women's work room set up. The annual report of 1895 spoke of the "new charity" which taught people that the true principle of charity is to help people to help themselves -- a cry in the wilderness at that time. By 1897 the agency expressed again in its annual report the belief that there was more general acceptance by the pubIic of the Charity Organization Society.

Because of the brevity of the application information recorded in the old case records and because there are so few records available previous to the early 1900's, it is not practical to analyze case material of the Charity Organization Society period. However, much of the information as to marital status, source of application, causes of need, and disposition of the cases is available through annual reports, and compilation of this material serves to give a fairly complete picture of the work of the Charity Organization Society in relation to intake, although again we point out that intake as a technique within itself was not recognized in this early period but was seen as the beginning of an investigation pro- 
cess. Some of this information is summarized in table form.

Table II (see next page) indicates the marital status of the new applicants for the years 1886 through 1907. (Figures for 1884, 1885, and 1898 through 1901 were not available.) In 1886 the largest group known were widows. The distinction in the statistics for 1886, 1887, and 1888 between married men and married women is not clear. In 1887 and 1888 the largest group of applicants were single men. This was no doubt because of the transient problem. From 1889 through 1897, married couples, widows, and single men comprise the major groups applying. 1902 through 1907 the majority applying were married couples. Agency reports during the Charity Organization Society period stress the problem of the widow and the transient.

Table III (see Appendix V) gives the source of the applications for the years 1891 through 1907. Referrals from benevolent individuals, city officials, and other agencies far surpass personal applications during this period. The small number of referrals from the churche is mentioned here and may be partially explained in that churches perhaps went directly to relief sources, as the agency advocated that church referrals not be investigated unless specifically requested by the church. Tables IV and V (see Appendix VI) give a picture of the disposition of cases for the years 1886 through 
Table II

Condition When First Known of Cases New during the Year according to Marital Status 1886 to 1907

\begin{tabular}{|c|c|c|c|c|c|c|c|c|c|c|c|c|c|c|c|c|c|c|}
\hline Marital status & 1886 & 87 & 88 & 89 & 90 & 91 & 92 & 93 & 94 & 95 & 96 & 971 & 1202 & 03 & 04 & 05 & 06 & 07 \\
\hline Married Men & 179 & 141 & 150 & & & & & & & & & & & & & & & \\
\hline Married Women & 277 & 111 & 16.5 & & & & & & & & & & & & & & & \\
\hline Married Couple & & & & 158 & 147 & 194 & 286 & 34] & 645 & 193 & 138 & 118 & 83 & 58 & 61 & 32 & 31 & 50 \\
\hline Single Men & 187 & 233 & 215 & 126 & 109 & 117 & 90 & 87 & 73 & 22 & 16 & 18 & 4 & 3. & 2 & 1 & & \\
\hline Single Women & 62 & 68 & 76 & 43 & 22 & 31 & 32 & 40 & 55 & 28 & 12 & 10 & 3 & 1 & 1 & 4 & & 5 \\
\hline Widows & 310 & 106 & 49 & 92 & 80 & 86 & 144 & 205 & 247 & 72 & 56 & 32 & 11 & 17 & 18 & 8 & 9 & 10 \\
\hline Deserted Wires & 62 & 44 & 178 & 30 & 32 & 25 & 40 & 60 & 80 & 34 & 26 & 27 & 13 & 23 & 5 & 5 & 9 & 15 \\
\hline Widowers & 77 & 59 & 2 & 42 & 44 & 49 & 54 & 25 & 30 & 10 & 7 & 7 & 3 & 1 & & & & \\
\hline $\begin{array}{l}\text { Deserted Husbands } \\
\text { Orphaned or aban- } \\
\text { doned Children }\end{array}$ & 8 & 7 & 58 & & & 9 & 6 & 5 & 1 & & & & & & & & & 1 \\
\hline $\begin{array}{l}\text { Divorced or sep- } \\
\text { arated (Iegaliy) }\end{array}$ & & & & & & 2 & 10 & 3 & 4 & & & & & & & & & 1 \\
\hline Total & 1162 & 769 & 873 & 491 & 434 & 514 & 669 & 766 & 135 & 359 & 256 & 212 & 120 & 93 & 105 & 50 & 46 & 76 \\
\hline
\end{tabular}


1907. Consistent information for other years is not available but figures for these years serve as an ilIustration. The class distinctions here are interesting from the point of view of their indicating the strong judgemental, moralistic outlook and curative emphasis. The aged, the incurable, the orphans, all charged now to public responsibility, were seen as definite responsibility for whom the gency should seek help. One sees the early Charity Organization Society tenet that relief is detrimental. Work is the answer. A large group (24\% to $31 \%$ of total applicants) was deemed unworthy because they were "vicious", "permanently shiftless", or intemperate. This group was held not to be the responsibility of the agency or other charitable sources but perhaps needing indoor relief. Those applicants economically secure or who could turn to relatives were considered with the "unworthy". Visitation and advice as service, first evident in statistics for 1891 although limited from the point of view of numbers, seems to mark the beginning of a more definite service program not based on the investigation process. 


\section{The Associated Charities}

1907 to 1921

In 1907 the agency name was changed to the Associated Charities. As the Charity Organization Society period was characterized as curative in emphasis, the Associated Charities period stressed prevention. During this period social workers were becoming conscious of techniques and developing skills. From 1910 on, when the first trained executive came to the agency, the actual work of the agency was carried by paid staff members. This period from 1907 to 1921 saw the development of the case method of individual approach. Mary Richmond in her Social Diagnosis published in 1917 stressed the underlying philosophy of Individual differences. Her definition of social diagnosis was "the attempt to make as exact a definition as possible of the situation and personality of a human being in some social need". In her book What Is Social Case Work? Mary Richmond stressed case work "policies" or techniques, "not officialism but encouragement, stimulation, participation of the client in plans". She spoke of what we now call relationship in terms of "natural human friendliness" and the worker showing interest, sincerity, directness, and openmindedness in relation to those coming to her for help. InfIuences of the wider developments were evident in the Associated Charities. 1910 to 1917 was a period of growth. An interpretive letter written in 1911 for pub- 
licity emphasizes the preventive goal: "A charity which is simply palliative is not adequate. -.- the true function of this organization is to build up families to be strong and useful members of the community".

To give a picture of the developing work of the agency, situations faced and met by the agency are mentioned as they influenced intake policies. In 1912 the Associated Charities used five thousand five hundred and fiftytwo dollars and twenty-eight cents $(\$ 5,552.28)$ for relief, more than double the amount for the previous year. Three new workers were employed. Hiss Harriet Anderson, superintendent, in her annual report for the year pled for the opportunity to do more preventive work. In 1913 the problem of continued relief to families who could not care for themselves was paramount. Hothers' pensions were available in many states but the entire responsibility fell to the Associated Charities in Louisville. In 1914, four hundred and seventy widows with children and two hundred and sixtyseven deserted wives received assistance, and these two groups were described as the greatest drain on relief funds. Continued relief was not given except where the breadwinner was dead or disabled.

During 1914 a Legal Aid Committee was formed by the Associated Charities Board. (Mr. Grover Sales, a board member, was actire on this committee and was a member of a special committee that worked in cooperation with the Jefferson County Bar Association to establish the indepen- 
dent agency of the Legal Aid Society in 1920 and served as its first president.) An applicant for legal service from the legal committee of the Associated Charities must have been unable to have a private attorney. The committee could not handle divorce cases but could attempt to reconcile differences. Briefly reviewed, problems presented and services offered were as follows:

1. advice - legal and friendly

2. alimony -- investigation and advice

3. crimes against children -- investigation and report

4. delinquency and dependency of children -- investigation and cooperation with Juvenile Court

5. non-support -- investigation and report. This appears to have been primarily an investigatory service.

The directors of the Associated Charities in the president's report of November 1914 indicated their belief that money used in direct relief was well spent if the condition of the families was permanently improved. If no closer source existed, the Associated Charities took care of the family in need. It was pointed out that in 1907 the Associated Charities used practically all funds for investigation. It was believed then that when relief was dispensed in plenty it was harmful to the client. Mr. Barker, (M.S.). the president, stated the fallacy of this belief had been proved. Relief work when inadequately done had necessitated breaking up families that could have been saved; more people had died of tuberculosis, etc., because they were poprly housed and fed. The effort of Associated Charities was to 
preserve the family and the best influences in the home. Mr. Barker characterized Associated Charities as a "distributing station of philanthropic effort", and stated that 1914 was the busiest year in the history of the organization. The developing concept of adequate relief was somewhat of a revolutionary idea.

In 1915 there was an increase of families known to the agency from twenty-seven hundred and twenty-four $(2,724)$ to forty-four hundred and forty-two $(4,442)$. This brought new problems. The use of the Associated Charities as a "service station" was increasing. Organizations and individuals using the records, visitors, and clearing house opportunities increased. Forty-two hundred and eighteen $(4,218)$ applications for investigation were made by other organizations in the city. Amid this increase in work there was the cry for doing constructive work.

1918 with its unsettled war conditions intensified service needs. Beginning January 1, 1918, the income of the Associated Charities was received principally through the Louisville Federation of Social Agencies (later the Welfare League and now the Community Chest). The Wayfarer's Lodge was closed in 1918 because of lack of applicants for care. 1918 was a busy year for the Associated Charities, as has been indicated in a previous chapter. The district committees, advisory lay groups, were again formed (three white and one colored). Study classes were organized for staff members. 
Mr. Homer Wickenden, superintendent, in his annual report in 1919 described the word "charity" as repugnant. Of a total of 1571 families, $23 \%$ or less than one in four required financial assistance. $77 \%$ received personal "service". The agency was hoping the quality of work would improve in 1920 with emphasis on service. The idea of the client group as made up of individuals and not as an entity outside of society was accepted by the agency. In closing his report, Mr. Wickenden quotes Tolstoy concerning contact with the poor:

Strange to say, I now for the first
time understood clearly that the bus-
iness I had undertaken cannot consist
merely in feeding and clothing a
thousand people as one feeds and
drives under shelter a thousand sheep,
but that it must consist in doing them
good. And I understand that each of
these thousand people was a human be-
ing with a past; and with passions,
temptations, and errors, and thoughts
like my own, and was such a man as
myself.

By 1920 psychological and psychoanalytical contributions were being introduced into the developing field of social work. Relationship was described in terms of "rapport" and "transference" with hesitancy as to just how this might be incorporated in the new development of the new social work profession.

An analysis of record material is interesting. I There is a great similarity in recording of the client's first contact with the agency, material differing primarI.

See application card used by the Associated Charities, Appendix VII. 
ily as to factual material and as to who referred the case or applied for help. The interviews were consistently brief with entries anywhere from a two or three line entry to a longer paragraph. Because of this similarity schedules of sixty-one cases dating from 1907 to 1921 provide a random sample. Compilation of statistical material although having little meaning as far as totals are concerned may be considered indicative of certain characteristics. Factual information is lacking in the first contacts. For example, of the sixty-one cases studied, thirty-one contained no information as to residence of the client, thirty-two contained no information as to religion, and fifteen as to size of the family. (See table VI, Appendix VIII)

It is interesting to comment here that in reading records there was no mention in the interview of race. The agency had been assisting colored families since 1905, but the first colored worker was not emplyed until 1917.

Table VII, Appendix VIII, shows the source of the application. Only eighteen of the sixty-one cases studied came by personal application. Twenty-four were referred by individuals and nineteen by other agencies. Tables VIII and IX, Appendix IX, indicate that the largest group of applicants were white matried couples; the next largest group were white widows. The small number of divorced applicants is noted. The number of old and recurrent cases seems unusually small. Table $X$, Appendix $X$, indicates that of the sixtyone applicants very little was known of the financial status at the time the application was received. 
In the families needing maintenance, five were in need because of unemployment, one because of physical incapacitation of the breadwinner, two because of illness of the head of the family and two because the man was in jail or the workhouse. Those needing supplementary relief had inadequate incomes because of inadequate employment and of the five one was unknown. Incomes of those referred who had inadequate incomes were not listed consistently enough to give a picture of the situation.

In relation to the mechanics involved in the intake process, one has no picture of the procedure apart from that described in agency reports. The record material usually indicated that the case had been registered and, after 1914, Social Service Exchange registrations were usually entered with the identifying information. Apparently the registration was consistently made. (See table XI, Appendix X.) Apparently the agency did not make much use of other agency record material. The records read contain no information as to who saw the client at the point of application or who received referral calls. We know that the district agents or supervisors did not continue to take all applications and that this was taken over by clerical workers, but it is not clear from record material or agency reports just what changes were made and when they were made.

There is evidence that during this period stress was placed on referral requests from other agencies and individuals rather than on personal application. Throughout 
the Associated Charities period there is little picture of the client at the point of intake as recorded in case material. The intake contact with the client was factual and incomplete, mostly a statement of the present situation in the home. The request made was not always clear, but the need for work and relief was usually stated or implied.Other client requests involved requests for boarding care for children, assistance while the breadwinner was in jail or in prison, help with an eviction, a night's lodging, transportation.

Referral requests were made Iargely on the basis of the agency investigating various conditions or of the family being destitute, and largely set the pace for activity. The cases referred seemed to involve primarily need for environmental readjustments, health care, financial assistance, non-support, drinking, insufficient income, and later help with specific needs such as leg braces, glasses, artificial leg, etc. Some referral requests were vaguely indicating other needs such as "woman nervous and cannot work", "needs help and advice". Then, as previously indicated, there were the requests for investigation for admittance to the Home of the Aged, Home of the Incurables, helping a family so a member could go to Waverly Hills, etc. There was only rarely clarification in the record as to what the client or the worker saw as the problem involved in the need for help except in the broad, categorical, impersonal terms of old age, insufficient earnings, bad housing, 
chronic physical disability, incoinpetence, intemperance, non-support, "a widow", a "deserted woman", and others.

In 1919 compiled statistics listed chief problems brought to the agency as follows:

$\begin{array}{lr}\text { physical } & 597 \\ \text { mental } & 61 \\ \text { moral } & 307 \\ \text { industrial } & 575 \\ \text { unknown } & \frac{31}{1571}\end{array}$

There is no recording of agreement made between client and worker or between worker and referral source at the point of intake. There is no indication of what the agency might do or what the applicant might be able to do for himself. There was seldom an understanding about plans for the next contact although a visit was usually implied. It was in the first interview in the home that detailed information was secured but again there was little mutual participation. Not until 1917 with the advent of the crystallization as embodied in Miss Richmond's philosophy, was there generally the beginning of seeing the applicant as a person. Still the process was centered in the first interview and not at the point when the agency first received the application.

It is difficult to analyze the activity of the worker and the client as so much of the recorded material of this period is factual and situational. There was no detailed recording as we today think in terms of process recording in which we are aware of what the client says, what the wor- 
ker says and the mutual participation. However there are certain clues of a factual nature. One is aware of the worker's activity in doing things. She verified information such as telephoning employers. She was direct and was apt to impose a "Do as I say" attitude. She would tell the applicant of job prospects and advise him to get out and get a job. Emergency help would at times be given at the point of intake -- a night's lodging or "meal tickets". She was apt to be somewhat judgemental as in one specific instance where the client, a widow, wanted to get work and relatives would take care of her children while she worked. The worker and the referral source were prone to consider the woman somewhat neglectful and told her she should stay at home with the children. The worker saw what she thought the best plan for the client. The social worker had not yet learned to work with the client and to let him have a part in deciding what help he needed and wanted and what goals he was working toward. The agency was attempting to be preventive in emphasis but approached this through trying to treat symptoms of trouble rather than seeking out the cause. The agency was aware of this and in 1921 and 1922 stressed getting at the cause of the trouble.

One has the sense of the worker's authoritative approach and little understanding of "resistance, hostility", and other reactions that today are an essential part of our basic understanding of what it means to ask for help. The worker was inclined to brand resistance and hostility 
as uncooperativeness or willful desire to deceive. The worker was not secure enough in her new and developing profession to be able to use encouragement and not officialism and to stimulate the client to participate in plans. The agency evidently was facing a change in emphasis and techniques by 1920 and this change in philosophy was reflected in intake policies. The change of agency name from the Associated Charities to the Family Service Organization in 1921 marks the beginning of another developmental period in the work of the Family Service Organization. 


\section{The Family Service Organization}

1921 to 1929

In the annual report of the Welfare League and its member organizations for January 1, 1921 to December 31, 1921, the Family Service Organization report begins with the following statement: "First meet promptly the immediate need; then try carefully and sympathetically to find and remove the cause of that need". 1 The above is qualified in terms of the second part being of far greater importance from the standpoint of lasting results. The immediate need may be satisfied with "material relief -- food, fuel, clothing or money. But the family with a widowed or deserted mother, with an incapacitated or intemperate or non-supporting father; the family which has fallen below the normal standard of living because of illness, intemperance, immorality, or incapacity to cope with the conditions of life -- such a family would be poorly served by the mere repeated handing out of material relief with no attempt to help it in the solution of its problems".2

"Because to many people the word 'charity' has come to mean merely the giving of alms without the accompanying kindly service, the Associated Charities changed its name last December (1920) to the Family Service Organization with emphasis thus placed upon the 'Service' instead of upon the word 'Charity', it is hoped that those self-res-

1. Annual report of the Welfare League, Jan. 1, I921 to Dec.31, 2 . $1921, \mathrm{p} .18$.

Ibid. 
pecting families which are struggling to keep above the border line, but which are suffering from social ills complicated by personal difficulties, will no longer hesitate to apply for help". I

of a total of twenty-four hundred and fifty-three $(2,453)$ families cared for in 1921, an increase of eight hundred and forty (840) over the year 1920, only eight hundred and three (803) required material aid. The others needed many other kinds of service the cost of which lay in the salary and service of the worker. Some of the services listed were securing medical attention, hospital or nursing care for the sick, finding employment, helping to keep children in school, encouraging an overburdened motiner and telling her how to plan menus and to manage her house on a limited income, and forcing deserting and non-supporting fathers to assume their responsibilities. Each of the nine workers was carrying an average of one hundred cases. There was a Home Economist on the staff' beginning June 1921 who taught household management and the planning and preparing of meals. An emergency worker was also added to the staff during the year to care for the five hundred and ninety-nine (599) transients who applied for aid (averaging sixty-five (65) cases a month). These transients were given food and lodging and help in finding employment or returned to their homes if plans could be made for them. The Legal Committee helped seventy-five (75) families during the year.

1.

1921 report of the Welfare League, ibid. 
The history of the Family Service Urganization can be traced not only by chronological events but in terms of its developing case work philosophy and techniques. The broad Family Service Organization trends up to the beginning 1920's parallel those elucidated in the preface to the Proceedings of the National Conference of Social Work held in Washington in 1923, celebrating the fiftieth anniversary of this body. Decades of development were characterized as follows: the first ten years emphasized statistics; the second, humane care and correction of abuses and neglect; the third, a transition from care to cure; the fourth, prevention "a profession of faith" (rather) than as a working program; and the final decade to 1923 as prevention "a fruitful reality". At that same conference iliss Gordon Hamilton (then with the New York Charity Organization Society) in her paper on "Some Changes in Social Case Work" referred to Miss Richmond's definition of social case work: "Social case work consists of those processes which develop personality through adjustments, consciously effected, individual by individual, between men and their social environment", and points out that the common tools for practicing this case work were "loyalty, endurance, fearlessness, and case work intentions that far outran the hope of immediate accomplishment". Early case work was helping "poverty", not people.

A widow was a fact. A deserter was a fact, etc. Employment, intemperance, shiftlessness, mendicancy were facts. Fashions varied and different facts were faced one 
at a time, economic, tuberculosis, housing, and after the war, venereal disease and sex. Miss Hamilton does not wish to disregard facts but would add to these facts the effect of the dynamic discoveries in mental hygiene and the opening up of new areas of treatment.

Early treatment was objective and corrective rather than subjective and interpretive. The worker dealt with situations rather than personality. As the social case worker inherited his field from philanthropy the first emphasis was economic with a series of "pills" for treatment. The "pill for poverty was work", the "pill for desertion was the law or the workhouse", the "pill for a kind of chronic dependency was removing people to their native locality", the "pill for unmarried workers was a place at service", the pill for broken homes and behavior problems was the institution, etc. The new technique Hiss Hamilton saw as emphasis on facts along with conditioning factors. We are conscious of the new awareness of case records and their becoming more and more "text books of case work methodology". Miss Hamilton closed her paper with a plea for more scientific diagnosis and evaluation and the integration -- of past and present. "The sin of casework today is pride". "The equipment of a case worker is dust and ashes unless he has the disposition of both scientist and disciple".

The Family Service Organization was stressing prevention during this period along with the movement toward governmental support of certain groups of families. Special 
training for social workers was being required. There was a redefinition of agency function to stress the family as a whole. Family work was basic in the trencd toward reducing and preventing poverty and disease and preventing family breakdown.

In 1923, Mr. Iinton B. Swift, general secretary of the Family Service Organization at that time, in a report called "A Startling Summary", called attention to Louisville's lack of facilities for the care of dependent drug addicts, the feebleminded, epileptics, chronic invalids, convalescents, the aged and infirm, etc. "The Family Service Organization must therefore, to the best of its ability, do the work which should be done by ---- institutions as well as supply the lack of a state allowance for widows and deserted mothers and the usual city relief department". On September 15, 1923, the Central Council proposed the following resolution:

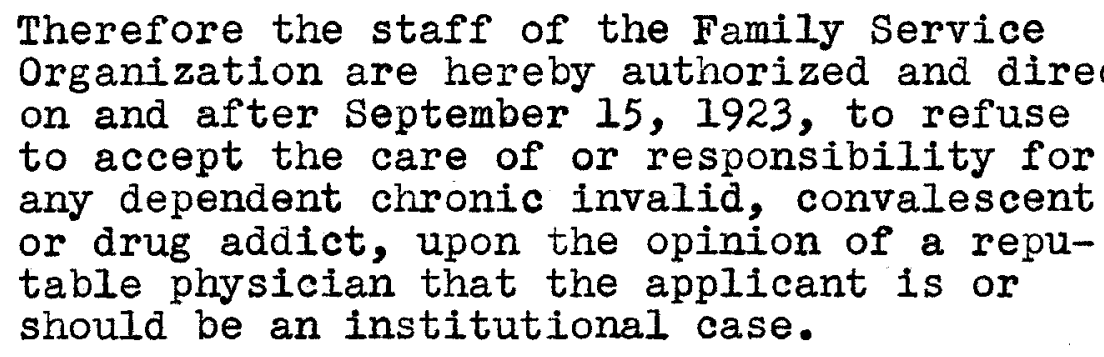

Action was not taken on the resolution but significance lay in this being the first mention of closing intake to families who in other cities were cared for in public assistance programs.

"Salient social needs" were listed as follows in the report of the President of the Board of Directors on 
March 19, 1926:

1. Adequate resources for the chronically ill, for concalescent care, for care of the feebleminded, all of which are an undue burden on the private agency •

2. Provision for the care of aged married couples at the Home for the Aged and Infirm.

3. A free employment bureau (a Family Service Organization employment bureau was opened in February 1927).

4. Meeting the problem of the loan shark and instalment buying house.

5. Need for Mothers' Aid.

6. Need for public relief responsibility.

7. Need for more adequate court procedure in dealing with desertion and non-support cases.

The agency continued its focus on the need of a public agency and in 1929 an ordinance was passed establishing the Unemployment Relief Bureau. Louisville had no form of mothers' aid until 1928. Under state law it was not mandatory but was administered in Jefferson County through the Louisville and Jefferson County Children's Home.

From 1924 to 1929 there was a gradual increase in work during which time the total number of cases carried was almost doubled. There was likewise an increasing emphasis on service although the agency was still the overflow for other agencies. 
Intake had been occupying an insignificant place in terms of technique or as an integral part of relationship with a family. Applications were taken largely by clerical workers and the first interview in the home was thought of as the significant beginning of contact. The complicated processes surrounding a request for help had not been defined in practice. How a client came to the agency, what he wanted, what the initial contact meant had not been considered. Reports and interpretive statements stressed the numbers of people applying and the category to which they belonged. Intake was not considered a key stone to further relationship. Skills stressed in later contacts were not seen as applying to the intake process. Therefore, the placing of a case worker at the application desk beginning June 1, 1925, indicated a step forward. In table XII (Appendix XI) showing the staff set up from 1921 to 1929 an application worker is listed, beginning in 1923. The worker at the intake desk was not termed a trained person until the change in set up in 1925. In the annual report of that year by Mr. Paul Benjamin, general secretary, he stated:

$$
\begin{aligned}
& \text { One of the best case workers is being } \\
& \text { transferred to the application and in- } \\
& \text { formation desk. Since this is the place } \\
& \text { where we meet the public, it is necessary } \\
& \text { to have as expert service there as pos- } \\
& \text { sible. Further such a worker will mater- } \\
& \text { ially save the time of other visitors by } \\
& \text { being able to handle many thing at the } \\
& \text { source. }
\end{aligned}
$$

This statement seems indicative in its emphasis on the trained worker's being at the application desk because of 
need of expert service to meet the public and to save the visitors' time. How different, as we will note later, from the present philosophy of the application process centering about the client. This statement excludes the client, leaving the community and the worker instead of the three vital elements -- client - worker - community.

Unfortunately, the trained worker placed at the application desk was almost immediately shifted to another specialized job in the agency and a worker with only a brief experience as a case worker took over this assignment. She was not considered a trained worker but her calmness and poise undoubtedly helped her to face the pressure of the job when the important thing was to see as many people as possible each day. It is significant however that skilled service was not available at the intake desk as planned. Annual reports and reports of the general secretary for the year 1926 indicate a more careful sifting process at the intake desk. In a study of applications in one district for the month of March 1926, of one hundred and four (104) applications, forty were accepted because of illness, three because of unemployment, thirteen because of desertion and non-support, and ten because of old age. Service reports were listing problems under the following headings: industrial, economic, physical, mental and personality, the latter new with the agency in the beginning $1920^{\prime} \mathrm{s}$.

The consensus of the annual reports, of the reports 
of the general secretary, board minutes, etc., indicates that the years from 1925 to 1929 were regarded as years of growth for the agency and a growing professional consciousness. There was an emphasis on services not involving relief and an attempt to be articulate about these services. In a report of the case supervisor for the year 1925 the question is asked:

What did service to families mean? --- a source of coal and groceries only, or did it mean a source of real helpfulness in a family crisis, a friend with sympathetic understanding who would plan with them, and who would help carry out the plan even though it took months, perhaps, or even years?

The following figures comparing numbers of relief and service only cases were given for the year 1925:

\begin{tabular}{|l|l|l|l|l|l|l|l|l|l|l|l|l|}
\hline $\begin{array}{l}\text { Service Clas } \\
\text { Sification }\end{array}$ & Jan & Feb & Mar & Apr & May & Jun & JuI & Aug & Sep & Oct & Nor & Dec \\
\hline Relief & 471 & 435 & 403 & 286 & 249 & 232 & 225 & 203 & 206 & 248 & 235 & 313 \\
\hline Service only & 364 & 445 & 455 & 482 & 450 & 335 & 280 & 229 & 236 & 226 & 220 & 262 \\
\hline
\end{tabular}

"The clinic, the school, the job, the club, are the tools the caseworker uses, but the results are so intangible that mere numbers convey nothing of the work she really does". In the report of the general secretary of 1926 the work of the family visitor is described as "development of personality in the individuals who make up the family she serves."

This same report outlined limitations of applications. No applications were to be accepted by anonymous 
referral except if referred through the newspaper. No applications would be accepted through persons outside the family who had not first been assured of the family's willingness to have assistance. No applications would be accepted of families living in Louisville less than a year if they could be cared for at their place of residence and they had refused such care. Work in the county was to be eliminated on April 1, 1925 (this included the large Camp Taylor area), and finally the services of the home economist were to be dropped.

These limitations seem significant in several respects. They mark a definite beginning of setting limits and a trend toward defining function. The first two limitations stated seem to indicate a beginning of self-determination of a client -- at least he was to be aware that he was being referred. Here was stated also limitation with respect to boundaries, specifying that no county cases would be accepted.

1926, 1927, and 1928 saw the rise of unemployment. Because of inadequate relief to meet the increasing demand the Community Chest drive was eight-one thousand dollars $(\$ 81,000)$ short of its goal in 1927. As the Family Service Organization had two hundred more applications in January 1927 than in January 1926, again there were limitations imposed at the point of intake. In March 1927, Helen P. Story, acting case supervisor, made some suggestions to meet the emergency situation. These suggestions throw light 
on the application procedure (see application form, Appendix XII). Specific intake instructions were as follows:

1. Widows and their children and nonsupport cases should not be accepted as allowance cases until there has been the most careful scrutiny to see whether or not it will be best to keep the families together or to break them up. Such cases will not become allowance cases without the approval of both the district and the case supervisor. 2 . Women who wish to place their children shall be permitted to do so unless there are flagrant reasons why tinis procedure is unnecessary.

With regard to the general case load, withdrawal of relief from "non-cooperative" cases was advised. Investigation was stressed. Each district was urged to develop resources for the employment of clients.

A later memorandum from the general secretary (July 1927) concerning "Intake and front desk" further clarified procedure and limitations:

1. Handle all matters with dispatch. Telegrams, telephone calls, and letters should be taken care of immediately. Don't leave anything open that can be settled now. Make your first contact count for all that is in it.

2 . Sift out cases at the point of application.

3. Suggest to people referring families that they take up with families whether or not they want the service of the society. 4. When a family applies for the first time, Mrs. Walker (intake worker) should see if it would be possible for them to get along until the next day.

5. When a case comes, if after clearing with Social Service Exchange it is found to have been active, read the record before the case is accepted.

"Everything possible should be referred to some other agen- 
cy". After legal residence was established no relief other than transportation was to be given. Women were to be asked to help support the family even though it might be best for the children for her to stay home. No new long time allowance families were to be accepted without the approval of the case supervisor. "Bringing out family problems" was left to the worker in the first interview.

All service cases not falling into one of the three following classifications were to be "minor service" cases and placed in the closed file, keeping a record of the source of the application and the status of the amn. Work with "this type of case should be thorough. Advice should be given the family as to all possible ways out of their difficulty and a careful explanation as to why requested service cannot be given". The three exceptions to be accepted were:

1. Investigations for the Home of the Aged and Infirm.

2. Acute situations where aged or chronically ill need immediate care.

3. Situations where major element is that of neglect of children.

New or reopened cases were to be dictated within twenty-four hours following the interview.

By Jamuary 1929, the Family Service Organization had reached a new conception of family case work, with an increased concern for the integrity of the family. Mr. Benjamin stated in his annual report of January 25, 1929, that the agency was not seeing people en masse but as individuals -was looking within -- not without - a new faith in possi- 
bilities in human beings. The social case worker "wishes to know the tensions and stresses and strains within the family group; she is sensitive to the strength of real family life".

The worker is also coming to the real-
ization that there must be a partici-
pation upon the part of the individu-
als or family with whom she is working
if pliable strength is to be developed.
Entering with understanding into the
lives of other folks and sharing with
them their experiences is a rich and a
rare thing.

Further he stated, "we must not stress only individual needs -- an over emphasis on the individual has led us somewhat astray. Case work is social -- let the layman in". "The agency did not exist to provide simply shelter, food, and clothing" but its prime purpose was to "understand human beings and to help them return such individuals to a normal place in community life. Relief is but one means to this -- we are medicine, jobs for the unemployed, and rest for a worn out mother". The agency was swinging away from an emphasis on relief and stressing the "development of wholesome family Iife".

A comparative report for the years 1925 to 1929 stressed the agency's consolidating itself in the community with its function of family rehabilitation. Specific recommendations were made in terms of need for a public welfare department, a free employment bureau, county family social work, more district offices, (Portland district office established January 1927), a more adequate staff, 
need for another full time application worker, more adequate interviewing space, better waiting room facilities, etc.

One is impressed in reading actual case material of this period, with how little the many outside influences and developments of case work within the agency are reflected in the recording of application material. The application contact continues to be brief and largely situational in content. There is every indication however, in agency reports and in recording of first interviews at the time that the worker visited in the home after the case had been accepted, that between the years 1925 to 1929 the services offered by the agency reached a peak in terms of constructive treatment which was not again attained until the major relief responsibilities were transferred to the public agency in 1935 to 1938. There was a weighing of the client's assets and liabilities and emphasis on diagnosis and treatment plans. These techniques and processes were not evident at the point of application. We recall that in June of 1925 according to report of the general secretary, a skilled worker was placed at the intake and information desk. One would assume that there would be some change in the intake process. One's observation, based on the reading and analyzing of a random sampling of twenty-six application interviews of major care acceptance for the years 1921 to 1925, and fifty-three application interviews for the years 1925 through 1929 would be that all of the ap- 
plication interviews were primarily factual in character. The distinguishing factor in the period from 1925 through 1929 seemed to be the awareness, at least in a beginning sense, of two people participating, with the emphasis definitely on the worker and what she did. (In the period 1921 to 1925 as in earlier periods one found mostly a statement of fact as to what the need was -- food, coal, work, etc., and on the face sheet in the record the worker would check some general problem such as subnormal mentality, insufficient income, unemployment, man's drinking, old age, illiteracy, illness, etc.) The worker was seen getting more information. She recorded the situation as stated by the client in terms of need and usually a limited picture of the cause of need. For instance, if the client stated he was unemployed, there was a statement as to why he was out of work. In other interviews there were indications of other difficulties but in general relief need was explored and discussion of other problems was left to the worker carrying the case. One applicant asked for help in getting work as he was laid off from a place he had worked for twelve years. The intake worker accepted the case but left clarification of the problem to the worker carrying the case. In another application interview the man requests rellef. The worker elaborates by relating the "client's nervous condition" and his being given a three months leave of absence from his job to do something about his health. The intake process stopped at this point -- statement of the situation and 
some recording indicating that the worker saw implications for the agency's being able to offer help. There was seldom offer of any specific service in relation to the need presented. There was no statement as to why the case was accepted or whether an understanding was reached between the worker and the client. Plans for the next contact were sketchy. In 1925 of a total of fourteen hundred and twentyeight $(1,428)$ applications, $43.4 \%$ were personal applications, $29.1 \%$ were referred by interested individuals, $17 \%$ were referred by other social agencies, $6.5 \%$ were referred by police or other public officials, and $2 \%$ were referred by churches. The higher percentage of personal applications would indicate a developing emphasis on the client making his own application. In 1926 the proportion of personal applications increased in relation to referrals by individuals and other agencies.

Tables XIII to XVII (see Appendices XIII, XIV, and XV) give statistics of cases read for the period from 1921 to 1929 with regard to color, religion, residence, number of children, source of intake, status of application, family status, financial status, and classification as to why the family requested supplementary or maintenance help. of this sample of cases read, the largest group where religion was listed were protestant and were residents of the city. The families applying were small in size; those having one or two children were in predominance. Of the seventy-nine cases read, thirty-five came by personal application, thir- 
ty were referred by individuals, and fourteen by other agencies. Table XV shows the status of the applications in the sample read. Fifty-two of the seventy-nine cases were new to the agency, twenty-two had been known to the agency previous to the year in which they were applying, four had been known to the agency previously within the same year, and in one case status of the application was unknown.

Table XVI indicates that there was a predominance of married couples applying, the next largest group of applicants being in the deserted and separated group, then widows, widowers, and divorced women, and a small number of single men, single women, and unmarried mothers.

Table XVII a, b, $c, d, e$, give a picture of the financial status of the applicants during the period from 1921 to 1929. Of the seventy-nine applications in only seven were the families known to be economically independent. (This may be somewhat higher in that in twenty-one cases financial status was unknown.) Thirteen of the seventy-nine requested supplementary assistance primarily because of insufficient income and thirty-eight requested maintenance relief. Chief causes of need for maintenance relief were unemployment, illness, desertion, and physical incapacitation.

Application procedure included clearing with the Social Service Exchange although this procedure was not often evident from the application contact and it was not 
indicated in most instances whether other agency clearings were checked. Iikewise reading of a previous Family Service Organization record on a family was most often not indicated. Apparently the appointment system was not used but a client was seen when he came to the office. (See table XVIII, Appendix XVI).

From 1921 to 1925 in the cases read, the majority of the clients were first seen in the home by the worker to whom the case had been assigned. One cllent was seen in the office by the night clerk and who saw the other applicants was not indicated. Apparently clerical workers took most of the applications previous to 1925. In the period from 1925 to 1929 in twelve of the fifty-three cases read the client was first seen when a visit was made to the home. of the applications taken in the office one was taken by the worker on duty on Saturday afternoon, two by a worker who did not continue to carry the case, two by the Intake Secretary and in twenty-nine interviews it was not indicated who saw the client, but apparently these clients were seen by the Intake Secretary. (See table XIX, Appendix XVI.)

This sample of cases, fairly typical of the entire application material during this period, gives a representative statistical picture of the agency functioning at the point of intake. 
The Family Service Organization

1930 to 1938

By the end of 1929 there was a new emphasis on economics and politics because of the impetus of the depression, the failure of industry, and unemployment. Unemployment was seen not as a moral failure but as a discrepancy between individual capacity and environmental demand. Rehabilitation was seen not as a cure but as a restoring to balance. For the agency this was a period of gradual transfer of groups of cases to the public agency. In 1930 an emergency department was established to meet the heavy unemployment relief demands. All unemployment cases were handled in this department and "intensive work" was done with families coming to the agency for reasons "other than that of the industrial depression". 1 In March 1930 the agency discontinued service to all except relief cases. For eight months families were turned away. The agency was vague and confused as to function. It was realized that the private agency could not care for all who needed case work and attempts were made to define the agency's province as "the family", implying not the adult group but parents and children. Care for the adult, the unemployed, and the aged was seen as public responsibility.

I.

The Family Service Organization Annual Report for 1930. 
In a study of one hundred rejected families made by an agency worker in 1930 the following needs emerged:

1. The need of a social worker trained

to take applications so that decisions

in accepting families can be made on a case work basis.

2. The need for a more adequately

trained staff, and funds to care for familles making application for service or relief or for both.

3. Adequate facilities or agencies to meet the needs of adult and aged groups for which a private family agency cannot be responsible. 1

In 1930 there were two full time workers and a part time worker at the application desk. In 1932 no relief was to be given until the worker called in the home. In 1933 the agency policy was, in as far as possible, to refer all able bodied men to the Municipal Relief Bureau for work on the work relief program. The Family Service Organization assumed the responsibility for case work for some of these families, and was responsible for the unemployed who did not fit into the work relief program.

In an agency self evaluation study made under the guidance of the Family Welfare Association of America in 1934, the question on methods of selection of intake was answered as follows: "our intake policy for the past year has been one of flexibility. We fit into the community picture of intake as worked out by our inter-agency groupn. 2

1. Harriet Tynes, "Some of the Facts Found by a Study of 100 2. Families Rejected by the F. S. O. in 1930". 1935 Annual Report. 
In a statement made by this group, the Family Service Organization intake policy was condensed in the following words: "Resident families with dependent children where unemployment is not a major problem are accepted by the Family Service Organization". This was further clarified by Miss Esther Taylor, executive secretary of the Family Service Organization, as she pointed out the attempt to select cases on the basis of potentialities of a family, particularly if a "service only" case. It was felt important that the agency be able to adjust function and policy quickly to take care of any family or situation which other agencies because of rules and regulations might not be able to accept. On so-called borderline cases inter-agency conferences could be called.

By 1935 it was realized by the community at large that the relief problem following the 1929 crash was no longer an emergency but a permanent problem. The agency was still carrying a great relief burden but was building up new responsibilities. The agency began to put emphasis on improving equipment to meet new demands and to get away from the psychology of an emergency. There was a need to integrate the past and the present with the future interpretation. There was an emphasis on personnel. The Family Service Organization was continuing to receive some public subsidy and although the administration of public funds was regarded as a transitional stage in the development of gov- 
ernmental responsibility, final transfer of responsibility was not made until April 1938, when the Family Service Organization no Ionger received tax funds. Use of money from the city tended to confuse relative functions of the public and private agency. With the final transfer of the major relief responsibility to the Aunicipal Bureau of Social Service, the agency faced a period of redefinition of function and the need to reinterpret services. As Mr. Linton B. Swift said in his Family Welfare Association of America pamphlet on "New Alignments between Public and Private Agencies", the agency's

community status must be judged in the
future by the kind and quality of its
job and by its community leadership,
rather than primarily by the quanti-
tative standards so familiar in the
past -- size of staff, of case load,
and of budget.
Social case work would deal more and
more with situations in which the indi-
vidual is blocked, not by external con-
ditions beyond his control, but by the
need for developing his own internal
capacity for self expression and social
self maintenance.

With the change in function and the reduction in relief budget $(\$ 106,892.79$ in 1937 and $\$ 56,565.25$ in 1938) the agency faced the need to limit, to select, to experiment, and to stress quality rather than quantity.

\footnotetext{
I.

Linton B. Swift, "New Alignments between Public and Private Agencies in a Community Family Welfare and Relief Program", Family WeIfare Association of America, 1934, 2. $\mathrm{p} .60$.
} 
A study ${ }^{l}$ made of monthly averages of number of cases, number on relief, monthly intake, and number of cases of the Family Service Organization for the years 1929 to 1936 indicates that the number of cases accepted at intake, major and minor care cases, was fairly constant until 1932 and 1933 as shown in the following table:

\section{Table XX}

Major and Minor Care Intake 1929 - 1936 including Monthly Averages and Number of Cases for Major Care Intake

\begin{tabular}{|c|c|c|c|}
\hline Year & $\begin{array}{c}\text { Average } \\
\text { Monthiy } \\
\text { Intake }\end{array}$ & $\begin{array}{c}\text { Number } \\
\text { Qf Cases }\end{array}$ & $\begin{array}{c}\text { Minor } \\
\text { Service }\end{array}$ \\
\cline { 2 - 4 } & 207.5 & 843 & 116 \\
\hline 1930 & 227 & 983 & 250 \\
\hline 1931 & 247 & 1754 & 505 \\
\hline 1932 & 324 & 2157 & 565 \\
\hline 1933 & 137 & 1249 & 788 \\
\hline 1934 & 98 & 1171 & 534 \\
\hline 1935 & 70 & 845 & 313 \\
\hline 1936 & 49 & 582 & 328 \\
\hline
\end{tabular}

The less rapid decline in 1934 indicates the state of transition when families and individuals seeking advice and referral came as they were in the habit of doing to

I.

"Graphical and Tabular Presentation and Interpretation of Some Phases of the Work of the Family Service Organization of Louisville, Kentucky, during the Years 1929 - 1936 based on Monthly Averages from the Yearly Reports of That Organization", 1937. (See Bibliography.) 
the Famly Service Organization. The Hunicipal Bureau of Social Service was just beginning its unemployment functions in 1933 and continued steering was needed because of confusion in definition of function. The sharp rise from 843 major case intake in 1929 to the 2157 peak in 1932 is noted. In 1932 the Family service Organization was administering federal unemployment relief and was given a large increase in public funds for unemployment relief. In 1933 this was administered by the Municipal Relief Bureau. From this point there was a rapid decline in cases known to the Family Service Organization and in monthly intake. In 1935 the city assumed responsibility for all pending Hothers' Aid cases. In 1935 and 1936 the city assumed responsibility for chronic dependents and the totally incapacitated.

The following table (next page) gives a picture of major care intake of white and negro cases from 1934 through 1938, showing the gradual reduction of intake as indicated in the above study. In 1937 and 1938 there seems to be a 1 eveling with a definite increase in intake in November and December 1938. This may be explained in terms of a temporary modification in intake policy. As it had been difficult to estimate monthly relief needs in view of the changed function since the transfer of the major relief responsibility to the Municipal Bureau of Social Service in April, 1938, and as intake had been unusually low during the year, in November and December 1938 a number of cases were accepted where there was only a temporary relief need, where a def- 
Table XXI

Major Care Intake, White and Negro,

in the Family Service Organization $1934-1938$

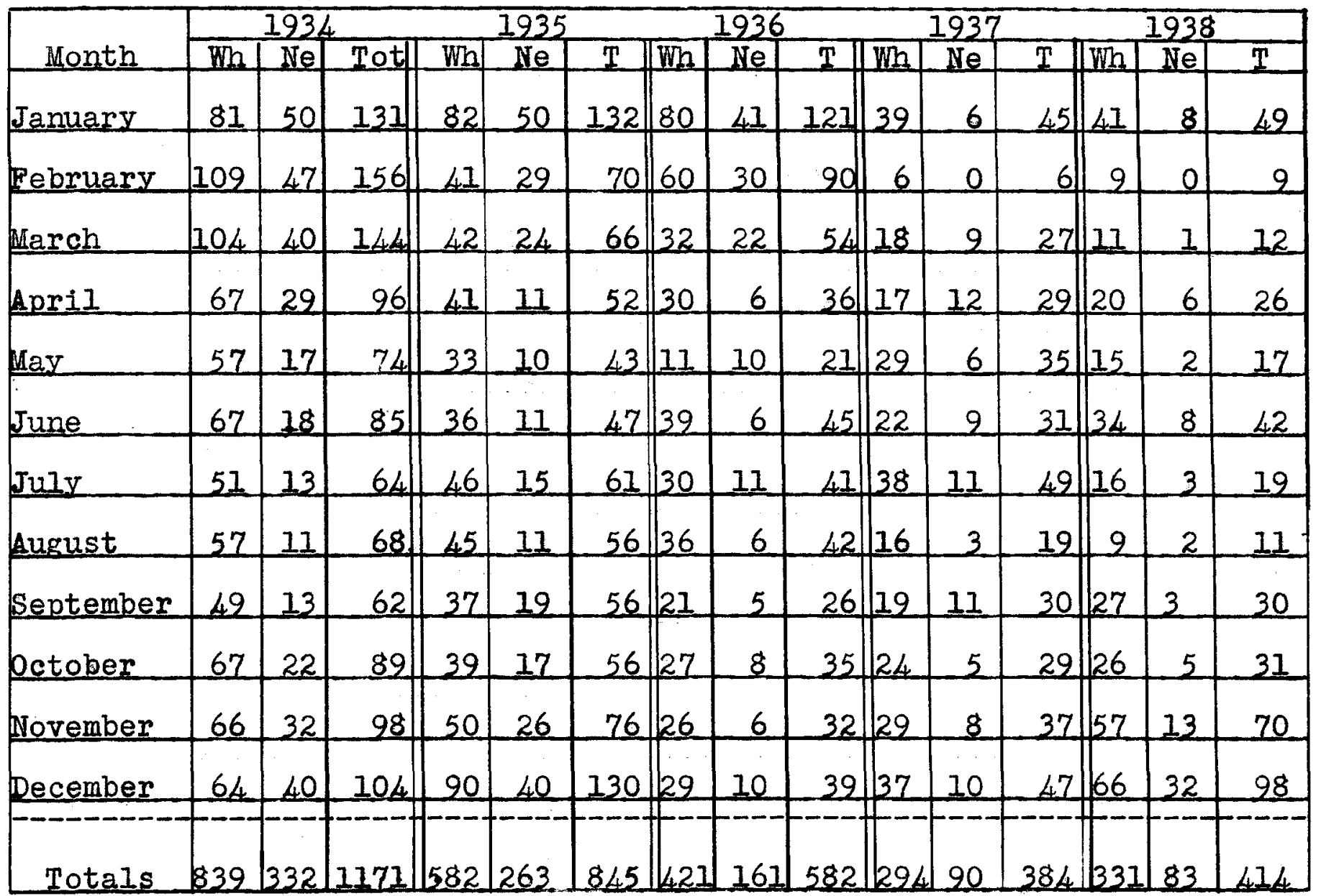

Key: White (Wh); Negro (Ne); Total (Tot or T) 
inite time limit could be set, and where there was not necessarily some other complicating problem.

Case material of the period from 1930 to 1938 was selected and grouped in three periods: 1930 to 1935, 193637, and 1938, as these years mark definite periods of increasing awareness of the intake process. In analyzing this material through the use of statistical tables and interpretation of these findings, emphasis is placed on the developmental picture which is to serve as background and lead up to the more specific analyzing of the case work job at the intake desk in 1939 and 1940.

Table XXII (see following page) gives a picture of the 111 application interviews 1930 -- 1938, according to color, religion, residence, and number of children in the family of the applicant. The significance lies in the number of protestant applications, the fact that the applicants were almost all residents of the city, and that the families applying were small in size with the largest group having one or two children.

In the accompanying table it will be noted that about twice as many applications were made by the woman in the family as by the man (see table XXII, p. 87).

It was noted that in the years from 1930 to 1935 the client's request centered in the statement of financial need. There was evidence of the influence of business conditions especially in relation to unemployment and job lay offs. Although the client was not encouraged to discuss his 
Table XXII

Identifying Information on Cases Read for the Years 1930 - 1938

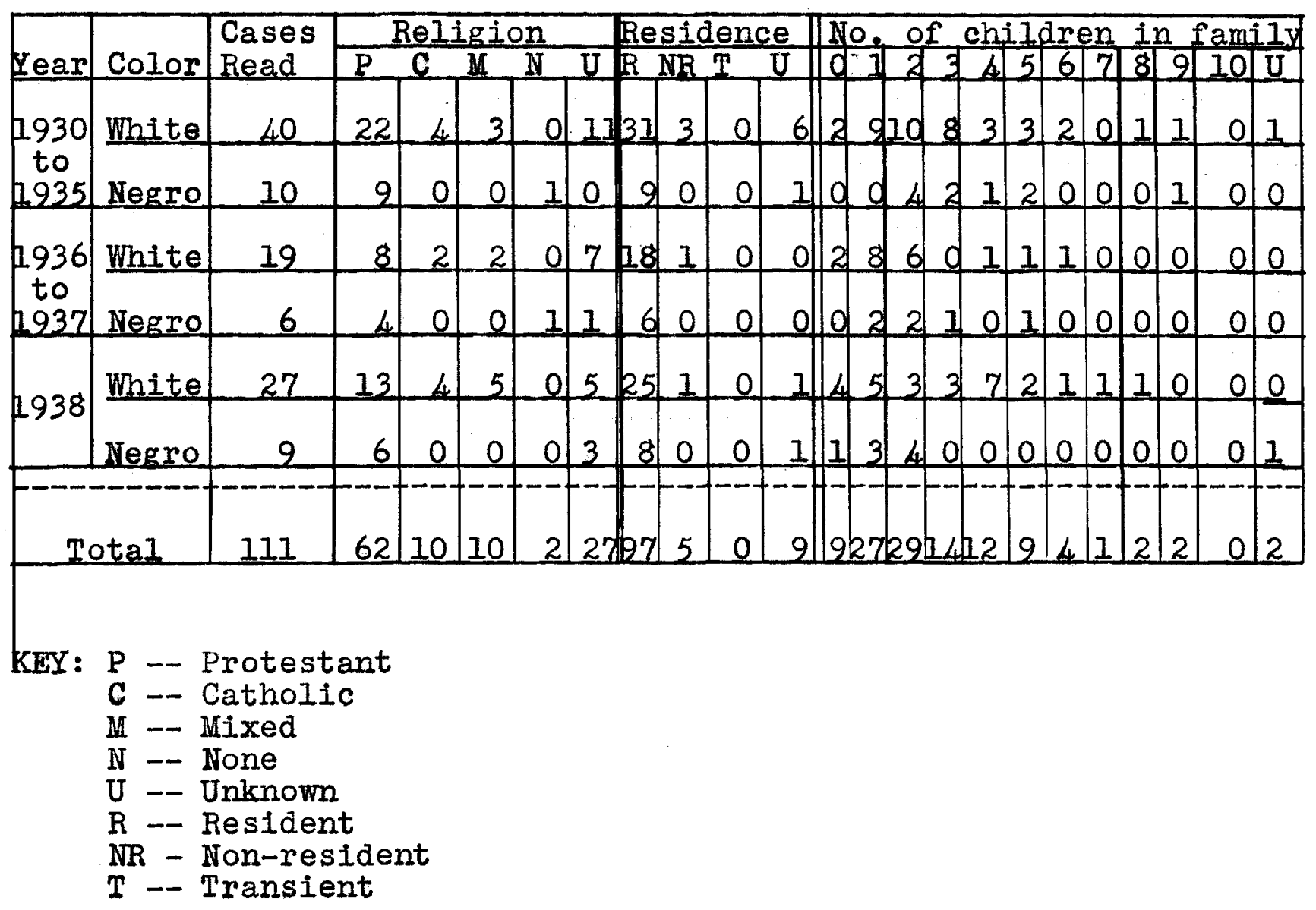


situation in detail, the intake person was often aware of some other problem in the situation such as a health problem, the extreme youth of a couple, domestic discord, nonsupport, etc.

Table XXIII

Source of Intake $1930-1938$

A. Personal Application

\begin{tabular}{|r|r|r|r|r|r|r|r|}
\hline Year & Color & Man & Woman & $\begin{array}{c}\text { Man \&oman } \\
\text { Womila }\end{array}$ & $\begin{array}{c}\text { Un- } \\
\text { Knomn }\end{array}$ & Total \\
\hline $\begin{array}{c}1930 \\
\text { to } \\
1935\end{array}$ & White & 10 & 16 & 0 & 2 & 0 & 28 \\
\hline $\begin{array}{c}1936 \\
\text { to } \\
1937\end{array}$ & White & 2 & 7 & 0 & 0 & 0 & 9 \\
\hline 1938 & Wegro & 0 & 3 & 0 & 0 & 0 & 3 \\
\hline & White & 4 & 11 & 2 & 0 & 0 & 17 \\
\hline Negro & 1 & 2 & 0 & 1 & 0 & 4 \\
\hline
\end{tabular}

The intake interviews during 1936 and 1937 seem to have a more personal quality in that there is more discussion of the problem the client brings. The situations appear to be more complicated as there is more discussion but little tying together of facts or setting of goals of treatment, or time Iimits.

In 1938 there seems to have been a step toward definitely more lengthily recorded intake interviews. There was a tendency for the worker to attempt to explore all areas of the clients' performance, not just the area in which he wanted help. There was complete factual information particularly in 
relation to the employment and financial situation, ability of relatives to assist, etc. There was usually a full statement of the client's request. Some of the requests made were: help in securing a WPA job so the client can be independent of relatives; help in reestablishing a home broken because of financlal need; help in budgeting and managing income; help in problems of domestic trouble, et. By 1938 emphasis was placed on the desirability of the office intake interview, the necessity of privacy in interviewing.

Only a small number of cases during this period were accepted upon referral by individuals.

Considering referrals from other agencies in 1930 to 1938 we find a comparatively small number of agencies referring cases. As will be seen in table XXIV (page 89), for the entire period the largest number of cases was referred by the Municipal Bureau of Social Service. In the three cases referred by this agency in 1930 - 1935, the referral was made on the basis of the man being unable to continue on work relief either because of illness, temporary incapacitation, or inability to adjust on the work relief program. Referrals made in 1936 and 1937 were on the basis of need for relief and clarification of problems because of the client's emotional disturbance.

Other agencies referring cases in the years 1930 1935 referred cases primarily because of relief needs. Agencies referring cases in 1936-37, particularly the Louisville City Hospital, referred cases for "study of the sit- 
uation and reliefn.

\section{Table XXIV}

Source of Intake - Sample of Cases 1930 - 1938

B. Referrals by Individuals

\begin{tabular}{|c|c|c|c|c|c|c|c|}
\hline Individual & 193 & -35 & 1936 & -37 & 1 & 938 & \\
\hline Referring Case & White & Negro & White & Negro & White & Negro & Total \\
\hline bther FSO client & 0 & 0 & 1 & 0 & 0 & 0 & 1 \\
\hline Ginister & 0 & 0 & 1 & 0 & 0 & 0 & 1 \\
\hline Priest & 1 & 0 & 0 & 0 & 0 & 0 & 1 \\
\hline Relative & 0 & 0 & 1 & 0 & 1 & 0 & 2 \\
\hline Community person & 1 & 0 & 1 & 0 & 1 & 1 & 4 \\
\hline Employer & 0 & 0 & 0 & 0 & 1 & 0 & 1 \\
\hline City Health Nurse & 0 & 0 & 0 & 0 & 1 & 0 & 1 \\
\hline Mayor's Office & 1 & 0 & 0 & 0 & 0 & 0 & 1 \\
\hline $\begin{array}{l}\text { Merchant } \\
\text { Policeman }\end{array}$ & 1 & 0 & 0 & 0 & 0 & 0 & \\
\hline Neighbor & 1 & 0 & 0 & 0 & 0 & 1 & 2 \\
\hline Total & 5 & 0 & 4 & 0 & 4 & 2 & 15 \\
\hline
\end{tabular}

By 1938 other agency referrals were more specific in nature although there was the tendency for the referrals to be prompted primarily by financial need. This was not true of the Legal Aid Society referrals. (During 1938 by agreement with the Legal Aid Society a Family Service Organization worker had office hours at the Legal Aid Society office and interviewed clients referred by the lawyers.) Whe Louisville City Hospital referrals centered in health problems complicated by financial need. 
Table XXV

Source of Intake - Sample of Cases 1930 - 1938

C. Referrals by Other Agencies

\begin{tabular}{|c|c|c|c|c|c|c|c|}
\hline Agency & 1930 & -35 & 1936 & -37 & & 238 & \\
\hline Referring Case & White & Negro & White & Megro & White & Negro & Tota] \\
\hline Forwarding Center & 1 & 0 & 0 & 0 & 0 & 0 & 1 \\
\hline Out of Town & 1 & 0 & 1 & 0 & 0 & 0 & 2 \\
\hline $\begin{array}{c}\text { Community Chest } \\
\text { Complaint }\end{array}$ & 1 & 0 & 0 & 0 & 0 & 0 & 1 \\
\hline $\begin{array}{l}\text { Municipal Bureau } \\
\text { of Social Service }\end{array}$ & 3 & 0 & 3 & 1 & 1 & 0 & 8 \\
\hline Mothers' Aid & 1 & 0 & 0 & 0 & 0 & 0 & 1 \\
\hline $\begin{array}{c}\text { Louisville } \\
\text { City Hospital }\end{array}$ & 0 & 0 & 2 & 1 & 2 & 1 & 6 \\
\hline Children's Agency & 0 & 0 & 0 & 1 & 0 & 0 & 1 \\
\hline Legal Aid Society & 0 & 0 & 0 & 0 & 2 & 0 & 2 \\
\hline $\begin{array}{l}\text { St. Vincent } \\
\text { de Paul }\end{array}$ & 0 & 0 & 0 & 0 & 1 & 0 & 1 \\
\hline $\begin{array}{l}\text { Travellers } \\
\text { Aid Society }\end{array}$ & 0 & 0 & 0 & 0 & 0 & 1 & 1 \\
\hline $\begin{array}{c}\text { 0ld Age } \\
\text { Assistance }\end{array}$ & 0 & 0 & 0 & 0 & 0 & 1 & 1 \\
\hline Total & 7 & 0 & 6 & 3 & 6 & 3 & 25 \\
\hline
\end{tabular}

Table XXVI

Status of Application of 111 Cases 1930 - 1938

\begin{tabular}{|c|c|c|c|c|c|}
\hline Year & Color & New & Old & Rec & Unk \\
\hline $\begin{array}{c}1930 \\
\text { to } \\
1935\end{array}$ & White & 27 & 12 & 1 & 0 \\
\hline $\begin{array}{c}1936 \\
\text { to } \\
1937\end{array}$ & White & 15 & 3 & 1 & 0 \\
\hline Negro & 3 & 3 & 0 & 0 \\
\hline 1938 & White & 22 & 2 & 3 & 0 \\
\hline & Negro & 8 & 1 & 0 & 0 \\
\hline \multicolumn{2}{|c|}{ Total } & 84 & 21 & 6 & 0 \\
\hline
\end{tabular}

Key :

Rec - Recurrent

Unk - Unknown 
Table XXVI indicates status of the 111 cases read according to new, old, or recurrent classifications. The majority of cases accepted were new to the agency.

Table XXVII

Family Status of 111 Major Care Acceptances $1930-1938$

\begin{tabular}{|c|c|c|c|c|c|c|c|}
\hline Family & 1930 & -35 & 1936 & -37 & & 938 & \\
\hline Status & White & Negro & White & Hegro & White & Negro & Total \\
\hline Married & & & & & & & \\
\hline Couple & 25 & 5 & 9 & 2 & 17 & 4 & 62 \\
\hline $\begin{array}{l}\text { Common Law } \\
\text { Counie }\end{array}$ & 0 & 0 & 0 & 0 & 0 & 0 & 0 \\
\hline $\begin{array}{l}\text { Jnmarried } \\
\text { Couple }\end{array}$ & 0 & 0 & 0 & 0 & 0 & 0 & 0 \\
\hline $\begin{array}{l}\text { Unmarried } \\
\text { Wother }\end{array}$ & 0 & 0 & 0 & 0 & 0 & 1 & 1 \\
\hline Widow & 6 & 0 & 0 & 0 & 1 & 1 & 8 \\
\hline Widower & 0 & 1 & 2 & 0 & 1 & 1 & 5 \\
\hline Deserted & 1 & 3 & 3 & 1 & 3 & 0 & 11 \\
\hline Diyorced & 1 & 0 & 0 & 1 & 0 & 0 & 2 \\
\hline Separated & 3 & 1 & 4 & 2 & 5 & 2 & 17 \\
\hline Single Man & 0 & 0 & 1 & 0 & 0 & 0 & 1 \\
\hline $\begin{array}{l}\text { Single } \\
\text { Woman }\end{array}$ & $I$ & 0 & 0 & 0 & 0 & 0 & 1 \\
\hline Unknown & 3 & 0 & 0 & 0 & 0 & 0 & 3 \\
\hline rotal & 40 & 10 & 19 & 6 & 27 & 9 & 111 \\
\hline
\end{tabular}

Table XXVII indicates the family status of the samples read. The applications by married couples predominate. The following series of tables (XXVIII a, b, c, $d$, and e) give a picture of the financial status of the group 
of cases read ( 1930 - 1938), the income of the family if economically independent, and why the family needing relief requested either supplementary help or maintenance relief.

Table XXVIII

A. Financial Status

\begin{tabular}{|c|c|c|c|c|c|c|c|}
\hline Financial & 1930 & -35 & 1936 & -37 & & 238 & \\
\hline Status & White & Negro & White & Negro & White & Negro & Total \\
\hline $\begin{array}{l}\text { Iconomically } \\
\text { Independent }\end{array}$ & 0 & 0 & 2 & 1 & 10 & 3 & 16 \\
\hline $\begin{array}{l}\text { Supplementary } \\
\text { Relief }\end{array}$ & 7 & 0 & 2 & 0 & 8 & 0 & 17 \\
\hline $\begin{array}{l}\text { Iaintenance } \\
\text { Relief }\end{array}$ & 30 & 10 & 14 & 5 & 9 & 4 & 72 \\
\hline Unknown & 3 & 0 & 1 & 0 & 0 & 2 & 6 \\
\hline Total & 40 & 10 & 19 & 6 & 27 & 9 & 111 \\
\hline
\end{tabular}

Table XXVIII

B. Income of Economically Independent

\begin{tabular}{|c|c|c|c|c|c|c|c|}
\hline \multirow{2}{*}{$\begin{array}{l}\text { Monthly } \\
\text { Income }\end{array}$} & \multirow{2}{*}{\multicolumn{2}{|c|}{\begin{tabular}{|l|l|}
$1930-35$ \\
White & Negro \\
\end{tabular}}} & \multicolumn{2}{|c|}{$1936-37$} & \multicolumn{2}{|c|}{1938} & \multirow[b]{2}{*}{ Tota1 } \\
\hline & & & White & Negro & White & Negro & \\
\hline 15.00 & $=$ & $=$ & - & - & 0 & 1 & 1 \\
\hline 65.00 & $=$ & - & - & $=$ & 1 & 1 & 2 \\
\hline 82.50 & $=$ & - & $=$ & $=$ & 1 & 0 & 1 \\
\hline 120.00 & $=$ & $=$ & - & $=$ & 1 & 0 & 1 \\
\hline 144.00 & - & - & - & $=$ & 1 & 0 & 1 \\
\hline WPA* & $=$ & $=$ & $=$ & $=$ & 2 & 0 & 2 \\
\hline Unknown & $=$ & $=$ & 2 & 1 & 4 & 1 & 8 \\
\hline Total & & & 2 & 1 & 10 & 3 & 16 \\
\hline
\end{tabular}

* WPA - Works Progress Administration 
Table XXVIII

C. Income of Families

Needing Supplementary Relief

\begin{tabular}{|c|c|c|c|c|c|c|c|}
\hline Weekly & 1930 & -35 & 1936 & -37 & & 938 & \\
\hline Income & White & Negro & White & Degro & White & Negro & Total \\
\hline$\$ 5.00$ & 0 & 0 & 0 & 0 & 1 & 0 & 1 \\
\hline 6.00 & 0 & 0 & 1 & 0 & 1 & 0 & 2 \\
\hline 12.00 & 0 & 0 & 1 & 0 & 0 & 0 & 1 \\
\hline WPA & 0 & 0 & 0 & 0 & 2 & 0 & 2 \\
\hline Jnknown & 7 & 0 & 0 & 0 & 4 & 0 & 11 \\
\hline Total & 7 & 0 & 2 & 0 & 8 & 0 & 17 \\
\hline
\end{tabular}

Table XXVIII

D. Reasons for Heed

of Supplementary Financial Help

\begin{tabular}{|c|c|c|c|c|c|c|c|}
\hline Cause of need & 1930 & -35 & 1936 & -37 & & 938 & \\
\hline for Suppl. Rellef & White & Negro & White & Negro & White & Negro & Total \\
\hline Inadequate Income & 5 & 0 & $I$ & 0 & 4 & 0 & 10 \\
\hline $\begin{array}{l}\text { Temporary } \\
\text { Incapacitation }\end{array}$ & 1 & 0 & 0 & 0 & & & 1 \\
\hline $\begin{array}{l}\text { Relatives, Unable to } \\
\text { Assume Fuli Burden }\end{array}$ & 1 & 0 & 1 & 0 & 2 & 0 & 4 \\
\hline $\begin{array}{l}\text { Help Establish } \\
\text { Young Couple Apart } \\
\text { From Relatives }\end{array}$ & 0 & 0 & 0 & 0 & 1 & 0 & 1 \\
\hline Under Employment & 0 & 0 & 0 & 0 & 1 & 0 & 1 \\
\hline Total & 7 & 0 & 2 & 0 & 8 & 0 & 17 \\
\hline
\end{tabular}


Table XXVIII

E. Reasons for Need
of Maintenance Relief

\begin{tabular}{|c|c|c|c|c|c|c|c|}
\hline Cause of Need for & 1930 & -35 & 1936 & -37 & & 938 & \\
\hline Maintenance Relief & White & Negro & White & Negro & White & Negro & Total \\
\hline Unemployment & 2 & 3 & 2 & 0 & 3 & 2 & 19 \\
\hline Illness & 2 & 1 & 1 & 0 & 4 & 2 & 17 \\
\hline Desertion & 1 & 3 & 2 & 2 & 1 & 0 & 9 \\
\hline Non-support & 3 & 0 & 0 & 1 & 0 & 0 & 4 \\
\hline $\begin{array}{l}\text { Iong Time } \\
\text { Incapacitation }\end{array}$ & 6 & 2 & 5 & 1 & 0 & 0 & 14 \\
\hline Man in Prison & 1 & 0 & 1 & 0 & 0 & 0 & 2 \\
\hline $\begin{array}{l}\text { Man out of Town } \\
\text { Seeking Work }\end{array}$ & 0 & 0 & 2 & 0 & 0 & 0 & 2 \\
\hline $\begin{array}{l}\text { Temporary } \\
\text { Incapacitation }\end{array}$ & 0 & 0 & 1 & 1 & 오 & 0 & 2 \\
\hline $\begin{array}{l}\text { Help Until Get } \\
\text { First Pay } \\
\text { (Job Waiting) }\end{array}$ & 0 & 0 & 0 & e & 1 & 0 & 1 \\
\hline Jnknown & 1 & 1 & 0 & 0 & 0 & 0 & 2 \\
\hline To & 30 & 10 & 14 & 5 & 9 & & \\
\hline
\end{tabular}

The number of economically independent families applying increased in 1938. There were no applications by the economically independent in the sample of cases read for 1930 to 1935.

Proportionately the number of applicants seeking supplementary relief increased and the number needing maintenance relief decreased from 1930 to 1938. For the whole perlod the largest group applying requested maintenance relief but almost half the group applied in 1930 to 1935. One can 
assume from these statistics that the agency was stressing a service program and more from the economically independent group were coming to the agency by 1938, with incomes ranging from $\$ 15$ a month to $\$ 144$ a month.

The greatest number needing supplementary assistance sought help because of inadequate incomes. One notes that in 1938 clients were asking supplementary help on a service basis in terms of being able to establish their own home apart from relatives, etc. Unemployment, illness, incapacitation, and desertion were the most notable causes of need for maintenance relief for the total period. Change of agency function is evident in the statistics cited. By 1938 there were no acceptances for maintenance rellef of cases involving long time incapacitation. Similarly the acceptances for maintenance care of desertion cases decreased. A significant point of difference in the theory of acceptances for 1930 as compared with 1938 was that in 1930 cases were accepted categorically and because there was no other agency to meet the need. In 1938 a case was not accepted on the basis of category but in relation to the need and desire of the client for casework service.

Table XXIX (see next page) indicates the growing importance attached to the office intake interview in comparison to earlier periods when many cases were accepted for investigation and a visit. The wider range of people taking intake is noted. The fact that the number of "not indicated" classifications decreases noticeably from 1930 to 1938 is an 
indication of more careful recording and a clearer picture of the worker's part in the interview.

\section{Table XXIX}

Person Who Saw the Client at the Point of Intake $1930-1938$

\begin{tabular}{|c|c|c|c|c|}
\hline $\begin{array}{c}\text { Who Saw the Client at } \\
\text { Intake }\end{array}$ & $\begin{array}{r}1930- \\
35 \\
\end{array}$ & $\begin{array}{c}1936 \\
37 \\
\end{array}$ & 1938 & Total \\
\hline Intake Secretary & 14 & 8 & 8 & 30 \\
\hline $\begin{array}{l}\text { Caseworker Who } \\
\text { Continues to Carry Case }\end{array}$ & 0 & 0 & 5 & 5 \\
\hline $\begin{array}{l}\text { Caseworker Who Does Not } \\
\text { Continue to Carry Case }\end{array}$ & 1 & 2 & 3 & 6 \\
\hline $\begin{array}{l}\text { Caseworker in Port- } \\
\text { land District office }\end{array}$ & 4 & 3 & 7 & 14 \\
\hline $\begin{array}{l}\text { Caseworker in Parkland } \\
\text { office }\end{array}$ & 0 & 0 & 1 & 1 \\
\hline $\begin{array}{l}\text { So worker at } \\
\text { Legal Aid Society }\end{array}$ & 0 & 0 & 2 & 2 \\
\hline Negro Worker & 0 & 1 & 2 & 3 \\
\hline District Supervisor & 0 & 1 & 0 & 1 \\
\hline $\begin{array}{l}\text { Caseworker } \\
\text { in Client's Home }\end{array}$ & 12 & 8 & 6 & 26 \\
\hline Not Indicated & 12 & 2 & 2 & 23 \\
\hline Total & 50 & 25 & 36 & 111 \\
\hline
\end{tabular}

Table XXX (see next page) indicates that the use of the Social Service Exchange was fairly consistent during the period from 1930 through 1938. By 1938 the intake interviewer was making more consistent use of other agency clearings althougin there was still little evidence of extensive use of a previous Family Service organization record in helping to evaluate an acceptance. The statistics below show a growth in the use of the appointment system by 1938 
although there was still a high percentage of applicants not seen by appointment.

$$
\begin{gathered}
\text { Table XXX } \\
\text { Mechanics of the Intake Interview } \\
1930-1938
\end{gathered}
$$

\begin{tabular}{|c|c|c|c|c|c|c|c|c|c|c|}
\hline & 1193 & 5 & Not & 19 & & 193 & $6-$ & Not & 19 & \\
\hline Wechanics Involved & Yes & No & Ind & NPIR & Vis & Yes & Ho & Ind & NPIR & Vis \\
\hline Social Sepvice & & & & & & & & & & \\
\hline Exchange Clearing & 25 & 0 & 25 & $=$ & $=$ & 18 & 0 & 7 & $=$ & \\
\hline $\begin{array}{l}\text { Intake Worker } \\
\text { Contact Other } \\
\text { Agencies Registered }\end{array}$ & 9 & 2 & 39 & - & - & 9 & 1 & 13 & 2 & \\
\hline $\begin{array}{l}\text { Intake Worker Read } \\
\text { Previous FSO Record }\end{array}$ & 1 & 0 & 15 & 34 & = & 1 & 1 & 9 & 14 & \\
\hline $\begin{array}{l}\text { Client Sean } \\
\text { by Appointment }\end{array}$ & 1 & 19 & 18 & $=$ & 12 & & 114 & 2 & & \\
\hline & & & 19 & & & \multirow{6}{*}{\multicolumn{5}{|c|}{$\begin{array}{l}\text { Key : } \\
\text { Not Ind - Not } \\
\text { NPIR - No previous } \\
\text { inquiry registered } \\
\text { Vis - Client seen } \\
\text { in home }\end{array}$}} \\
\hline Mechanics Involved & Ye & No & & NEIR & Vis & & & & & \\
\hline $\begin{array}{l}\text { Social Service } \\
\text { Exchange Clearing }\end{array}$ & 31 & 0 & 5 & $=$ & & & & & & \\
\hline $\begin{array}{l}\text { Intake Worker } \\
\text { Contact Other } \\
\text { Agencies Reg Istered }\end{array}$ & 18 & I & 14 & 3 & - & & & & & \\
\hline $\begin{array}{l}\text { Intake Worker Read } \\
\text { Previous FSO Record }\end{array}$ & 2 & 0 & 11 & 23 & $=$ & & & & & \\
\hline $\begin{array}{l}\text { Client Seen } \\
\text { by Appointment }\end{array}$ & & 10 & 6 & & 6 & & & & & \\
\hline
\end{tabular}

From case material and method of recording one realizes that in the early thirties the application work was a time consuming, driving kind of work with emphasis on quantity of work done. Information recorded was largely factual. One had little picture of the activity of the client or the worker. The application worker sent the "blue slip" (application form) to the district where the case would be assigned to a worker. The "blue slip" contained primarily factual in- 
formation and a statement of need. There was little discussion as to what the agency had to offer or how this might fit into the client's need. Relief was the primary help offerred and exploration of further needs was left to the worker who was to carry the case. Plans for the next contact usually stated or implied that a visit had been promised.

By 1936 and 1937 there was some change in the application interview. The worker was giving some more interpretation of the agency and services that were available. Some of this new concern about techniques was no doubt at the impetus of a staff committee on intake. Meetings were held regularly to discuss application material. The statement would appear in interviews that the case was being accepted for further exploration or study. One case in particular was accepted $n_{\text {to }}$ help the client to work through her problems". It was noted that study might indicate need for referral to the Mental Hygiene Clinic. Certain limitations for treatment were noted. This seems to be an example of the new emphasis -- the analyzing and beginning diagnostic process in the application interview. Other interviews frequently contained statements such as "the client seems to be in conflict", "the problems seem to be deeper than those of illness", "personality difficulties", "we question how treatable the woman is", etc. One is impressed during this period, however, with the client's having little activity in establishing his eligibility for help from the agency 
except in relation to financial need. There was little helping of the client to focus his problem. This seemed to be a period of awareness of problems. Casworkers, however, were groping as to techniques of defining how the function of the agency might be applied to the individual needs and how they might help the client to be mutually a part of the intake process.

In 1938, the Family Service Organization worker at intake was still "problem Conscious" and was apt to "read in" some family problem when the client was asking and wanted only financial help. Because of gaps in the public agency program and because of the recent relinquishing of the major relief function of the agency, there was confusion as to the return to a function which was primarily a service function apart from relief giving. Intake interviews in 1938 stress services offered by the agency.

Problems which the client brought included need for budgeting help, need for work so client could remain independent of relatives and of relief work, financial need complicating problems of tenancy, desertion, discipline of children, etc. Problems which the workers saw were: immaturity of the "young married couple", "in-law" trouble, indebtedness, differing cultural backgrounds of a couple causing friction in the home, "emotional problems", tense home situation, need to adjust to separation, etc. Because of the emphasis on services available, several examples which seem to be fairly typical of the 
interpretation given are cited. The worker in one case stated that in addition to the function as a relief agency we "also found it helpful to young couples to have an interested person outside the family to help work things out". In another case in which the client asked for budgeting help, the worker stated in the recorded interview that with the adequate income in the family it would seem that some help could be given in the area requested and that if accepted perhaps we might be able to reach other problems later. In a third case the worker interpreted the agency function in terms of being able to help with such problems as the client is bringing (marital discord) and offerred the service of having someone to talk to and to help her see both sides of the question.

In a fourth case the worker stated that the agency could not offer long time relief but could give emergency help until the client "draws a pay". To a WPA worker applying, the caseworker told the client that he was one of a group to whom we could not offer financial help but we could give service. A number of times the interviewer interpreted the Family Service Organization in comparison to the Municipal Bureau of Social Service, differentiating the two in terms of the Family service Organization's not being a relief agency and the fact that the Family Service Organization gave "other services". At other times instead of defining function in terms of the client's request, the worker would give a list of general problems with which 
the agency could give help and this served to be confusing to the client.

In evaluating the activity of the client and the worker in the intake process during 1938 there is indication of developing concern about intake interviewing skills. As an example an interview is cited in which the client came to the office wanting help in encouraging his wife to be a better housekeeper and manager and to be more economical. The worker sensed in the client's manner and presentation of the trouble that this was not the real problem he was trying to bring. She helped the client to express his own guilt, in his own behavior toward his wife, by picking up clues that the client gave from time to time as his real concern. The worker then analyzed the interview, sensing that perhaps she encouraged the'client to bring out too much in the application interview and it might be difficult for him to return. The worker questioned whether she was too direct and may have forced the client to verbalize what he was too confused to state clearly. This interview illustrates the growing concern about techniques in allowing the client to participate. Along with these interviews there were many factual interviews in which the process was not clear and it was difficult to discern on what basis the case was accepted, at least in relation to the client-worker understanding at the time of the intake interview. In these interviews there was a tendency to impose services on the client. There was a manipulative emphasis. It is evident that in 1938 there was 
a variety in cases accepted and an inconsistency in techniques used at the intake desk.

The agency's increasing concern over defining function and clarifying processes is indicated. Following the final transfer of the major relief responsibility, in April 1938, to the Municipal Bureau of Social Service, the agency faced this difficult task and the development of the intake processes indicate a continuing process of development and refinement of skills. It is proposed from this point to anaIyze and develop this process in terms of new emphases and contributions that might be inherent therein and to view the work of the Family Service Organization at the intake desk in 1939 - 1940 as a crystallization of a developing intake process with inherent implications for future growth and development. 
CHAPTER III

ANALYSIS OF THE INTAKE PROCESS

IN THE FAMILY SERVICE ORGANIZATION 1939 - 1940 
Chapter III

An Analysis of the Intake Proeess

in the Family Service Organization in 1939 and 1940

In tracing the gradual development of the intake process in the Family Service Organization, the years 1939 and 1940 may be characterized as years of crystallization of an intake philosophy in terms of redefintion of agency function and refinement of case work skills at the application desk. The increasing emphasis which the agency placed on the application interview in the late nineteen thirties has been noted. By 1939 the agency was regarding the intake process as an integral part of the total case work job. Professional literature of this period was stressing selective intake in positive terms of what the agency could do rather than what it could not do, and was stressing the defining of agency function in relation to the need the client brings to the agency. As Miss Beatrice Levey elucidated in an article on "The Extent of the Intake Interview", 1 the concept of the intake interview had evolved from a relatively unimportant task done by clerical workers to a place of ever increasing importance demanding services of the most skilled staff.

In the nineteen twenties caseworkers had begun to assimilate the fact that feelings about facts were impor-

1. Beatrice $z$. Levey, "The Extent of the Intake Interview", Intake in Public and Private Agencies, p. 20 
tant. Following a period of over activity on the part of the worker, workers approached the interview by saying in response to the client's request for help, such things as "how do you feel about it?", "it must be hard for you". This listening technique left the client to struggle with his own problem with little help from the caseworker in terms of focusing the problem about which he might do something. By 1939 and 1940 as the caseworker had grown in understanding of the techniques and attitudes involved in the intake process, she was increasingly cognizant of the client's attitude in terms of his insecurity and anxiety in seeking help. She was increasingly aware that to ask implies a dilemma which the client cannot solve by himself. The client would need help in discussing his problem and his need. He would need guidance in setting goals in relation to the help the agency might offer him. Caseworkers were more aware of the intricacies of the helping process. An application is used here as an illustration of the "helping process" and through discussion of the case this process will be defined in terms of the interaction between persons asking and offering help

as a technical process basic to the exercise of every social work function. The taking and giving of help are seen as two opposite but complementary currents in a single complex process on which social work must base whatever it hopes to achieve in the way of effective understanding of the client and conscious control over its 
own procedures. 1

6-10-40 The client came to the Family Service Organization with her two young children. She did not have an appointment but asked the receptionist whether she might see someone today as she was not feeling well and it was hard for her to get out. She was pregnant. She appeared to be forty or forty-five years old but as identifying information was obtained she said she was thirty-five. She knew she looked older. She did not know just when she would be confined. She had lost track of time. They had not planned for the baby. She had gone from week to week hoping things would be better and now she was completely confused as to what to do. The worker asked her how she happened to come to the Family Service Organization. She said she was a graduate nurse and had heard of the agency through her practice. As she had not mentioned her husband the worker asked about him. He had worked for nine years for a drug company until the company went into receivership. Things went from bad to worse. She gave some history of the trouble. She said her husband was haggard and worried, too. The worker had a feeling the couple might be separated but there were no facts to substantiate this. The woman was confused as to facts and was concerned about herself physically and her "mantal state". She wanted to get settled as she and the children were living in a hotel temporarily.

"We then made several suggestions as to how the present need might be met, in an effort to allay some of the anxiety. The client had expressed concern about her condition, time of confinement, etc. She had no money for a private doctor. We suggested the City Hospital clinics. She said any place where some arrangement might be made."

At this point the worker was active in calling the social worker at the Louisville City Hospital prenatal clinic for help in making arrangements for confinement, nursing care through the City Health Department Nursing Division, and postpartum care through the Visiting Nurses' Association.

"Plans were then outlined that the client would get in touch with her husband to look for furnished rooms. They had no furniture and would have to depend on furnished rooms. The client thought that with the children and her to be confined, they would have difficulty in locating rooms and would have to pay possibly six dollars a week. We discussed expenses briefiy at this point. In addition to rent, the

I.

Jessie Taft, "Introduction" to the Journal of Social Work Process, $\nabla .1$, no. 1, p. 1, Pennsylvania School of Social Work, 1937. 
client estimated that she 'gets by' on four dollars a week for food. They can make their clothing do. They owe no debts and have dropped their insurance. The client said they had only a few dollars for expenses for the next few days. We said we could offer temporary help, if it seemed after this emergency period that the family could then assume their expenses and we named a tentative six weeks to two months period. The client said she did not think they would need help that long. Her husband was trying desperately to get work. She knew that as soon as the baby came, she could get nursing assignments. She has called several friends who are nurses and they tell her she will have no trouble securing general nursing care jobs. She regains her strength quickly. Her whole appearance is different. She is confident in her ability to get work until her husband's plans work out. We cannot know what it is to have the feeling she had this morning and what a comfort it has been to talk to us.

"We further outlined plans that after finding rooms, either the client or her husband will get in touch with us. Then we can get in touch with the Works Progress Administration Housekeeping Aide office and a housekeeper can come to the home and assist with the housekeeping and care of the children. The client said she had not known of this service and tears came to her eyes as she spoke of how much better it will be not to have to place the children. (We had earlier suggested Home of the Innocents placement if other plans could not be worked out.) ...

"The immediate step was to look for rooms, then get in touch with us. Mrs. P. would go to prenatal clinic on Friday. Plans would be made in further detail as outlined above, depending on home or hospital delivery. The client again spoke of her confusion and asked that we write some of these things on a card for her. She is not herself as far as her memory is concerned. She again said how it had relieved her to talk with us. She was calmer ...

"We felt in evaluating acceptance of the case that the client had come into the office almost in panic. She felt the need for making an immediate plan. She seemed ill physically and confused mentally. She was aware of her "mental state" and had insight into the fact that she needed help because she was not her normal self. Her story was often confused, information vague, and we had many questions in relation to facts. On the other hand, we saw the client as a person asking guidance in a reality situation she could not meet. There seemed need to meet this emergency with indications that the family could pick up and go on for themselves on the basis of evident strengths." 
The worker in this intake interview noted and accepted rather than explored the client's feeling. A friendIy relationship rather than an intensive relationship with the client was initiated. This gave the client assurance of the agency's interest in helping her. The worker encouraged her to stateher problem. The worker was not a too sympathetic Iistener as this would have tended to further deter the client's ability to act. The client came to the agency in a state of panic. The worker evidently saw the client's coming to the agency as a positive impulse to help herself and to change her situation in some way. It is assumed that she had been able to resolve to some degree her wanting and not wanting to seek help.

It would have been easy for the worker to explore the client's difficulties in the past (the worker mentions almost parenthetically confusion about facts in relation to history) and to identify with the client in all the trouble she had been through. Instead the worker helps the client to identify with the new -- the way the client is seeking out of her difficulty. The client's anxiety is not allayed through just an unburdening of her troubles to a sympathetic listener but her anxiety is met by making the services of the agency a reality for her, indicating that the agency can help her in making some change in her difficult situation. The client was given some idea of the possible part the agency would take in helping her and of the part she would take in helping herself. 
After the immediate need had been met the worker was able to help the client see beyond the urgency of the immediate to what the client was planninf toward. Limitations of agency function were set in terms of a time limit which had meaning for the client and the worker. For the client it allayed fears as to what the agency would do to her and to her request for help and clarified for her, her own ability to regain independence. For the worker it set limits of the use of herself in relation to the policy of the agency. This process of helping the client to preserve her individual impulse to help herself created a sense of mutual confidence between the client and the worker. It allowed for a tentative diagnosis of the area of the difficulty and the worker's preliminary estimate of the client's and the agency's capacity to deal with this difficulty. There were simple next steps outlined for the client and the worker. The client would go to clinic, and would talk with her husband about locating rooms. Something concrete to do between this and the next interview would help to lead her out of the confusion of inactivity and would bring a sense of participation in the helping process. The worker in this case accepted the client and seemed to be in control of her own responsibility to the client, the agency and what she was there to do for both of them. The worker evidently felt secure to rely on her own judgement to understand what the client was expressing, to interpret this for herself in terms of agency function, 
and to help the client to understand what service the agency had to offer her. This was accomplished rather simply without the need to put this process into words -- "an understanding simply expressed, between the client and the worker, of what the agency can do and how it works in relation to that particular client". 1

- the application process contains the potentialities of case work as a whole. Like all other case work contacts it is initiated by the client and his need, and it evolves out of the relationship between two people -- the client and the worker. The spontaneous interplay of forces in this relationship finds form, direction and indication for action in the limitations of agency function, the client's degree of awareness and his readiness to take help, the caseworker's capacity to observe, and give help, and time. As it embodies and puts into operation all forces that determine and control casework relationships, it is fundamentally and actually dynamic.

With this defining of the "helping process", further analysis of the intake process will show how the Family service Organization makes use of this technique in practice.

1.

Harriet Guignon, "Defining Function in Specific Cases", Defining Family Case Work Services in Relation to Client 2. Applications, Family Welfare Association of America, 1938. Else Jockel, Movement Toward Treatment in the Application Interview in a Family Agency", The Journal of Social Work Process, $\nabla .1$, no. 1 , p. 40 . 


\section{Developments in Intake Set Up \\ and Policies in 1939 and 1940 in the Family Service organization}

The study of the Louisville Community Chest agencies made in the winter of 1939 offered recommendations as to change of intake set up in the Family Service Organization.

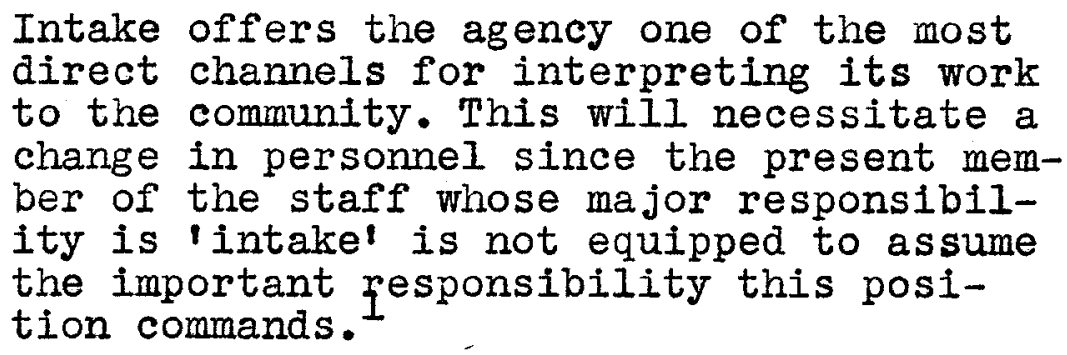

The study also emphasized the agency's need to broaden its function in practice. The Family Service Organization was to think less in terms of such problems as truancy, neglect of children, etc., and more in terms of understanding underlying causes and the services to be rendered. More emphasis was to be given to consideration of services in relation to preventing family breakdown. This would call for well integrated skills on the part of the caseworkers. The survey's findings indicated an unevenness in intake work. Factual information obtained was adequate, observation on marital and parentchild relationships was excellent, but the intake interviewer did not always make effectual use of the factual material as a tool in understanding and helping the client to

1.

Community Chest Survey Study, March 1939. 
express other needs. This process would necessitate an increasing consideration of diagnosis and early treatment plans in areas in which caseworkers in the agency were as yet less familiar.

The Family Service Organization, in view of the comparatively recent change of function, faced the difficult task of interpreting its new function to the community. "It will take some time", according to Miss Lowry, "before the community will cease to turn to (the private agency) for the old services, and the reinterpretation of the agency to the community may proceed slowly because it must combat this tradition. ${ }^{I}$ Miss Lowry also reminds us that this change in function to be made effective is not only a matter of the competence of the individual caseworker, but also the extent to which the agency setting contributes to therapeutic activities and the degree of reinforcement which the agency and community can supply. . The caseworker is one of a triumvirate consisting of the client, the community, and herself. 2

Previous to June 1, 1939, there was a full time intake secretary. Following the recommendation of the Community Chest survey there was reorganization in the intake department. A schedule was evolved whereby each caseworker was to serve two half days a week at the intake desk, from 12:30 one day to 12:30 the next day. Decision on acceptances rested with the worker taking intake and her supervisor.

\footnotetext{
1. Fern Lowry, "Problems of Therapy in Family Case Work",
} 2. Social Service Review, v. 5, no. 2, June 1936. 
Cases where agency policy might be uncertain or where further discussion was needed to clarify some aspects, could be discussed with the case supervisor or the executive secretary. Responsibility for inter-agency conferences rested with the case supervisor.

From June 1939 until January 1940 (when use of the separate district office had been discontinued) workers in the Portland district office continued to take their own applications. A worker held office hours in the Parkland library twice a week and took applications there for the Parkland area.

Early in 1939 an agency intake committee was reorganized to evaluate the mechanics of the application department and to make necessary readjustments to increase efficiency of the intake functioning. The system of having caseworkers serve part time at the intake desk seemed to be satisfactory except for the amount of time which the intake work took from the caseworker's week. At the recommendation of the intake committee, the plan of having caseworkers, supervisors, and case supervisors each serve only a half day a week was started. The aim was to schedule appointments for clients living in a certain district to be interviewed at a time when a worker from that district was at the application desk.

In December 1939 and January 1940 a part time worker was at the intake desk several days a week to relieve the regular workers and particularly supervisors for other 
responsibilities. This worker's job was primarily one of determining whether or not a client should be given an appointment to see a regular intake worker. Because of the nature of a need which a client might present, the worker occasionally accepted cases after consultation with the case supervisor. In the fall of 1940 a part time worker (a caseworker who had recently left the agency) was again at the intake desk to help relieve the pressure of the intake job because of staff turnover.

Intake procedure remained essentially the same during 1939 and 1940. As mentioned above, turnover in staff has meant that as new workers have taken intake responsibility there has been a period of adjustment necessarily interrupting consistency of performance at the point of intake.

The public relief situation in Louisville and the gaps in the relief program undoubtedly influenced workers in their decisions at the intake desk. Again the Community Chest survey pointed to the fact that Louisville had the same social problems as other cities but that these problems were intensified by the lack of adequate public relief. The Bulletin of the Council of Social Agencies of the Louisville Community Chest of April 10, 1940, indicated that direct relief was refused by the Municipal Bureau of Social Service when:

a. There is an "employable" member.

b. The wage earner is receiving unemployment compensation benefits. 
c. The client is eligible for old age assistance.

d. The employable member of the family has been certified but not assigned to a Works Progress Administration project.

e. Works Progress Administration wages are insufficient for the support of a large family.

f. The family's earnings are insufficient from part time employment.

g. The mother has been "recently deserted".

h. The wage earner is "temporarily ill".

i. The employable person has a non-acceptable work record.

j. The employable person is able to do only light work.

k. The applicant has relatives able to assist.

At a meeting of the Family division of the Council of Social Agencies, Miss Gertrude Richman, director of the Municipal Bureau of Social Service, reported that as of Hovember 1, 1940, the intake policy of the Municipal Bureau of Social Service was based on the needs of the individual family. There would be no categorical refusals. This change in intake policy of the Ifunicipal Bureau of Social Service meant that where there was a financial need only, whether it was a case of supplementing a small income or a family needing full maintenance relief, the Family would be referred to the Nunicipal Bureau of Social Service rather than to the Family Service organization.

As a basis of clarification of later discussion, the following statement of intake function of the Family Service Organization as prepared for interpretive purposes 
in Novemer 1940 by the agency as a member agency of the Councll of Social Agencies reads:

The Family Service Organization accepts resident families where case work service is needed and desired by the family on such problems as budgeting, vocational guidance, marital difficulties, and personality maladjustments -- families such as the following:

1. Young couples having their first domestic difficulties.

2. Families where emotional problems are caused or complicated by illness, physical or mental.

3. Motherless families where housekeeping service, budgeting, and supervision of older children are needed. 4. Families who are living on a marginal income and need advice in budgeting, marketing, and occasional supplementing. 5. Families where there is difficulty between the parents and the children or where adolescents need vocational guidance and interpretation because of the home situation.

The agency's limited relief budget is used for short time relief needs of families receiving service. The agency interviews and directs any client or community person who is doubtful as to the functions of the various agencies. 1

The usual intake procedure in 1939 and 1940 was for the client to give some identifying information as indicated on the application form (see Appendix XVII). After the name had been cleared with the Social Service Exchange, if the case was not registered active with another agency, the caseworker at the intake desk gave the client an appointment or if there were no appointments scheduled at that time she

\section{1.}

"The Responsibility of the Individual Agencies", October 25, 1940, Louisville Counc1l of Social Agencies. 
might see the client without an appointment. The appointment could be an immediate one if the situation were urgent. Ordinarily a client was asked to come to the office to make application. If for some reason this was not possible a home visit was made.

\section{Table XXXI}

Mechanics of the Intake Interview $1939-1940$

(Statistics based on reading of 50 cases, negro and white, in 1939 and 144 cases in 1940)

\begin{tabular}{|c|c|c|c|c|c|c|c|c|c|c|}
\hline \multirow[b]{2}{*}{ Mechanics Involved } & \multicolumn{5}{|c|}{1939} & \multicolumn{5}{|c|}{1940} \\
\hline & Yes & No & $\begin{array}{l}\text { Not } \\
\text { Ind }\end{array}$ & NPIR & Vis & Yes & No & $\begin{array}{l}\text { Not } \\
\text { Ind }\end{array}$ & NPIR & Vis \\
\hline $\begin{array}{l}\text { Social Service } \\
\text { Exchange Clearing }\end{array}$ & 27 & 0 & 23 & - & - & 99 & 1 & 20 & - & \\
\hline $\begin{array}{l}\text { Intake Worker } \\
\text { Contact Other } \\
\text { Agencies Registered }\end{array}$ & 20 & 4 & 23 & 3 & - & 54 & 20 & 35 & 11 & - \\
\hline $\begin{array}{l}\text { Intake Worker Read } \\
\text { Previous FSO Record }\end{array}$ & 12 & 0 & 9 & 29 & $=$ & 40 & 1 & 24 & 55 & \\
\hline $\begin{array}{l}\text { Client Seen } \\
\text { by Appointment }\end{array}$ & & 10 & & & & & 18 & 22 & & \\
\hline
\end{tabular}

*NPIR - no previous inquiry registered

Table XXXI showing the mechanics of the intake interview indicates extensive use of the Social Service Exchange. The intake worker in many instances did not indicate whether she had consulted with other agencies registered as having known the family. There is indication that the intake interviewers usually read the previous Family Service Organization record before interviewing the client who had previously been known to the agency. Clients were 
seen predominantly by office appointment.

\section{Table XXXII}

Person Who Saw the Client at the Point of Intake $1939-1940$

(White major care acceptances)

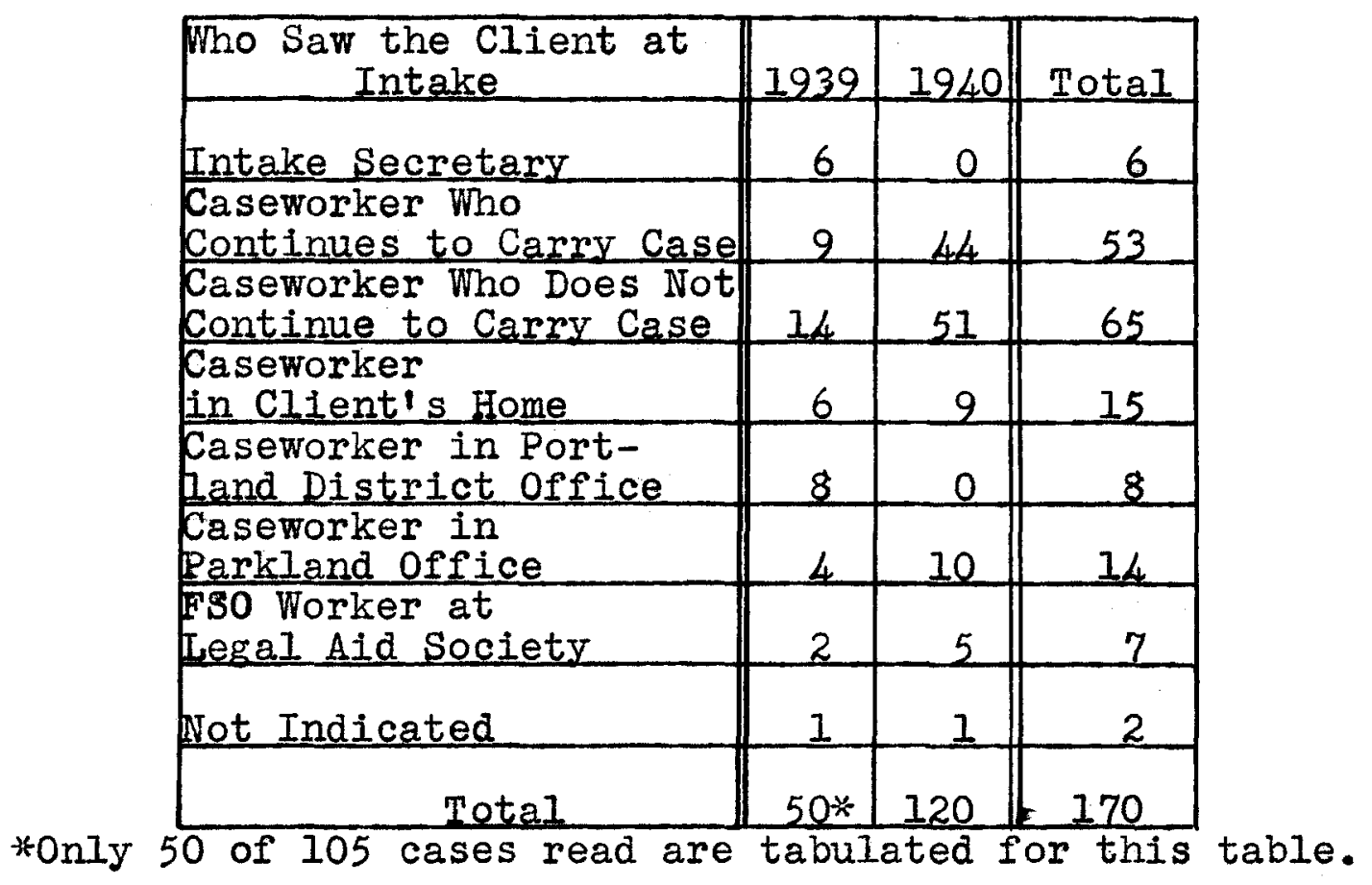

The full time intake secretary took intake until June 1939. Table XXXII indicates that in 1939 only six applications of a total of fifty studied were accepted by the intake secretary. In 1940 of the forty-four applications accepted by the intake worker who continued as the caseworker in the family, one was accepted by a supervisor who carried a small case load, thirty-five were seen by the caseworker who continued as worker in the family and the remaining eight were accepted by the former caseworker (the worker who had visited the family when the case was last known to the agency). 
Five of the eight were really continuation of former contact with the agency where the case had been closed recent1y. Did this indicate a too sudden termination of contact? In one of the eight applications the case had been closed because the family moved to the county. The closing summary indicated the client's desire for casework service and the former worker reaccepted the case, according to plan, when the family returned to the city. In another case the client telephoned the former worker and asked to talk with her as she "knew all about the situation". of the fifty-one cases accepted in 1940 by the intake worker not continuing as case worker, twenty-seven were accepted by caseworkers, eight by supervisors, six by the case supervisor, and three by workers who had known the client during a previous contact with the agency.

In all of the cases where a visit was made to the home rather than the client making application in the office, the cases had been accepted before the client was seen. For example, some cases were accepted in inter-agency conferences, others by referrals from other agencies, another was a penitentiary investigation (letter received from a penitentiary requesting a visit to the family of the prisoner to help the family in planning while the husband was in prison).

It is interesting to compare the number of acceptances indicated in table XXXII as accepted by workers in 
the various special intake situations such as in the Parkland project and the Legal Aid Society project. The Parkland worker was engaged in an active program of agency interpretation within the geographical area of the Parkland section of the city. She accepted the larger number of cases in relation to other specialized intake and continued as the worker in all cases accepted except one which was assigned to a student worker. The Family Service Organization worker seeing clients at the Legal Aid Society office continued to carry less than half the cases she accepted (in the cases read for this study). Might this be partlally explained in terms of the number of short service or minor care cases accepted by this worker at the Legal Aid Society which brings added pressure and volume of work? Also the cases accepted are from all parts of the city and are assigned to workers in the district where the client lives. Is it not possible that the service might be more effective and consistent if one worker carried not only the planning but also contimied case work with the families accepted? Six of the eight cases (negro -- see table XXXIII, next page) accepted by intake workers who did not continue as caseworkers in the family were accepted by white caseworkers, one by a negro caseworker and one by the Family Service Organization worker at the Legal Aid Society. It is an interesting observation that in analyzing who saw the applicant (white and negro) at the intake desk, approximately $50 \%$ of the applicants were seen by the worker 
Table XXXIII

Person Who Saw the Client

at the Point of Intake in 1940

(24 Negro cases read)

\begin{tabular}{|c|c|c|}
\hline Who saw the & Client at Intake & $\begin{array}{l}\text { Mumber of } \\
\text { Cases - } 1940\end{array}$ \\
\hline $\begin{array}{l}\text { Tegro Worker } \\
\text { Continues to }\end{array}$ & $\begin{array}{l}\text { Who } \\
\text { Carry Case }\end{array}$ & 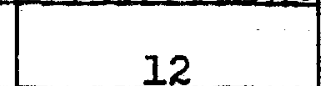 \\
\hline tor & White Intake & 勧 \\
\hline 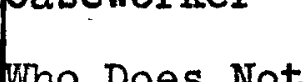 & Negro Intake & 7 \\
\hline & & \\
\hline Continue to & Superzisor & 0 \\
\hline Carry Case & Case Supervisor & 0 \\
\hline & $\begin{array}{l}\text { FSO Worker at } \\
\text { Iegal Aid society }\end{array}$ & 1 \\
\hline Caserrorker 1 & n Client's Home & 4 \\
\hline & Total & 24 \\
\hline
\end{tabular}

who continued as caseworker in the family and 50\% were seen by a worker who did not continue as caseworker. One of the purposes of the caseworkers' serving at the intake desk was to enable workers to take their own intake because of the values inherent in a continuous process of diagnosis and treatment. Authorities writing in the field of intake in case work literature do not agree that it is necessarily best for a caseworker to take her own intake. The stress seems to be placed on the techniques and skills involved in so conducting the interview that the transfer of the case from worker to worker insures a continuous treatment process beginning at the point of intake. 
It is generally agreed that the circumstances of the intake interview determine the tone of subsequent contacts. An intake interview that is too long or where too much information is obtained makes transfer to a second worker more difficult. As Dr. Leroy Maeder expressed in a Family Welfare Association of America Institute held at Minnesota University in July 1940, the intake interviewer does not want to build a strong "emotional bridge". The intake interview should be kept on a "transitory basis"; "open the door and make the client want to come in". In order to bridge the contact from one worker to another the client should be given some encouragement that his situation will be considered and that help may be forthcoming and that he may participate.

Strengths of the Family Service Organization intake procedure seem to be in the diagnostic ability of the caseworkers and in the helping of the client to express his need and in allaying anxiety. There is usually well rounded factual information. It is observed that the task of outlining possible goals of treatment and "building a bridge" from worker to worker is a skill that is to be developed by the Family Service Organization interviewer. In many interviews it was not clear in the recording as to what plans for the next contact were. (In many instances visits were promised or letters were to be sent arranging next appointments. It was observed that where a worker knew that she was to continue as caseworker in a case, some definite 
plans for the next contact were usually made along with something for the client to do such as seeing a former employer concerning a job, inquiring concerning Works Progress Administration status, suggesting that the client think over discussion of the interview, discussing the situation at home, listing budget expenses, etc.) If the intake interview is seen as a part of the total case work process, however, then the process of the intake interview and in continuing contact differs only in degree.

Intake based upon one philosophy and treatment on another must involve discrepancies and difficulties.... treatment that involves client participation calls for a participative interview. . . any preparatory process carried out by one person for another within an agency cannot lead to maximum efficiency and effectiveness unless the treatment purposes and methods of both are similar. 1

This may involve the way in which an appointment is arranged, the amount of confidence the worker gives a client, the way in which the client has a change of insight into his problems, etc.

A schism between intake and later casework processes is detrimental not only to the smooth functioning of an agency, or to inter-agency relationships, but makes for an un productive relation to the client.

As the worker uses a participative approach where the client shares the decision with the worker as to what he

1.

Herbert H. Aptekar, "The Continuity of Intake and Treat2. ment Processes", The Family, .28 , no. 1 , Harch 1937. 
thinks the agency can help him to do for himself, this can be a beginning experience in asking and receiving help, with the client identifying with the service the agency can offer him. "No one will ever really use an agency or another person for help, unless he has a substantial part in making his own decisions". 1 .

It was not always clear why a worker did or did not continue as caseworker in the application she accepted. Her not continuing with the case was sometimes determined by the pressure of an already large case load; by pressure of other agency responsibilities; or in the instances of the supervisor or case supervisor at the intake desk, by the fact that neither of these often carry cases. On the other hand there was some indication that a worker continued with the cases where she thought she had something to offer, tangibly or intangibly, or where she experienced a ready response from the client. Where the worker sensed a need for service but was vague in terms of defining the need and areas where the agency might help, was the worker more likely to think another worker might have more to offer? There is also a reality situation to be considered in the fact that appointments were often scheduled for a client living in one district to see a worker from another district. This would indicate the need for an increasing refining of the mechanics of the intake procedure.

\section{1.}

Roberta E. Townsend, "Fact and Feeling in Eligibility", The Journal of Social Work Process, $v .2$, no. 1, p. 24 . 
It is pertinent here to note that there has been a gradual improvement in the physical set up of the intake department and facilities for privacy of interviewing. In 1941 a sound proof interviewing room has been built. This is a change from the days when the applicant was seen by a clerical worker whose desk was in the waiting room where there was no privacy.

In 1940 there was a growing trend toward the use of techniques in "building a bridge" from worker to worker in the intake process affording more continuity in treatment. A negro case accepted by a white worker and transferred to a negro worker to carry the case illustrates some of the techniques discussed.

nMrs. H. was interviewed. She asked for information regarding a better job for Mary who works now for $\$ 3.00$ a week as a domestic; for financial assistance so that adequate food for Gladys, who is 21 pounds underweight, could be provided; and for guidance toward better care for the girls whose responsibility for supervision Mrs. H. seemed to feel keenly; and advice as to plans for Mrs. H's working (Mr. and Mrs. H. were rearing $\mathrm{Mr}$. H's three young sisters as the girlsi parents were dead).

Mrs. H. stated these needs most intelligently. She impressed the interviewer as a well educated person. She spoke freely regarding the sisters-in-law's need for regular physical check up including Wassermans; Gladys was receiving treatment for syphilis now.

Mirs. H. spoke fondly of 'the girls' and stated proudly that Lillian 'was skipped' in school this year. She seemed to consider seriously her responsibility and questioned whether she should go out to work and expect Mary to remain at home. She spoke of her husband almost reluctantly, saying that he was a good husband but 'so satisfied' to live from day to day and let someone else worry. She described her husband, in response to our inquiry, at which time she said, II feel funny when you ask me things like 
that'.

We terminated the interview by saying to Mrs. H. that it seemed to us that she was in need of financial help with providing food for Gladys and that we could send one quart of milk daily for the next month; it seemed that she was concerned about plans for the girls in general, the possibility of a better job for Mary and of work for herself. We felt we could help with these things. Perhaps it would help to talk further about her husband's responsibility as well as her own to 'the girls' who are his sisters. (The interviewer sensed some conflict in Mrs. H's resistance to speaking more freely regarding her husband.)

One of our caseworkers with whom we would discuss Mrs. H's application would visit the home. Mrs. H. worked on Wednesday and Saturday sometimes. Any other time would be convenient."

The caseworker in this case accepted Mrs. H. as a client who stated concretely the help she wanted from the agency. The worker met the client's request with the giving of concrete suggestions as to how the agency could meet the client's request. Question from the worker about Mr. H. brings resistance and withdrawal by Mrs. H. The worker does not press further in exploring this area but sees this withdrawal as indication of difficulties other than as expressed by $\mathrm{Hrs.H}$. and leaves this exploration to the worker who is to carry the case. The unknown is fearful to a client. Mrs. H. had given no evidence of what fears she might have brought to the interview until the worker mentioned $\mathrm{Mr}$. H. The worker seems to fear bringing out problems too soon and senses the client's fear of having the worker know too much about her in this first contact.

The activity of the worker in this interview is 
clear. The worker's agreement with the client and plans for the next worker to visit were apparently clear to the worker to whom the case was assigned. One observes, however, that the interview does not indicate that the client particlpated in the decision as to what help the agency would give to help her preserve her impulse to help herself. Did she perhaps have some fear as to what the agency would do with her request beyond meeting the immediate need? Did the ready offer by the worker to send milk for Gladys cause Mrs. H. to be fearful of the agency's taking responsibility from her in relation to supervision of the children? This might have been seen by the client as a threat to security with her husband. Would it have relieved the client's tension if there had been more clarity as to possible next steps and the client could have been working on some simple next step? This might have been handled through suggesting that Mrs. H. would want to talk over with Mr. H. the things she and the worker had talked about. Did Mrs. H. leave the interview somewhat fearful as to what the worker who would visit her might do in trying to help her? The worker who was to visit had no tangible entrance to the case. There was no continuing thread of beginning treatment process to be picked up except as the worker chose to make some of the general areas of suggested help more specific. The client would, in the next interview, still be asking clarification of how the agency might help her, rather than continuing a process of the worker and the client 
together determining goals of treatment. 
General Statistics on Intake of the Family Service Organization $1939=1940$

Table XXXIV

Major Care Intake 1939 - 1940

According to New, 0ld, or Recurrent Status Including Negro and White Applications

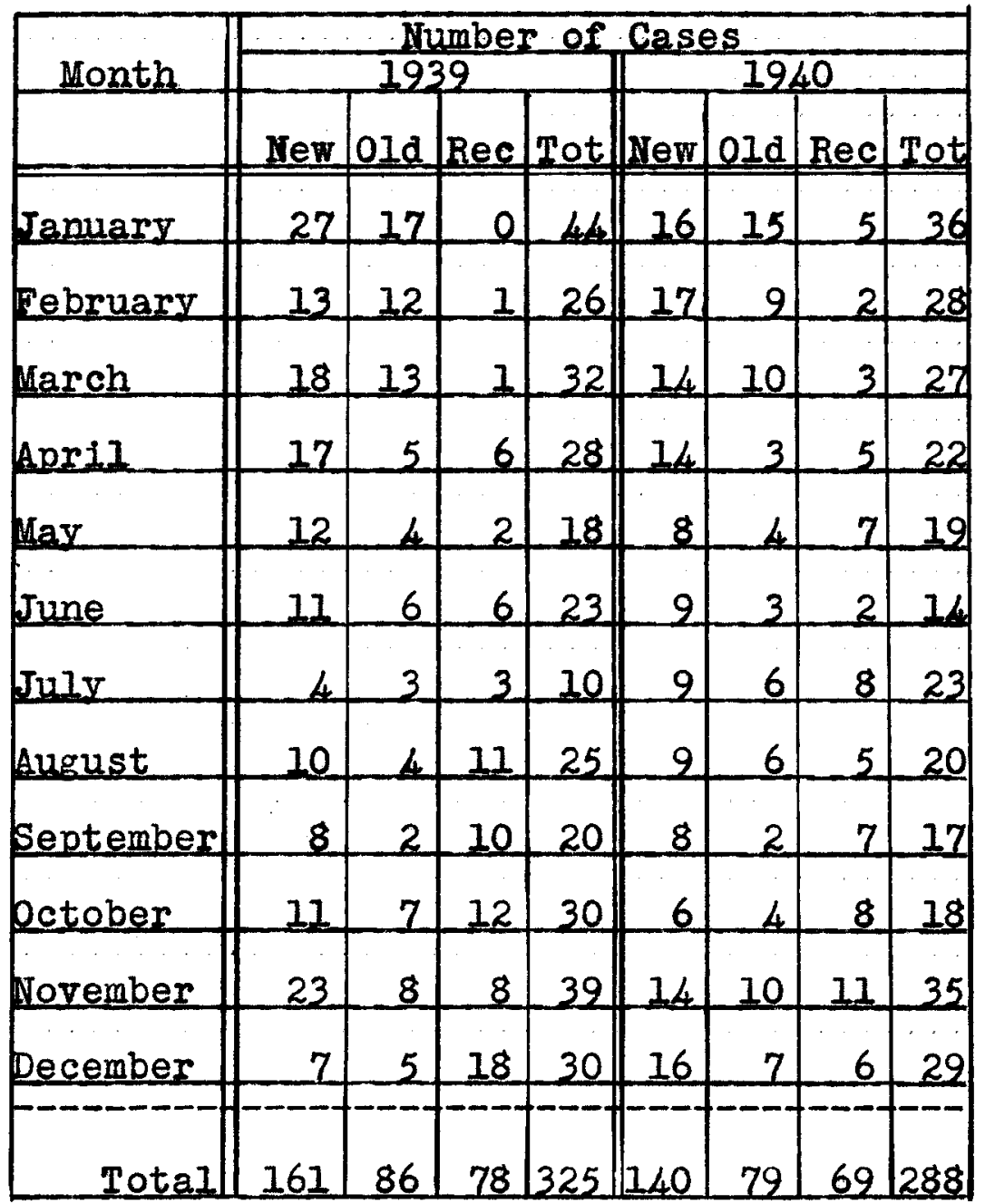

Statistics for 1940 show a declining intake for many private family welfare agencies, accentuated during the first two months of 1941. In some instances the reduction of intake has been so marked as to leave a rather attenuated program; in others it has 
merely reduced case loads to a point where better work is possible. But as rellef needs decrease, and as public agencies improve and broaden their services to 'relief' clients, private agencies may expect a continued decline in intake as long as they continue to serve approximately the fame clientele as the public agencies.

\section{Table XXXV}

Classification of Major Care Acceptances (White) for the Year 1940 According to New, 0ld, or Recurrent Status and According to the Major Problem Presented

\begin{tabular}{|c|c|c|c|c|c|c|c|c|c|c|c|}
\hline & \multirow{2}{*}{\multicolumn{4}{|c|}{$\frac{\text { Status }}{\text { OIdIRec|To }}$}} & \multicolumn{7}{|c|}{ Classification of Problem Presented } \\
\hline Month & & 210 & $\operatorname{Rec}$ & Tot & Feon & Fam & $\mathrm{Com}$ & Phys & Pers & Ment & Unk \\
\hline January & 9 & 12 & 14 & 25 & 4 & 12 & 4 & 3 & 2 & 0 & 0 \\
\hline February & 15 & 9 & 3. & 26 & 2 & 10 & 1 & 3 & 6 & 3 & 1 \\
\hline March & 12 & 10 & 2 & 24 & 3 & 7 & 1 & 3 & 7 & 3 & 0 \\
\hline April & 11 & 3 & 5 & 19 & 3 & 8 & 1 & 2 & 2 & 3 & 0 \\
\hline May & 8 & 3 & 7 & 18 & 4 & 7 & 0 & 2 & 2 & 1 & 2 \\
\hline June & 9 & 2 & 2 & 13 & 3 & 5 & 1 & 2 & 2 & 0 & 0 \\
\hline July & 7 & 5 & 8 & 20 & 5 & 8 & 1 & 2 & 1 & 2 & 1 \\
\hline August & -8 & 6 & 5 & 19 & 3 & 12 & 0 & 1 & 3 & 0 & 0 \\
\hline September & 8 & 2 & 6 & 16 & -6 & 1 & 3 & 1 & 5 & 0 & 0 \\
\hline October & 5 & 2 & 7 & 14 & 1 & 9 & 2 & 1 & 0 & 0 & 1 \\
\hline November & 12 & 8 & 10 & 30 & 2 & 9 & 2 & 7 & 2 & 3 & 5 \\
\hline December & 13 & 7 & 5 & 25 & 6 & 10 & 2 & 3 & 2 & 1 & 1 \\
\hline Total & 117 & 69 & 63 & 249 & 42 & 98 & 18 & 30 & 34 & 16 & 11 \\
\hline
\end{tabular}

Iinton B. Swift, "Declining Intake - Newly Revealed Needs", editorial in Highlights, Family Welfare Association of America publication, April 1941. 
Table XXXVI

Classification of Major Care Acceptances (Negro) for the Year 1940 According to New, Old, or Recurrent Status and According to the Major Problem Presented

\begin{tabular}{|c|c|c|c|c|c|c|c|c|c|c|c|}
\hline & & St: & 245 & & lass & fic & tion & of $\mathrm{P}$ & oble & mPre & ented \\
\hline Month & Jew & $1 d$ & Rec & Dot & Bcon & $\mathrm{Fam}$ & Com & Phys & Pers & Ment & Unk \\
\hline January & 7 & 3 & 1 & 11 & 1 & 7 & 1 & 2 & 0 & 0 & 0 \\
\hline February & 2 & 0 & 0 & 2 & 0 & 1 & 1 & 0 & 0 & 0 & 0 \\
\hline March & 2 & 0 & 1 & 3 & 0 & 2 & 0 & 0 & 1 & 0 & 0 \\
\hline April & 3 & 0 & 0 & 3 & 0 & 3 & 0 & 0 & 0 & 0 & 0 \\
\hline May & 0 & 1 & 0 & 1 & 0 & 1 & 0 & 0 & 0 & 0 & 0 \\
\hline June & 0 & 1 & 0 & 1 & 0 & 0 & 0 & 1 & 0 & 0 & 0 \\
\hline July & 2 & 1 & 0 & 3 & 1 & 1 & 0 & 1 & 0 & 0 & 0 \\
\hline August & 1 & 0 & 0 & 1 & 0 & 0 & 0 & 1 & 0 & 0 & 0 \\
\hline September & 0 & 0 & $I$ & 1 & 0 & 0 & 0 & 1 & 0 & 0 & 0 \\
\hline october & 1 & 2 & 1 & 4 & 1 & 3 & 0 & 0 & 0 & 0 & 0 \\
\hline November & 2 & 2 & 1 & 5 & $\underline{0}$ & 3 & 0 & 2 & $Q$ & 0 & 0 \\
\hline December & 3 & 0 & 1 & 4 & 0 & 2 & 1 & 1 & 0 & 0 & 0 \\
\hline Total & 23 & 10 & 6 & 39 & 3 & 23 & 3 & 2 & 1 & 0 & 0 \\
\hline
\end{tabular}

Tables XXXV and XXXVI indicate the major care acceptances for 1940 according to race, status of the application, and classification of the major problem presented. For detailed explanation of classification of problem presented see Appendix XVIII.

The small number of negro major care acceptances is noted. In 1939 the average monthly intake was five and in 
1940 it was four as compared with a monthly average of twenty-seven for white acceptances in 1939 and twenty-four in 1940. It was not possible to discern from record material causative factors. It was the opinion of one of the Negro staff members that as the agency was no longer primarily a relief giving agency, and as a large percentage of the negro group need relief, they now apply directly to the public agency. Because of various cultural factors the middle income group might correspond to the higher white income group and because of some relief connotation of the Family Service Organization this economically more secure group does not apply for service. There may also be some deeper psychological race factors involved. Those negro cases accepted presented predominantly financial or physical problems and problems evidencing lack of community resources. 
Statistics Compiled for Sample of 249 Major Care Acceptances (Negro and White) for $1939-1940$

Table XXXVII (see page 134) indicates that applicants were predominantly residents. The largest group of families had one or two children.

\section{Table XXXVIII}

Family Status of 249 Major Care Acceptances $1939-1940$

\begin{tabular}{|c|c|c|c|c|c|}
\hline Family & & 32 & 1 & 40 & \\
\hline Status & White & Negro & White & Negro & Tota \\
\hline Married & & & & & \\
\hline counle & 57 & 8 & 70 & 12 & 147 \\
\hline Common Law & 1 & 0 & 1 & 7 & 3 \\
\hline Unmarried & & & & & \\
\hline Couple & 0 & 0 & 2 & 0 & 2 \\
\hline $\begin{array}{l}\text { Jnmarried } \\
\text { Mother }\end{array}$ & 1 & 0 & 0 & 1 & 2 \\
\hline Widow & 4 & 2 & 5 & 2 & 13 \\
\hline Widower & 1 & 1 & 6 & 1 & 9 \\
\hline beserted & 2 & 2 & 0 & 1 & 5 \\
\hline Divorced & 6 & 0 & 10 & 0 & 16 \\
\hline Separated & 16 & 3 & 18 & 3 & 40 \\
\hline Single Man & 1 & 0 & 5 & 2 & 8 \\
\hline $\begin{array}{l}\text { Single } \\
\text { Woman }\end{array}$ & 0 & 0 & 2 & 1 & 3 \\
\hline Unknown & 0 & $\underline{0}$ & 1 & 0 & 1 \\
\hline Total & 89 & 16 & 120 & 24 & 249 \\
\hline
\end{tabular}

Table XXXVIII indicates that services of the Family Service Organization were given mostly to family groups rather than to single individuals. 
Table XXXVII

Identifying Information on Cases Read for the Years 1939 - 1940

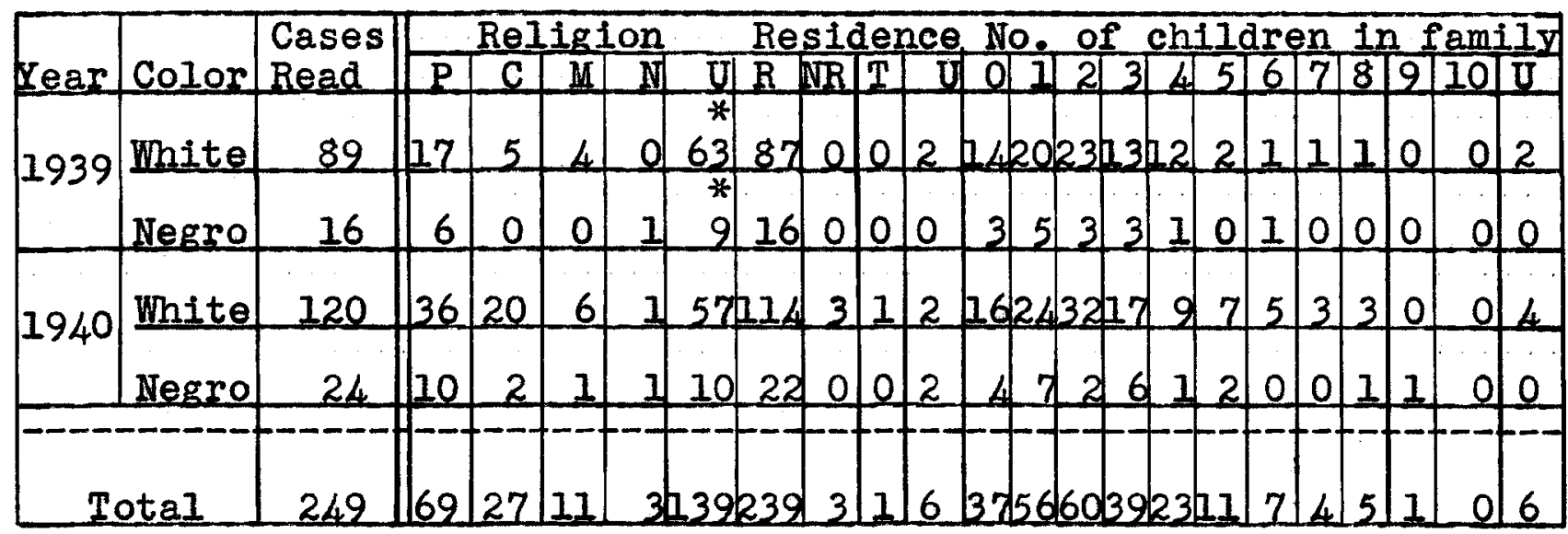

*48 of the 63 (white) unknown and 7 of the 9 (negro) unknown classification as to religion were cases accepted during July, August, and September 1939. Religion was not tabulated for these three months as this was not included in the statistics as gathered for a previous study from which statistics for that three months period are drawn for this study.

KEY: See page 86. 
Table XXXIX

Statistics Concerning Financial Status of Sample of 249 Major Care Acceptances, White and Negro, for 1939 - 1940

\section{A. Financial Status}

\begin{tabular}{|c|c|c|c|c|c|}
\hline Financial & \multicolumn{2}{|c|}{1939} & \multicolumn{2}{|c|}{1940} & \\
\hline Status & White & Negro & White & Negro & Total \\
\hline $\begin{array}{l}\text { Economicalily } \\
\text { Independent }\end{array}$ & 38 & 4 & 40 & 5 & 87 \\
\hline $\begin{array}{l}\text { Supplementary } \\
\text { Relief }\end{array}$ & 15 & 4 & 33 & 11 & 63 \\
\hline $\begin{array}{l}\text { Maintenance } \\
\text { Relief }\end{array}$ & 30 & 8 & 34 & 6 & 78 \\
\hline $\begin{array}{l}\text { Relatives } \\
\text { Supporting }\end{array}$ & 4 & 0 & 5 & 0 & 9 \\
\hline Unknown & 2 & 0 & 8 & 2 & 12 \\
\hline Total & 89 & 16 & 120 & 24 & \\
\hline
\end{tabular}

Table XXXIX

B. Income of Economically Independent

\begin{tabular}{|c|c|c|c|c|c|}
\hline \multirow[b]{2}{*}{ Monthiy Income } & \multicolumn{2}{|c|}{1939} & \multicolumn{2}{|c|}{1940} & \multirow[b]{2}{*}{ Iotal } \\
\hline & White & Negro & White & Negro & \\
\hline$\$ 25.00-50.00$ & 5 & 1 & 1 & 0 & 7 \\
\hline $50.00-75.00$ & 5 & 0 & 10 & 1 & 16 \\
\hline $75.00-100.00$ & 1 & 1 & 4 & 1 & 7 \\
\hline $100.00-130.00$ & 2 & 1 & 2 & 0 & 5 \\
\hline 200.00 & $I$ & 0 & 0 & 0 & 1 \\
\hline WPA & 5 & 1 & 5 & 1 & 12 \\
\hline $\begin{array}{l}\text { Savings } \\
\text { Amount Unknown }\end{array}$ & 1 & 0 & 2 & 0 & 3 \\
\hline $\begin{array}{l}\text { Unemployment } \\
\text { Compensation } \\
\text { Benefits }\end{array}$ & 0 & $\underline{0}$ & 1 & 0 & 1 \\
\hline Unknown & 18 & 0 & 15 & 2 & 35 \\
\hline Total & 38 & 4 & 40 & 5 & 87 \\
\hline
\end{tabular}


Table XXXIX

C. Income of Families

Needing Supplementary Relief

\begin{tabular}{|c|c|c|c|c|}
\hline & & $39 *$ & & 340 \\
\hline Income & White & Negro & White & Negro \\
\hline $1.25 \mathrm{a}$ day & & & 1 & 0 \\
\hline 3.00 a week & & & 1 & 0 \\
\hline $5.00-8.00$ a week & & & 2 & 2 \\
\hline $2.00-12.00$ a wreek & & & 3 & 1 \\
\hline 14.00 a week & & & 2 & 0 \\
\hline $18.00-23.00$ a week & & & 1 & 2 \\
\hline 20.00 a month & & & 1 & 0 \\
\hline 30.00 a month & & & 2 & 0 \\
\hline 60.00 a month & & & 1 & 0 \\
\hline IYA & & & 0 & 1 \\
\hline Unknown & & & 19 & 5 \\
\hline- & $=$ & $-=$ & 33 & 11 \\
\hline
\end{tabular}

*Insufficient information to tabulate.

$34.9 \%$ of the families accepted, or eighty-seven of the two hundred forty-nine cases as indicated in table XXXIXA, were economically independent. $25.3 \%$ or sixty-three of the two hundred forty-nine cases needed supplementary relief. $31.3 \%$ or seventy-eight of the two hundred fortynine cases needed maintenance relief. $3.6 \%$ or nine of the two hundred forty-nine applicants were supported by relatives. In $4.9 \%$ or twelve of the two hundred forty-nine 
cases the financial status was unknown. In proportion to the number of cases read there was a decrease in 1940 of families needing maintenance relief and an increase in the number of families needing supplementary relief. The number of economically independent families applying remained fairly constant for 1939-40. These findings would indicate that people applying to the agency are in the lower and lower middle income group. The income of a large percentage of the economically independent group, however, was not arailable in the application material. The chlef causes of need for supplementary relief, as indicated in the following tables, were inadequate income and inadequate support in instances where the man and wife were separated or divorced. Some requests were made on the basis of need for help with special items such as glasses, special diets, teeth, etc. There was no request for help in starting a small business venture, etc., as had been suggested by the Community Chest Survey Study as a possible area of service. This was undoubtedly influenced by a feeling of community pressure in view of the inadequate relief available through the public agency during most of 1939 1940.

Unemployment was the chief cause of need for maintenance relief. Again the large number of cases in which specific cause of need was not clear is noted. 
Table XXXIX

D. Cause of Need for

Supplementary Financial Help

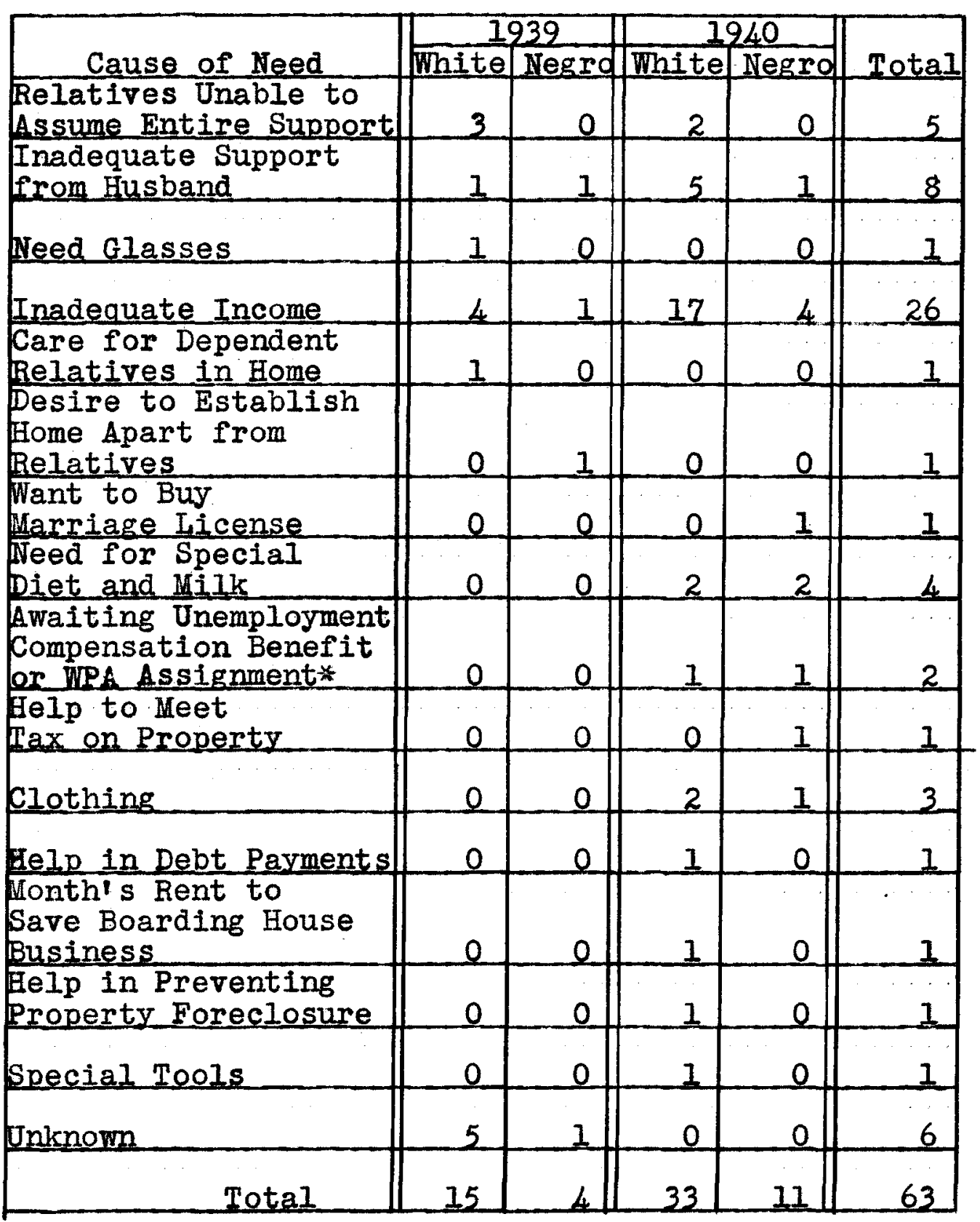

*WPA - Works Progress Administration 
Table XXXIX

E. Cause of Need

for Maintenance Relief

\begin{tabular}{|c|c|c|c|c|c|}
\hline & & 39 & & 940 & \\
\hline Cause of Need & White & Negro & White & Negro & Total \\
\hline Laid off WPA* & 1 & 1 & 2 & 0 & 4 \\
\hline Just out of Prison & 1 & 0 & 2 & 1 & 4 \\
\hline $\begin{array}{l}\text { Temporary } \\
\text { Unemployment }\end{array}$ & 1 & 0 & 0 & 0 & 1 \\
\hline Unemployment & 6 & 1 & 18 & 2 & 27 \\
\hline $\begin{array}{l}\text { Desire to Establish } \\
\text { Home Apart from } \\
\text { Relatives }\end{array}$ & 1 & 0 & 0 & 0 & 1 \\
\hline $\begin{array}{l}\text { Awaiting Unemployment } \\
\text { Compensation Benefit } \\
\text { or WPA Assignment* }\end{array}$ & 1 & 0 & 1 & 0 & 2 \\
\hline Man Incapacitated & 1 & 1 & 0 & 0 & 2 \\
\hline Illness & 1 & 1 & 1 & 2 & 5 \\
\hline Desertion & 0 & 1 & 2 & 0 & 3 \\
\hline Man in Prison & 0 & 0 & 1 & 1 & 2 \\
\hline $\begin{array}{l}\text { Loss of Income } \\
\text { from Property }\end{array}$ & 0 & 0 & 1 & 0 & 1 \\
\hline $\begin{array}{l}\text { Private Business } \\
\text { Enterprize Failed }\end{array}$ & 0 & Q & 1 & e & 1 \\
\hline Non-support & 0 & 0 & 4 & 0 & 4 \\
\hline Unknown & 17 & 3 & 1 & 으 & 21 \\
\hline Total & 30 & 8 & 34 & 6 & 78 \\
\hline
\end{tabular}

* WPA - Works Progress Administration 
Analysis of Source of Intake

Table XI

Source of Intake of 249 Major Care Acceptances (Negro and White) in $1939-1940$

\begin{tabular}{|c|c|c|c|c|}
\hline \multirow{2}{*}{\begin{tabular}{|l||} 
Source of \\
Intake
\end{tabular}} & \multicolumn{2}{|c|}{1939} & \multicolumn{2}{|c|}{1940} \\
\hline & White & Negro & White & Negro \\
\hline $\begin{array}{l}\text { Personal } \\
\text { Application }\end{array}$ & 51 & 8 & 57 & 6 \\
\hline $\begin{array}{l}\text { Referral by } \\
\text { Individual }\end{array}$ & 8 & 4 & 17 & 4 \\
\hline $\begin{array}{l}\text { Referral by } \\
\text { Other Agency }\end{array}$ & 30 & 4 & 46 & 14 \\
\hline Total & 89 & 16 & 120 & 24 \\
\hline
\end{tabular}

Table XII

Source of Intake $1939-1940$

A. Personal Applications

\begin{tabular}{|r|r|r|r|r|r|r|r|}
\hline Year & Color & Man & Woman & Wan \& & Child & $\begin{array}{c}\text { Un- } \\
\text { known }\end{array}$ & Total \\
\hline 1939 & White & 21 & 26 & 4 & 0 & 0 & 51 \\
\hline Negro & 3 & 5 & 0 & 0 & 0 & 8 \\
\hline 1940 & White & 23 & 30 & 3 & 1 & 0 & 57 \\
\hline
\end{tabular}

48.9\% of the two hundred and forty-nine interviews analyzed were made by personal application. It seems significant that the application was seldom made jointly by the man and the woman. Table XII indicates that the husband did not take the major responsibility as head of the 
household to make application for assistance as the wife took responsibility in more instances than the husband did.

The majority of the clients came to the agency with a relief request but with other difficulties involved besides the need for relief. In some cases it was evident that the need for relief probably precipitated the other problem, in some cases it was perhaps easier for the client to come with the relief need and he was seeking help in expressing other needs. For the most part the clients seemed to be most articulate about the relief need. Situations involving need for relief included help in questions of desertion, work plans, health problems, economic pressure bringing anxiety, emotional upheaval in facing unemployment for the first time, "nervousness" resulting from worry, non-support and resultant confusion as to what to do. Other situations involved care for children while the mother worked where her first impulse was to place the children, employment difficulties, inadequate wages, problems centering in alcoholism, requests to establish a home, couples separated because of financial pressure, and many others.

The client expressed other needs apart from financial needs. Some requested help with marital troubles, budgeting help and anxiety over indebtedness. Other requests were stated in terms of vague "nervous" symptoms; former clients returning to the agency for counseling and advice; help in plans for adolescents; availability of 
training resources in changing type of employment; plans for senile relative whose behavior was breaking up a home; housekeeping service. Other requests were broader such as "some kind of help", "help to get things settled", "help to get on feet", "help work out problems" and "help to get out of a rut".

These findings seem to indicate that the client usually made his request in terms of some concrete help. Coming to the family agency where there may be a wide variety of services available, the client often needed help in focusing his problem. As illustrated in the case previously cited of the nurse applying to the agency because of her panic about plans for confinement, it is realized that the client not only states a verbal request but his attitude, what he has done about his situation, the fears he has in asking for help -- all condition what help he wants and his capacity to do something about his trouble.

Thirty-three cases or $13.3 \%$ of the total two hundred forty-nine acceptances were referred by individuals as indicated in table XuII (see next page). The eight white referrals made in 1939 included requests for helping clients in relation to marital discord, anxieties over Works Progress Administration lay offs, budgeting help and financial need. The negro referrals were primarily on the basis of financial need. Of the seventeen white referrals in 1940, seven were referred primarily because of financial need, two for investigation of need. The remaining eight referrals 
Table XIII

Source of Intake $1939-1940$

B. Referrals by Individuals

\begin{tabular}{|c|c|c|c|c|c|}
\hline Source of & & 2939 & & 240 & \\
\hline Referral & White & Negro & White & Negro & Total \\
\hline Community Person & 3 & 3 & 4 & 0 & 10 \\
\hline City Health & 0 & 0 & 1 & 0 & 1 \\
\hline Relative & 1 & 1 & 3 & 0 & 5 \\
\hline Physician & 1 & 0 & 0 & 0 & 1 \\
\hline Minister & 2 & 0 & 1 & 0 & 3 \\
\hline Grocer & 1 & 0 & 0 & 0 & 1 \\
\hline $\begin{array}{l}\text { Agency Board } \\
\text { Member }\end{array}$ & 0 & 0 & 1 & 0 & 1 \\
\hline Probation officer & 0 & 0 & 0 & 1 & 1 \\
\hline Banker & 0 & 0 & 1 & 0 & 1 \\
\hline Employer & 0 & 0 & 2 & 2 & 4 \\
\hline $\begin{array}{l}\text { Former Agency } \\
\text { Worker }\end{array}$ & 0 & 0 & 1 & 0 & $I$ \\
\hline Mayor's Office & 0 & 0 & 1 & 0 & 1 \\
\hline Insurance Agent & 0 & 0 & 1 & 0 & 1 \\
\hline $\begin{array}{l}\text { Advisory Committee } \\
\text { Member }\end{array}$ & 0 & 0 & 1 & 1 & 2 \\
\hline Total & 8 & & 17 & & 33 \\
\hline
\end{tabular}

were made on the basis of need for other case work services including two referrals for budget planning, one for service to an adolescent, one for help with "personal problems" of the client, another because of mismanagement, another help for the client "to get on his feet", another 
help for a widower in making plans for a twenty-seven

year old feebleminded daughter. The referral made by a minister in December 1940 as needing "case work service" is interesting from the point of view of referral technique.

The minister referred the case by telephone stating that the woman had been attending his church and had come to him for help with her problem. The woman was upset over her husband's behavior. She and her husband could never plan together. He ignored her. She felt helpless to deal with the situation -- seemed completely 'licked'. She had asked the minister if she should go to Juvenile Court. The minister had asked the client to let him think the matter over for awhile to see if there was not some other way that she could work out her problem. The minister knew that the husband was antagonistic to the church and would resent the minister's help as interference. The minister showed appreciation of what casework help might do for the woman. Arrangements would be made by the minister to discuss possible services, which the Family Service Organization might offer, with the woman. (The worker receiving the referral outlined possible services and stressed the client's making application and wanting help.) An appointment would be arranged to see the client.

In this case there was a clear understanding between the caseworker and the referral source as to the reason for referral. On the other hand the decision as to how the agency might help was to be left to the client and the caseworker. The way was left clear for a report back to the referral source. An understanding as to agency function was clear between the worker and the referral source. Steps as to arrangements to interview the client were clarified at the referral source. The minister had indicated the possibility of a relief need but this was seen in relation to the larger problem presented.

It may prove enlightening to contrast the above re- 
ferral technique with the hendiling of a referral by a physician in 1939.

A physician telephoned concerning assistance for a distant relative. The man was unemployed but the physician saw other problems with which the agency could help the family. "Mrs. A. is pretty to look at but cannot manage the finances of the family." (The physician)feels that if we can help with this problem it will relieve all parties concerned. Mrs. A. comes from a mountain family of rather low standards. She had no training in managing at home. $\mathrm{Mr}$. A. was described as an 'industrious fellow' who does the best he can but he has no help from his wife. .

"We told $\mathrm{Dr}$. that we would make an appointment for Mr. A. to come to our office to discuss his situation and that we would notify him of the time so he could tell Mr. A. about it."

About three days later Mr. A. came to the office. He discussed his work record but in the process of the interview indicated none of the problems listed by the referral source. The worker indicated that she made some statement about $\mathrm{Mr}$. A's household management and Mrs. A's care of the children. MMr. A. did not recognize any problem here, apparently, and said that the children were getting along very nicely in school. One thing he would say for $\operatorname{lirs.~A~was~that~she~could~make~a~dollar~go~as~far~as~}$ anybody he knew." The worker explored possibility of relatives assisting, checked contact with the Municipal Bureau of Social Service and with the Unemployment Compensation Office. In discussing the case with the district supervisor as to reason for acceptance the worker stated, "Since $\mathrm{Mr}$. A. had not indicated a desire for services which (tre physician) had advised, it was questioned as to whether the family should be accepted". She further stated that in view of the fact that the physician thought the worker coudd be of some service to the family and after getting into the home the worker might discover other ways of helping the family.

There was no understanding with the client or with the referral source as to why the case was accepted. There was no understanding with the referral source as to use of the information he gave in relation to clarifying the referral with the client. The client had no opportunity to share in deciding whether he wanted the help of- 
ferred. The service was imposed on the client in the guise of relief which the client saw as the problem.

The variance in the techniques of handling referrals made by individuals are evident in the two examples cited. They seem to indicate the need to have clear understanding between the referral source, the client, and the worker as to what help the client wants and how the agency might help. As this understanding is made clear in relation to individuals referring cases there is the opportunity to interpret agency function and the realization that the agency cannot force services. The agency recognizes responsibility to the client in interpreting "the helping process" to him and to the referral source. $37.8 \%$ of the two hundred forty-nine cases were referrals from other agencies (see table XIIII, page 147). A review of the situations referred by these agencies will provide a picture of how these agencies used the Family Service Organization. The Louisville City Hospital referred the largest number of cases. The social service department of the hospital referred nineteen of the cases and the department of psychiatry referred five. Referrals by the social service department included requests in twelve instances for financial help, with other service needs implied. Seven of the referrals entailed no relief request. These involved help with marital troubles, study to clarify the problem, guidance and supervision of young couples, "preventive work and advice", and helping a fam- 
Table XIIII

Source of Intake - Sample of Cases 1939 - 1940

c. Referrals by Other Agencies

\begin{tabular}{|c|c|c|c|c|c|}
\hline & & 32 & & 240 & \\
\hline Agency Referring Cases & White & Negro & White & Negro & Total \\
\hline $\begin{array}{l}\text { Louisville City Hospital - } \\
\text { Social Service }\end{array}$ & 6 & 2 & 6 & 5 & 19 \\
\hline $\begin{array}{l}\text { Louisvilie City Hospital - } \\
\text { Department of Psychiatry }\end{array}$ & 1 & 0 & 4 & 0 & 5 \\
\hline Juvenile court & 4 & 1 & 9 & 2 & 16 \\
\hline Christ Church Cathedral & 2 & 0 & 0 & 0 & 2 \\
\hline Legal Ald Society & 3 & 0 & 5 & 1 & 2 \\
\hline Central State Hospital & 1 & 0 & 2 & 0 & 3 \\
\hline Mental Hygiene Clinic & 3 & 0 & 3 & 0 & 6 \\
\hline National Youth Administration & 1 & 0 & 1 & 1 & 3 \\
\hline Penitentiary Inquiry & 0 & 0 & 2 & 1 & 3 \\
\hline Out of Town Inquiry & 1 & 0 & 1 & 0 & 2 \\
\hline Waverly Hills & 1 & 0 & 1 & 0 & 2 \\
\hline Ormsby Village & 1 & 0 & 0 & 0 & 1 \\
\hline Children's Free Hospital & 0 & 0 & 1 & 0 & 1 \\
\hline Children's Agency & 3 & 0 & 1 & 1 & 5 \\
\hline Works Progress Administration & 0 & 0 & 1 & 0 & 1 \\
\hline $\begin{array}{l}\text { Municipal Bureau of } \\
\text { Social Service }\end{array}$ & 2 & 0 & 1 & 2 & 5 \\
\hline Presbyterian Colored Mission & $\underline{0}$ & 은 & 0 & 1 & 1 \\
\hline Travellers Aid Society & 1 & 0 & 0 & 0 & 1 \\
\hline Central Louisville clinic & 0 & 1 & 0 & 0 & 1 \\
\hline Community Chest Complaint & 0 & 0 & 3 & 0 & 3 \\
\hline Inter-agency Conference & 0 & 0 & 1 & 0 & 1 \\
\hline $\begin{array}{l}\text { Louisville } \\
\text { Goodwill Industries }\end{array}$ & 0 & 0 & 1 & 0 & 1 \\
\hline
\end{tabular}


Table XIIII, cont.

\begin{tabular}{|c|c|c|c|c|c|}
\hline & & 339 & & 240 & \\
\hline Agency Referring Cases & White & Negro & White & Negro & Total \\
\hline $\begin{array}{l}\text { Young Women's } \\
\text { Christian As sociation }\end{array}$ & $+4=0$ & $3+40+4$ & $1+1+2+0$ & 0 & 1 \\
\hline Home for Crippled Children & 0 & 0 & 1 & 0 & 1 \\
\hline Weighborhood House & 0 & 0 & 1 & 0 & 1 \\
\hline Total & 30 & 4 & 46 & 14 & 94 \\
\hline
\end{tabular}

ily to adjust to having an invalid in the home. The department of psychiatry referrals involved, for the most part, helping patients who had been on the psychopathic ward for observation to readjust in the home situation. In one instance the referral was made on the basis of establishing a young girl apart from her relatives as the difficult home situation had precipitated her illness. In other cases the agency service was seen in terms of giving stabilizing care to the husband or wife whose spouse was being sent to Central State Hospital.

The Juvenile Court referred the next largest group of families, sixteen out of ninety-four referrals. In 1939 requests were primarily financial. In 1940 there were requests for other services in the area of marriage counseling, adolescent problems, and supervision of care of children.

Christ Church Cathedral referred two families, one for study of the family situation to determine underlying causes of need and to secure an estimate as to po- 
tentialities of treatment. The other case involved financial planning.

Referrals from the Legal Aid Society centered in the field of marital discord. (The agency has a cooperative service with the Legal Aid Society wherein a worker from the Family Service Organization goes to the Legal Aid Society on certain days and interviews clients who the lawyers believe may need the help which a family agency can offer.) The referrals were made particularly in relation to applications for divorce where the client seemed undecided what to do or desired reconcillation. Some requests centered in working out trial budgets to determine ability to meet certain financial obligations.

Referrals from the Central State Hospital were made primarily in relation to the Family Service Organization's assisting patients being dismissed from the hospital in readjusting outside of the institution. One worker took all referrals from Central state Hospital as a special project.

The Mental Hygiene Clinic referrals stressed study of the family situation where home conditions were influencing a child's behavior in a negative way. There was usually evidence that the problem was with the parents and other members of the family rather than with the child.

The National Youth Administration referrals were made on the basis of help for adolescent youths in adjusting to rather difficult home situations. These referrals 
did not stress relief need.

The five referrals from the Children's Agency centered in requests for guidance and counseling in home management and in marriage counseling. Some of these requests involved relief but only as incidental to other services.

The five referrals from the Municipal Bureau of Social Service were primarily cases in which the man or woman was not considered employable because of inability to adjust on a job.

As the other agencies referring cases, referred such a small number, the situations will not be reviewed here in detail. All of these referrals were made on a definite case work basis except the referral from Ormsby Village which seemed to be for temporary financial help only. From the comparatively small number of referrals from the majority of the referring agencies one questions that the services of the Family Service Organization are being used nearly to capacity and whether there is not a field for more consultative service.

The method of referral of cases from other agencies was either by letter, telephone, or in conference. In any case the referring agency sent a summary of its contact. When a case was accepted in a case conference between the agencies, the client was often not seen until after the case was accepted. (The case supervisor represents the agency in inter-agency conferences.) often referrals were 
handled by giving the client an appointment and basing acceptance of the case on the interview with the cllent. In referral from another agency the referral process was not always clear to the client and he was often confused as to what help he wanted from the agency and what the agency had to offer. The following case is illustrative of referral process.

On 3-16-39 the medical social worker in the pediatric clinic at the City Hospital discussed the case from the point of view of possible referral and agreed to send a letter of summary.

On 3-28-39 the summary letter was received. The seven year old child in the family was being followed in heart clinic. The mother had come to the medical social worker on 3-15-39 regarding her domestic problems. She was employed as a stenographer earning $\$ 65$ a month. Her husband was irregularly employed. There was another child, nine, in the family. The seven year old patient had been in the hospital and upon discharge a WPA housekeeper was placed in the home as the mother was out of the home working. The housekeeper was withdrawn after talking with the medical social worker. The husband was highly sexed and had attempted to have relations with the nine year old daughter. The mother gave the history of the difficulty saying she had never been able to talk with anyone concerning the situation until she came to the medical social worker. She expressed the desire to talk the matter over with a psychiatrist as she had gotten so much relief by unburdening her problem to the medical social worker. The medical social worker advised her "that this could be arranged but suggested that an agency such as the Family Service Organization would be most helpful in working out her problems with her. She did not seem to accept this suggestion, -- we later learned it was because she knew several people in the employ of the Family Service Organization central office. We tried to alleviate this fear by saying her contacts would be wholly with the district office and that she need not fear any contact with her friends."

The medical social worker gave a brief review of the present situation in the family. The woman was contemplating leaving her husband and boarding herself and the two children with a friend. The woman was desirous, however, of continuing to live with her husband whom she said she loved but she could not endure going on with him see- 
ing another woman. "She has faced him with the situation and has told him that she is willing to see a psychiatrist and learn if she is not partly responsible for this incompatability."

"The mother is very protective over the relations of the father and the child and asked that this be kept confidential." A neighbor was caring for the children at present.

The mother impressed the medical social worker as a "highly emotional individual who has finally faced her situation. She is intelligent and is willing to follow any suggestions. We are contemplating referring her to you upon our next contact. The psychiatrist with whom we have conferred, believes that the mother should be studied in the psychiatric clinic. We will be glad to arrange this if necessary. We are, therefore, sending you this summary so that you will have the information in hand when she visits your office."

On 4-19-39 another letter was received from the medical social worker, stating that since her last letter she had seen the mother on only one occasion at which time she stated that she did not feel she was in need of any service from a family agency. "She had on her own initiative separated from her husband and had moved in with her two children to live with a friend and her family. She did not disclose her new address at the time. Her domestic situation had evidently cleared up so well that she did not feel it was necessary for her to go to see a psychiatrist although she agreed to bring her daughter in for consultation with a child psychiatrist.

We feel that it is unwise to force any issues with this mother this time but are certain that she will return for advice in the near future. We are, therefore, advising you of the present situation inasmuch as we feel that she will be requesting your service soon."

On 5-4-39 the medical social worker telephoned to refer the client. The client had come in to talk with the medical social worker and was quite upset about the situation. The arrangement made to live with friends was not working out satisfactorily. The client was upset as to what she wanted to do and was anxious to talk with someone. "We made an appointment to see the client in the Social Service department office of the City Hospital on Saturday afternoon.

worker) met (the client) in the Social Service department 
at the Louisville City Hospital Saturday afternoon. She works and it was impossible for her to get off during working hours. She said (the medical social worker) thought she had a big problem to talk over with someone and she herself wanted to talk about this problem. What she needed was someone to consult with and advise her. We said we did not know just what explanation the medical social worker had made of the Family Service Organization but we would be glad to talk with her and try to help her see what help she wanted." At this point there was discussion as to the client's not wanting to go to the Family Service Organization main office. Arrangements were made to meet her on noon hour at the YWCA for future appointments. This preliminary discussion seemed to put the client at ease.

"We asked the client to tell us a little about her troubles so that we might better understand what help she wanted. She replied hers was a long story and she did not know quite where to begin to let us know about the troubles. We said the Medtcal social worker had told us a little about the situation. The client quoted the medical social worker as saying we would understand her wanting to ask help and we would be glad to consult with her what to do."

The client told her story, given some direction.

"We said the client did have a problem and was torn between her place as a wife and a mother and in her feeling for her husband. She still has affection for him and as her husband she loves him, yet when she thinks of things he has done she hates him". . . .

- " "The client asked if wo felt she had done the right thing and what should she do now? We asked what she felt we might do? We realized she was too confused in her thinking to know. She vaguely said 'if something should happen' we would know about her trouble -- the 'anything' she qualified as meaning the loss of her job. Her feeling of insecurity was evident. We mentioned her wanting to see a psychiatrist. She replied she thought a psychiatrist might approach her husband but she didn't believe this possible now. He 'flew off' at anyone who 'found him out' and tried to talk to him. She thought maybe sheld like to see a doctor at the psychiatric clinic if this seemed best for her". . . .

". - We suggested that we meet and talk a few times to help her decide in her own thinking what she wanted to do and what help she wanted. We mentioned consulting the Mental Hysiene Glinic. She would like to think 
through some of these things. The present living arrangement was not satisfactory but she wanted to stay where she was until school was out.

She is worried about budgeting the $\$ 65$ a month income and mentioned trying to budget to get milk for the children. As we had been talking for over an hour, we suggested discussing this in our next interview."

The process of referral is clear. The referring agency is clear in the reason for making the referral and had interpreted the agency function to the client. The client was not referred to the Family Service Organization until she was ready to come. The referral source did not push the client or attempt to impose a service because of the evident problem. The referring agency kept the family worker informed as to progress of referral and saw that the information concerning the hospital contact was available to the family worker before the client was seen. One had the impression that the client had been prepared for the referral so that the bridge from the medical social worker to the family social worker was a natural one. The client came with confidence in the family worker. The family worker made use of referral information and used this to help the client focus her problem. The worker let the client express the problem in her own way, however, and gave the client a feeling of mutually participating in a beginning helping process. The link to previous contact was recognized in referring to possible referral to a psychiatrist. This was also held out as a possible part of further treatment plans. One had a sense of treatment pro- 
cess begun. There had been no sharp break in the helping process begun when the client first went to the medical social worker with her problem.

This case illustrates the technique of a gradual acceptance process, gearing activity in terms of the client's desire to face his problem and to do something about it. Is the agency at times inclined to be too abrupt in accepting cases? Particularly in relation to referrals from other agencies is there a lack of clear understanding of the client's part in the referring process? In a referral situation there are three persons involved: the client, the referral source, and the intake worker receiving the application. As each understands and accepts his responsibility, the process is clarified.

Meeting the need of the client who makes his own application and the client referred by another agency or individual, involves differing techniques, yet in both instances the client should have the right to participate. Increasingly one sees a shift in emphasis from the agency's view of the application process to its meaning for the client.

It seems that there is opportunity for the gradual acceptance process of a case in relation to the cases which were accepted for "clarification", "exploration", nfurther study", "investigation", or "evaluation of treatment possibilities". All of these reasons for acceptance 
imply that there was need for some further study before a decision could be made as to what help the client could use or what help the agency might offer. As has been indicated previously, the caseworker must at times take the initiative in guiding the presentation of material by the client. May not two or three interviews be necessary for some clients to assimilate this direction before they can focus their problem? A first interview that is too long may force the client to an over-participation and a hesitancy to return to the agency. Several specific case situations will serve to illustrate that caseworkers in the Family Service Organization have been accepting cases for continued study but this reason for acceptance was often vague to the client. The worker was "exploring" without the client's mutual awareness of this experience of thinking together with the worker about his difficulty.

1) The family was referred by the head worker at the Neighborhood House (settlement house). The man in the home left periodically but his wife did not regard these absences as desertion. Yet she was disturbed by the man's behavior. She seemed overly protective of him. The head worker thought that both the man and the woman would respond to casework treatment. There was also financial need as the man was now out of town. The head worker thought that if the immediate financial need were met, the caseworker would be able to gain the woman's confidence.

The caseworker saw the client by appointment and it was evident that the client saw her need as financial. In view of the information given by the referral source the case was accepted on the basis of nexploration for one month" to define the client's difficulty.

2) This case was accepted by the Family Service Organization worker who saw applicants referred by the Legal Aid Society. The woman had applied at the Legal Aid Society for a divorce but the lawyer thought she was undecided as to whether or not she wanted a divorce. The man was alcoholic, abusive, and non-supporting. Two older adolescent sons were bringing pressure on their mother to 
take some action against their father. Because of the woman's conflicting feelings and indecisions, the case was accepted to "explore the situation further".

3) The Louisville Goodwill Industries referred a man with one leg. The man had a wife and children to plan for. He owned property and as a resilt of the accident which crippled him he was to receive a substantial cash settlement. The Louisville Goodwill Industries saw the man as having no comprehension of the value of money and little planning ability. There was the possibility of his securing trade training through the State Rehabilitation department if he could secure carfare, etc. There was the possibility of helping him plan expenditure and management of the settlement from the accident. The case was accepted for "exploration and further study".

4) This case was accepted for study. A widower whose wife had died recently was keeping a twelve year old daughter at home to do the housework. The worker commented that the client was too confused over his wife's death to be planful.

It is noted that in each of the above examples when a case had been accepted for exploration or study the client had not participated in deciding that the case be accepted for study. The client had not seen the same problem that the worker or referral source had seen. In only one of the examples cited was any time limit set as to the length or goals of the exploratory process. It would seem that as skills at the intake desk are refined and the intake worker is able to help the client express his need and the worker is able to define agency function in relation to this need, there will be fewer and fewer cases accepted as for general exploration as to service needs. The case may be accepted on the basis of only one need, leaving for the next worker or for future contacts the exploration of other service needs. There may be indication 
for more use of a gradual intake process -- not expecting a client to be able to make an immediate decision but extending the process over several interviews. Is there not an area for development in the caseworker's saying to the client, "I don't know just how we might help you; won't you come back and talk with us further?" Does the worker need more confidence in expressing doubt? 


\section{Problems Presented in the Intake Interview}

In analyzing requests brought to the Family Service Organization for service, one is aware of the breadth of the range of problems presented. These problems centered in difficulties arising in areas of marital discord; of strains and tensions developing in the family group because of two families living together; of concern over indebtedness and need for budget planning; of stresses of poor work adjustment; of health problems causing gradual family breakdown; and of conflict arising in the parentchild relationship and in conflicts of the adolescent. Problems presented range from economic, environmental disturbances to the deeper, inner personality maladjustments where referral to a psychiatrist may be the best treatment plan. The Family Service Organization in attempting to meet these problems in 1939 and 1940, steered a middle course between concentration on the economic and the deeper therapeutic need. 
Services Offered in the Intake Interview

The Family Service Organization offered a variety of services. These services ranged from a general listing of areas in which the agency might offer service to the specific meeting of the need in terms of the client's request.

Two major types of services seemed inherent in the helping process offered by the Family Service Organization. The one type of service was concerned with the tangible things the intake worker might offer the client. These included offering financial help, facilitating cooperation with clinics, helping with budgeting plans, seeing relatives and employers concerning better adjustments for the client, securing a Works Progress Administration housekeeper, making contact with other agencies such as settlement houses, old age assistance office, etc. In relation to cllent requests the offer of financial help was one of the most tangible services offered. In 1939 one frequently found a statement by the worker to the client that the Family Service Organization did not have much money for relief, that the Family Service Organization was not a relief agency, that the Family Service Organization did not give relief for long periods of time. This period of vague definition of relief function was indicative of the struggle to define the newer service emphasis apart from the traditional major relief function. Later in 1939 and 
in 1940workers at the intake desk were gradually developing skills in being more positive at the intake desk. To say what the agency could not do was being supplanted by a trend to offer relief service to the client in relation to the needs he was presenting.Vagueness as to the meaning of temporary relief was generally supplanted during 1940 by the newer consideration of the setting of time limits by the worker and the client in relation to agency function. For example, a young man applied for temporary supplementary relief. He was working in a broom factory making inadequate wages. The work was injurious to his health as he had suffered from bronchial asthma since he was a boy. He requested relief until he could get a better job. The worker saw this case as a posstble long time relief situation unless causal factors were studied. By asking a number of leading questions she helped the client think about some of the factors involved in his request for relief. What were his plans? What kind of job did he want to get? As the client thought more planfully of his needs, the worker interpreted the giving of temporary relief in terms of a time limit of six weeks to two months for the agency to give temporary relief and for the client and the worker to consider possibilities of the man's changing his trade which was injurious to his health, for the client to secure medical attention, to investigate possibility of moving to a relative's farm, of budgeting income, etc. The client came with an indefinite request for 
relief, but after securing help to focus his problem the client was able to see his way clear to act. The setting of time limits was explicit in the helping of the client to meet the underlying causes of his need for relief.

The intake interviews read often show evidence of the worker's clinging to the use of the more tangible relief service as the basis of "getting into" a case to explore needs. (In the above case the client understood the basis of relief giving.) Again in 1940 one sees this tendency decreasing in favor of the attempt to evaluate possible areas of treatment during the intake process, with relief only one of the possible areas where help may be needed.

The second type of service offered at the intake desk was concerned with the more intangible helping processes. These intangibles were expressed in various ways such as giving the family "a lift over a difficult period", helping to "clear up worries and conflicts", helping to "work out problems", "someone to talk to", offering "security", a vague "helping young couples". These services were characteristic of intangible help offered in 1939. In 1940 a significant trend seems evident toward a less vague use of intangible services. The concept of the client-worker relationship at the time of the intake interview and their mutual thinking and talking together to see what the client wants and how the agency can help was evident in many intake interviews. There was less gen- 
eralization as to help available. Release of tension, service of someone to talk to, the agency as a "buffer" and a "stand by", etc. were not merely verbalized but in many instances were demonstrated as the beginning of a continuing helping process. It was noted that there was little setting of time limits in relation to the more intangible services except as sometimes stated to a client, "Let's talk together for several interviews".

As the service so often offered to a client was in terms of having someone to talk to -- an nobjective outsider", it seems that specific case material may be illuminating.

1) The case was referred by the Mental Hygiene Clinic for the Family Service Organization to see what the real situation was in the home, and where the problems lay. The fouryear old boy was attending the liental Hygiene Clinic nursery school. The mother in talking about the boy seemed upset over marital difficulties. Financial need was a complicating factor. The rental Hygiene Clinic thought the woman needed "someone to talk to".

2) The case was referred by the Social Service department of the Louisville City Hospital outlining that the woman needed and wanted "someone to talk to". She was evidencing emotional difficulties complicated by pregnancy. She seemed to be rejecting her children.

3) This case was also a referral from the City Hospital. The client's child had been ill in the Hospital and the parents were upset about taking the child home. Both the mother and the father worked outside the home. The father feared the loss of his business and was in a quandary what to do. He needed "someone to talk to".

4) The case was referred to the Family Service Organization by a telephone call from the National Youth Administration office requesting service for a young girl twenty-one years old. She was so distressed about her own plans that the National Youth Administration project super- 
visor doubted that National Youth Administration placement would help her much. Her parents were separated and she was with friends until her father who was out of town could send for her. Her mother was mentally ill. The girl was emotionally disturbed and cried frequently throughout the interview. The worker recorded -- "We spent some little time helping (the client) decide whether she wanted the social worker to talk to, and she seemed to have no imagination or actual knowledge of how she might be assisted in this way. We said that the National Youth Administration supervisor had told her a little bit about how our agency helps people work out plans of different sorts, that in the main we worked with families and young men and women who needed some help in deciding what they wanted to do and how they were going to work things out. We felt that since she was uncertain as to whether she could get work that we might be of some assistance to her in that line, perhaps suggesting places for her to apply, perhaps making some contact for her which she could not make herself". . . "She seemed a little apprehensive about the procedure of having a social worker, so we explained in detail how workers made contacts, that is with office interviews on an appointment basis". . "We said we thought it was for her to decide whether she wanted a worker who would be somewhat of a stand by for her, helping her make contacts, etc., and being available if she wished to talk over plans with her".

\section{In the first of the four case incidents "someone to} talk to" seems to mean need for help in focusing and clarifying what the problem was. In the second example "someone to talk to" implies need for release of tension and someone to act as a sustaining force. In the third example "someone to talk to" implies helping the client out of confusion. In the fourth case example the caseworker gives some explanation as to what it means to have a caseworker to talk with, implying the worker is available in a sustaining role. The tone of the interview sets the pace for a relationship in which the worker acts as a counselor and guide and someone to whom the client can turn for assurance. In other cases read the offer of "someone to talk to" was used 
as a therapeutic tool to help the client to understand himself.

There were several gaps in services offered to meet needs presented. This was particularly observed in relation to children's problems such as truancy and methods of discipline; unemployment difficulties, particularly in relation to the client's losing his job because of some personal difficulty or fault of his own; and the problems of the ex-convict. Statement of the problem was clear, particularly in the diagnostic recording by the worker. There is Iittle evidence of a satisfactory approach to these problems or of attempts to face issues involved in the intake process in these cases. 


\section{Reasons for Acceptance}

In analyzing reasons for acceptance of a case, it is recognized that problems presented and services offered are inherent in the reason for acceptance. This is mentioned as a separate area for consideration, however, as the reason for acceptance was usually clearly stated in record material. It was possible to discern major areas of reasons for acceptances of cases. This does not mean that cases were accepted specifically for one reason. Several of the following reasons for acceptance might have been included in one case. The areas of acceptance are isolated as follows to give emphasis to the findings.

Temporary financial help: Specifically within this group were those cases accepted to meet the immediate financial need and to use this opportunity to help with other problems later; to help young couples get a start in a home of their own; to encourage health care; to establish a family apart from relatives; to give a family a lift where financial pressure was causing family tensions. In December 1939 and January 1940 cases were accepted for temporary relief where the wage earner had the definite promise of a job within a few weeks. As a whole, financial need was seldom the sole reason for acceptance.

Budget help: Help in household management, planning debt payments, and avoidance of further indebtedness was 
another area of acceptance. The Community Chest study pointed out the adequacy of relief planning service. Budgeting service seemed a natural corollary and many families were served in this way. One example will serve as illustration of this point.

A woman depending on income from boarders applied for help with a month's rent. During the winter her expenses had been unusually high and she was behind in rent payments. Her husband had been a patient at Waverly Hills Tuberculosis Sanatarium until recently and now could do only light work. In talking with the client the worker realized that the woman was seeking help in budget planning and helped the client recognize this need. Basis for further contact was started in the worker and the client together working out a budget. Discussion of other problems was incidental to the major budgeting help request.

Supervision: Other cases were accepted for "Supervision" in some area of service -- supervision of planning with a young couple, supervision of the care of children, supervision of household planning. The term "supervision" covered a broad range of services and was perhaps erroneously used in the more rigid meaning of supervision.

other areas of reasons for acceptance: A small number of cases were accepted for administration of relief furnished by a church, a former employer, other individuals or relatives. Other cases were accepted to meet special needs; to meet anxieties, tensions; and to understand personality difficulties such as helping a client to know what he wanted to do and to act on his decision. There were some cases accepted on a preventive basis where difficulties had not become clearly developed. There were various cases accep- 
ted partly because of the nature of the group in which the client found himself -- the ex-convict (the Family Service Organization has a special ex-convict fund), the patient to be dismissed from the Central State Hospital, etc.

Cases accepted on basis of former contact with the Agency: Former agency contact with the client was used in several ways which are indicated in the case illustrations which follow. In some instances the worker used previous contact with the client as a basis of reevaluation as to what help the client wanted from the agency. In others the worker measured the client's growth or lack of growth in relation to present application and previous contact. In other cases the previous contact was used as a starting point for redefinition of agency function.

In the first case illustration the client was seen by an intake worker who had not known the client during the client's previous contact with the agency. In the second case illustration the client was seen by the worker who had formerly been the worker when the case was last active with the Family Service Organization.

1) The case had been known to the Family Service Organization from 5-8-39 to 10-31-39, having been referred to the Fanily Service Organization by the Louisville City Hospital department of psychiatry. The client was being seen by the psychiatrist who thought that the Family Service Organization could help in carrying out treatment plans with the family. The husband drank and was demanding sexually. There was some financial need. The psychiatrist thought the woman needed supportive casework help and that the caseworker could be helpful in interpreting the woman's 
needs to her husband. The man refused to see the caseworker and the entire Family Service Organization contact was with the woman. There was a noticeable easing of tensions and growing planfulness.

In closing the case the worker stated, "(The client) may return to the Family Service Organization for service. She seems to be an intelligent person and one who is able to share in a casework relationship. There seems to be some indication that (the husband) will never be able to earn much more than he is now. Because of this it might be advisable to approach any relief plan carefully."

On 3-15-40 the woman returned to the office and asked to see her worker. When told that she would have to make application through the intake department she was confused as previously the first appointment had been arranged through the hospital for her to see the caseworker who continued with her case. She was given an appointment for 3-I640, could not keep this appointment and was given another for $3-18-40$.

On 3-18-40 Mrs. W. (the client) "came into the office at the appointed time. She was dressed neatly in black. She was apparently quite at ease and throughout the interview spoke in a quiet, well-modulated voice. One was impressed by her casualness, yet at the same time had the feeling of an underlying tenseness at times. When we asked how she felt that we might help her, her first response was that they needed help financially. We asked if things were very different since she had talked with Mrs. _- (former worker), and she replied, 'not very different'. She said that she had been going to the gynecology clinic but had not been going to see Dr, or or Dr. o o (psychiatrists in psychiatric clinic at the Louisvilie city Hospital). Saturday morning, when she had gone to the clinic, she had gone upstairs to see Miss (worker in psychiatric clinic). Miss had suggested that she talk with someone from the Family Service Organization. She thought maybe she would like to go to talk with either of the psychiatrists again. We asked whether she had been feeling worse lately. She said that she had not been feeling very good. We asked whether things were any better between her and her husband. She smiled and said they were about the same as usual. His work is not so good and that always makes things worse. She seemed vague as to amounts her husband made, not with any attempt of concealing facts but rather that she just did not seem to know. She said even when work was good, her husband did not make over twelve dollars a week. Now she did not think he was making over eight dollars. He is still driving a truck. Last week he gave her only three dollars. It is always up to her to 
manage things.

"We asked how they decided who was to take the responsibility for doing something about the inadequate income. Mrs. W. repeated that this was left up to her. If she did not come, the children would suffer. When we asked if she and Mr. W. ever worked out plans together, she said they usually spent the money as it came. One had the feeling of very little planning between the two. We wondered if they had any sort of agreement about working together when they were married. The client said then both of them were working and it did not seem to be a particular problem. We wondered whether Mr. W. still wanted to see no one representing an agency, and whether he ever thought of the future as far as his family was concerned. Mrs. W. brightened a little at this and said that $\mathrm{Mr}$. W. had talked quite a lot about some day hoping to have a truck of his own. The client commented that her husband is a good worker. We felt that this was one point at which the husband might come nearest to considering talking over common interests. We suggested this to the client, that sometimes we were able to offer help in getting families started in business, maybe something could be worked out for them. The client nodded questioningly, as if to say she still had doubts as to how cooperative $\mathbf{M r}$. W. might be. She had returned to our question about agreements made at the time they were married, remarking that such plans had never occurred to her then. She had been 'dumb about many things'.

We said the client had seemed to want to come in and talk with Mrs. (former worker) when she was the worker. The client was then able to express quite clearly how much it had meant to her to have someone with whom she could sit down and plan. Her husband only thinks it is foolishness for her to go to the City Hospital clinfo. One had the feeling that the client needed an understanding person with whom she might talk over the many conflicting thoughts which she evidently has. At this point we asked whether she had returned to the Maternal Health Clinic. She said that she had not. She said, continuing in the same tone of voice, that she believed she is three months pregnant. We asked her how she felt about this. She said she did not feel good about it. We asked how her husband felt. She said it seems to make no difference to him. When we mentioned calling the social worker at the Louisville City Hospital the client thought this might be well but wondered whether it would take a long time. She did need milk and coal, but maybe only for a week, like she did before. Then she would like someone to talk to about things. We suggested that we would write her a letter either today or the following day telling her who her worker would be and arranging an appointment time. We felt that in view of the previous contact, that Mrs. W. had experienced caseworking service and that she was asking for a continuation of this help." 
This case illustration indicates the difficulty a client may experience in reapplying to a new person in the agency. This also indicates the confusion that a client may feel in having to be seen by several workers before the case is accepted. I In this particular case the client came to the agency expecting to continue the relationship of the previous contact. Making application was a new and fearful experience to her (as in the previous contact all arrangements had been made through the referral source for the client to see a worker in the agency) and she was resistive. The intake worker was able to relieve her confusion about the intake process by making use of material relative to the client's previous experience of casework

As each worker is at the intake desk only a half a day a week and as most of the intake work is centered in the application department this means that a client or a person referring a case often talks with two or three workers before a case is accepted. For instance, one worker will receive a perhaps lengthy referral call and will schedule an appointment for a worker at the intake desk to see the client. The client may not keep the appointment but will call in later and be scheduled to see another worker. This worker may have to call the referral source for further clarification or report back. It is possible that if the case is accepted it would be carried by a fourth worker. This same process may hold true in a lesser degree in personal applications where an appointment is given by one worker, the client interviewed by a second worker, and the case carried by a third worker. There would seem to be less confusion for the client and for the referral source if the worker first seeing the client by appointment could follow through on the case. It would also seem that this would provide more opportunity for intelligent interpretation if a referral call involving detailed referral information could be handled by the person receiving the call. 
help from the agency. At first her request was financial but by asking some direct questions and securing a little history the worker was able to lead to exploration of the client's evaluation of previous contact with the agency. The worker did not seem to expect the client to verbalize too much.

2) The case had originally been known to the Family Service Organization from 12-20-38 to 12-27-39. The case had been referred by the Juvenile Court and the Mental Hygiene Clinic as the delinquency of the twelve year old boy seemed to be an outgrowth of difficulties within the family group. The mother, during contact with the Family Service Organization, was seen as an ambitious person having ideals which she could not meet in reality. The father was a slow, plodding person. The mother had been finding compensations in deprivation and martyrdom. Her dissatisfactions were deeply rooted and her unhappiness was affecting the home situation.

In the helping process the woman was able to gain insight and find release from tensions built up over a period of years. She was able to appreciate causative factors influencing her son's behavior. The father was able to make a better work adjustment. As the home situation improved, the boy's behavior problems no longer presented serious implications.

on 8-15-40 the client telephoned the former worker requesting an appointment. The worker scheduled the appointment on the day that she was on duty at the application desk.

8-19-40 $\mathrm{Mr}$. and Mrs. R. came to the office at the appointed time. Mrs. R. assumed responsibility for opening the interview and said that so much had happened since she had last talked with us that she hardly knew where to begin. Both she and $\mathrm{Mr}$. R. had hoped that they would be able to go on without having to ask for further service. They were now in a position of not knowing what to do, so they had decided to come and talk it over with us.

Mrs. R., physically, looked much better than when we had last seen her. She had gained weight. We observed that irs. R. had much more control over herself and she did not cry throughout the interview, although her eyes 
occasionally filled with tears. We noticed little change in Mr. R. He appeared to be the same rather stolid easygoing person. Although, as indicated above, he did not at first participate in the interview, he later assumed his share of the discussion, as we would direct remarks to him and make some effort to have him take part". ..

" - In trying to bring together the various things the $\dot{R}^{\prime}$ s had told us, we asked what their plan was and what should be the next step. They wanted to get back to housekeeping as soon as possible. Mrs. R's sister is expecting to move and will be unable to continue to store their furniture. (The $R^{\prime} S$ had moved to the country where they thought the son would get along better. Mr. R's work dwindled and when $\mathrm{Mr}$. R's mother became ill the family moved in with her and a.brother and sister-in-law of Mr. R's to help care for the mother and to economize on their own living arrangements. The boy's delinquency reappeared and he was being held on a minor robbery charge. Mr. $R$. had the promise of a job and was to receive Unemployment Compensation Benefits within a week.) The fifteen year old girl who was now stajing with her aunt could not go with her if she moves. The girl says she will not come to where the $R^{\prime}$ 's are now staying because of the confusion and lack of privacy". - . Then the $R^{\prime}$ s repeated how they felt that the recent living arrangements had affected their son's behavior and their feeling that if there is any chance of his being paroled they want to be living where they san have some privacy for the boy. The $R^{\prime} s$ could remain where they were for another week. The worker suggested that the $R^{\prime} S$ look for a place to move and that they return to the office at a specific time a week later. Then they would know the outcome of the son's trial, Mr. R. Would receive his first Unemployment Compensation Benefit check or would know about his job and they would have found a place to move. Definite plans to go back to housekeeping could be made.

"As the R's were leaving, Mrs. R. said she had tried to be braver about this trouble than she had been when she last came to us. Work had been heavy in her mother-in-law's home. She had been cooking for eight to ten people a meal. Then, with all the worry about her son and $\mathrm{kr}$. R's not having work and about their family being separated, urs. $R$. had felt herself 'slipping'. She hopes, though, to be able to do something about the trouble now. She realizes, perhaps, she and $\mathrm{Mr}$. $R$. had made a mistake not coming for help sooner, but they are so anxious to be independent".

The second case illustration was really a continuation of the former contact and seemed to be accepted by the 
client and the worker as such. There was evident, however, a fresh quality to the client-worker relationship in terms of a comparative approach to former contact. The process was partially one of evaluation of the emotional growth of the client. It was almost as if the clients were using this application as a test of strength and ability to remain independent. They needed reassurance and a sense of backing by the agency. The worker did not attempt to take responsibility from the clients. In coming to the former worker $\mathrm{Mr}$. and $\mathrm{Mrs}$. R. felt no need to take blame for their son's behavior or to absolve themselves from blame. They felt that the worker knew what had happened in previous contact and accepted them without their needing to explain their part in the previous trouble.

These two cases indicate some of the value of the use of a family's previous contact with the agency. In some instances it would seem valuable for the former worker to see the client who reapplies, where there might be treatment value in the conscious measure of emotional growth and intangible reactions difficult to get into a recorded interview. (The very real,practical limitations of time and turnover in staff are recognized here.) There seems to be some threat to a client, who has experienced previous case work help through the agency, being treated as a new applicant unless the previous experience may have been too painful. The last specific reason for acceptance to be isolated here is that group of cases (already considered ear- 
Iier in this study) which were accepted for "clarification", "exploration", "further study", "investigation", or "evaluation of treatment possibilities". 


\section{Client - Worker Relationship}

As the developing intake policies and processes have been traced in the Family Service Organization, the trend has been evident of a shift from emphasis on actual content of the application interview in terms of the amount of information that could be obtained, to an emphasis on the

dynamics involved, attempting to relate
the material to them, with concentration
on diagnostic thinking from the begin-
ning, with a central focus upon the con-
stant evaluation and clarification of
the client's needs, always in terms of
agency function. Intrinsic in this pro-
cess is the establishment of the kind
of relationship needed if future con-
tacts are indicated.

In previous discussion of needs presented and services offered, it has been indicated that content of the interview repeats itself. As the intake worker has leaned less on the need for relief to insure a client's return, she has developed skills in areas of learning to meet the client's need in other areas and to help the client express this need. The intuitive interviewer, says Gordon Hamilton in The Theory and Practice of Social Case Work, recognizes attitudes in terms of insecurity, anxiety, and finds ways of putting the client at ease, in reducing fear, and in restoring damaged self esteem by giving the client individual attention, privacy, help in discussing problems of of Supervision," The Family, Jan. 1940, v. XX, no. 9, p. 289. 
interest to him, his situation, and his need. Increasingly the Family Service Organization interviews have embodied a like philosophy of giving the client the opportunity to tell his story, to say whether he wants what the agency has to offer and of the worker giving the client some idea of the agency's probable role in helping him. With this stress on the client's right to self determination and the value of mutual client - worker participation, what techniques have been used at the Family Service Organization intake desk in these respects? How has the client been stimulated to focus his problem? Has the worker been able to help the client see the real need for help beneath the verbalized request? Several case illustrations are used as basis of discussion of these questions raised.

1) 4-20-39 "Mrs. P. in district office. She is a pale woman, plain in appearance, but neatly dressed. She appears to be older than forty-nine. As we had very little identifying information we opened the interview by suggesting that Mrs. P. tell us a little more about her family. There was just she and her husband. They had no children. They lived on the second floor, subrenting from an elderly woman who depended on a daughter working four days a week at a tobacco factory. The Pis paid fifteen dollars a month rent. It had been due on April 1st, and was already twenty dollars in arrears."

" . . She didn't see how they could manage, without some help. When we asked how much $\mathbb{H r}$. P. received a week, she replied ten dollars. We suggested that we itemize expenses to see what their obligations were. They were listed as follows: rent, fifteen dollars a month or three dollars and a half a week; gas bill about fifty cents a week; milk, eighty-four cents a week (the P.'s had done this as they felt that if they had milk they would be sure to have some nourishing food); insurance, four dollars and twenty cents a month(or an average of one dollar and five cents 
a week); food two dollars a week; and medecine about one dollar a week. urs. P. is not in good health. She is under the care of a doctor who says she has low blood pressure. She also has spells with her heart and is always cold. The doctor says she needs rest.

We asked about debts.". . (one dollar and a quarter a week payment) . . These expenses totalled about ten dollars and fourteen cents which would just about equal the P's income. Mrs. P. seemed somewhat confused when we put down these figures and we asked her where she felt the trouble might be. After $\mathrm{H} r$. P. had been making about twenty dollars a week for quite awhile, did she find it hard to make the change to managing on ten? (They had had some money saved up. It was gone now and they had only the ten dollars.) Mrs. P. again looked at the figures and asked directly, 'Could you help me budget? I know something is wrong and I need help. I didn't know quite how to ask or just what I needed in the way of help. I just knew things weren't right.' We said we would be glad to help her work out some budget plans. This was one of the services we could offer. Mrs. P. then asked questions about buying food. She would like to talk with us about these things. She was so worried about managing that the whole thing had looked rather hopeless to her. We seid sometimes someone not so close to the immediate situation could help see other ways of doing things. She wondered if we could help Mr. P. get work. We said we seldom had calls. Did she feel Mir. P. might have a chance to get work again at his last place of employment? If she thought it might help we would be glad to talk with the employer. Mrs. P. would like for us to do this. Perhaps we might leave some 'clues' about Mr. P. getting work. Mrs. P. woyld also,like to get work later. Right now she isn't able. We said maybe if she could feel a little easier about things at home she would feel hetter. Mrs. P. knew that worry had a lot to do with her illness. She suggested that we talk with her doctor about her working.

Mrs. P. asked if we could come to talk to her one day next week and we made plans to visit the following Tuesday. Mr. P. had received his check yesterday. Mrs. P. planned to make a list of expenses for the week and we could use this as a basis for making plans. Mrs. P. would like to make some arrangements to pay a little on the back rent as this seemed to her to be the thing most concerning her now in the way of debts. She asked that we see the landlady, but when we suggested that it would be best for her to do this she seemed to undertsand that we would not be taking over responsibility but would be helping her to meet her own responsibilities. 
Mrs. P. thanked us for helping her to 'take a load off her mind'. She would be looking for us Tuesday morning."

The client in this interview comes to the agency with a specific relief request. She states her request with some anxiety. In securing some factual information in order to have some indication as to what the reality situation is, the caseworker senses that the client's anxiety seems to be out of proportion to the facts as presented by the client. By suggesting that the worker and the client together go over expenses, the worker secures a picture of the client's planning ability and the client is helped to face the situation. At first her reaction is one of confusion, but as the worker offers assurance and understanding and gives some suggestions as to what might be causing the difficulty, the client is able to ask specifically, "Could you help me budget? I know something is wrong and I need help". The client was focusing her probIem and at the same time had a new awareness of where to begin to do something about her trouble. The client had an initial experience in treatment which made it possible for her to relate herself positively to the agency and prepared her for the treatment to follow. Mere telling her that she did not need financial help would have had little meaning for her.

The client and the worker plan the next contact, 
each with a clear understanding of what their part in the helping process is to be. The client had a sense of doing something for herself with help from the agency, rather than the agency taking over responsibility for her.

2) 3-22-40 $\mathrm{Mr}_{\mathrm{Mr}}$. H. at the Parkland Library, having been referred from the Main Office where he had made application on 3-18-40 and an appointment given. Mr. H., a pale, anemic, ineffectual looking young man of twentythree years, said that he had stopped at the main office on his way from the iunicipal Bureau of Social Service where he had been certified for Works Progress Administration. What he wanted from the Family Service Organization was cod liver oil and orange juice for his baby who was six weeks old.

The worker asked Mr. H. several questions to help him tell about his situation. He did not seem to know how to proceed. Where was the street on which he lived? Where had he last worked? In talking with Mr. $\mathrm{H}$. he said that he had last worked as a paste boy for his father but his father now had another job. Mr. H. and his wife and baby live with $\mathrm{Mr}$. H's father-in-law. He showed some hostility to, living with his wife's family, and the worker questioned him as to his feelings. Did he find it hard to get along with his father-in-law? 'Not particularly', he answered; 'it was because he wasn't paying in his part'. 'When I work on a farm I give all I make. Me and my wife would like to be out on our own'.

The worker explained that we had asked him these questions in order to help him tell us more about himself and his family. Perhaps he wasn't quite sure about the Family Service Organization. (Worker and client discuss the Family Service Organization as not a relief agency -discuss job possibilities.)

"The worker asked $\mathrm{Mr}$. H., 'What are young people like you going to do for themselves?' He retorted, 'What are they going to do for us?'. He said, definitely, 'I would like to ask you a question: What would you do if you walked the streets from one place to the next asking for work and you couldn't get any work?'. The worker said 'I don't know'. We wondered what there was for young people who were not trained for a special trade. There were so many young men out of work, and the young men with no experience didn't have much of a chance. How far had $\mathrm{Mr}$. H. 
gone in school? He replied the sixth grade.

Perhaps the worker would help $\mathbb{M r}$. H. to think about what he would try to do for himself. It didn't seem like anyone could do anything for him. He would have to look out for himself. What would he like to do to change his situation? He said that he would like to get a job and house of their own. The worker asked, how was he going to do this? He mentioned work on a farm. He explained he occasionally did farm labor work. He liked it 'all right'. The worker said that perhaps this would be something for him. He might be able to get a farm to work on -- on a share crop basis. Maybe someday he could look forward to owning a small place of his own. He had never thought of this. He had never talked to his wife about living on a farm. You couldn't make any money on a farm. The worker said, 'No, you can't; but you can make a living'. He said maybe that was right. The worker sajd that we did not mean by talking about farming, that we thought this was the thing for him to do. He had mentioned farming, and that he likerit, so we had used this as an example of how he might try to think about ways to change his situation." ...

"The worker said that the agency wanted to help young people to try to work things out for themselves. As we had already said, it was hard to know what to do to help young people get started, but maybe $\mathbb{M r}$. H. would like to come in and talk with the worker every week or so and, together we could talk about what Mr. H. was thinking. He said he would like to come in and talk with the worker."

"Diagnostic Thinking: The worker was direct with this young boy who did not appear to have many positive qualities for treatment. With his limited education and apparently superficial work experience, he had never seemed to face the reality of having to support a family. He seemed immature and dependent, believing that 'they' would do something for him. The worker felt that the direct approach to the problem would give us some reaction on the part of $\mathrm{Mr}$. H. to determine possibilities he had for future treatment. $\mathbb{M r}$. $\mathrm{H}^{\prime} \mathrm{s}$ response seemed to indicate that he was desirous of treatment which would involve an exploratory period of seeing if talking about the difficulty of a young man finding employment would help. In the meantime service can be rendered by interpretation of the Haternal Health Clinic. Although the subject was embarrassing to $\mathbf{M} \mathbf{r}$. H., it showed him that the worker was getting down to the business of helping by suggesting ways in which the family might regulate their way of living. In addition, temporary financial assistance may be useful as a tool in treatment" ... 
In the above interview the worker was almost forcing the client into self determination and into taking responsibility. One is not certain that the client can follow through with treatment plans, but in the initial contact a thinking process was started which was apparently to the client a new approach to meeting problems -an experience in self determination. The worker in this case evidently feared subjective judgement about $\mathrm{Hr}$. H's use of help offered, and in facing the client's resistance to accepting help she depended on agency policy and definition of function. The client, seeing relief as a right, had not faced the painful problem of dependence. He protected himself from this by the assumption that the worker had no right to come between his denand and his need. The worker seemed willing to bear the feeling dependence creates and to be the one against whom the client was directing his hostility.

In summary, 1939 and 1940 have been years of change in the Family Service Organization -- changes in staff, changes in environmental conditions in approach to the client and his need. This change has involved professional growth in skills at the intake desk. The agency does not see this growth as a static attainment but as a continuing process.

For the individual, the goal of case work in these times is the develop- 
ment of a capacity to tolerate and to adjust to change. The family agency that expects to survive must continue to clarify and redefine its own job in relation to the client and to the community so that it has within itself a nucleus, however small, of what is known and stable. As we know what this nucleus is, we can describe it in simple terms to clients, other agencies, the community at large. 1

I.

Harriet Guignon, "Defining Function in Specific Cases", Defining Family Case Work Services in Relation to Client Applications, Family Welfare Association of America, $1938, \mathrm{p} .43$. 
CONCLUSION

AN EVALUATION IN PERSPECTIVE AND

INDICATIONS FOR FUTURE DEVELOPMENT 


\section{CONCLUSION}

An Evaluation in Perspective

and

\section{Indications for Future Development}

The study of the intake process and intake policies of the Family Service Organization from 1884 to 1940 has been the tracing of the gradual shift in emphasis from regarding the intake interview as a relatively simple, unimportant task handled by a clerical worker, to recognizing the intake interview as an integral part of the case work process. It is observed that from 1884 to 1940 there has been a basic change in the agency's attitude toward the client expressed in terms of an increased respect for the client as a person with the right to self determination in the client-worker relationship. There has developed a new insight and understanding of what is involved in the helping process with the resulting emphasis of planning with a client instead of for him.

As there has been an increasing emphasis on professional standards and increased training for caseworkers, there has been a new humility, an admission of limitations as well as strengths, and a trend toward refinement of skills.

The development of the intake procedure has $r \in-$ flected a gradual trend toward definition and clarifi- 
cation of agency function from a generalized to a more specific purpose.

In perspective these broad trends have emerged in viewing the work of the agency at the intake desk. As this study has centered in the analysis of the intake interview in 1939 and 1940 as a crystallization of intake techniques in light of previous development, certain more specific conclusions may be drawn from findings in this area.

Up to 1938 the intake interview centered in securing factual information from the client. There was a developing concern with individualizing the applicant but as a member of a group rather than as an individual with a specific need. 1939 may be characterized as a year of testing out of skills. One senses a groping in interpreting function and in defining methods. There was an attempt to broaden area of services. Intake interviews were characterized by exploration in all areas of the client's life. There was a definite trend toward the worker's "reading in" problems and attempt to treat problems which the client did not see.

1940 was a year of continued defining of function and of efforts toward refining skills. The client was given more opportunity to participate in the helping process. The intake worker showed a growing appreciation of the value of meeting specific needs. 
The worker's diagnostic evaluation of the intake interview was clear but there was a lack of mutual discussion between the client and the worker as to what the agency had to offer to meet the client's need and how the client and worker might mutually participate in helping the client attain certain goals. There is a need for the intake interview to end with the client and the worker seeing themselves working together on a mutually defined problem. Listing and discussion of problems outweighed services offered. Recorded diagnostic reasons for acceptance outweighed a clear understanding with the client as to reason for acceptance. It is indicated that the Family Service Organization workers at intake need to feel more confident in the area of planning in terms of setting tentative goals of treatment and making plans for some simple next steps with the client. One senses an incompleteness in many interviews in this respect. In this particular area there was an unevenness and lack of consistency of functioning at the intake desk. There seemed to be less consistent planning for the next contact in cases where the intake worker was not continuing with the case.

Although the year 1940 brought a wider variety of case acceptances, there was little protective intake where problems had not already been fairly clearly defined. 
Workers showed increasing security in certain specialized areas such as work with adolescents, budgeting service, and marriage counseling. Likewise workers showed need for further development of skills in several areas, namely work with children, with the ex-convict, and with the client who has lost a job because of his own inadequacies.

The lower income group and the economically dependent applied more frequently than the middle or higher income group. The majority of the applicants in 1939 1940 came with some expressed relief need. Other services were stressed in preference to financial help. Cases were not accepted for relief only.

Negro acceptances were extremely few in number. The function of the Family Service Organization seemed falrly clear to other agencies referring cases. There was some tendency however to refer cases in terms of the problem other than the relief need while the client being referred saw only the relief need. This raises question as to referral methods used both by other agencies and by individuals. The client should clearly understand reason for referral and be accepting and desire this service before help is effective. It was noted, particularly in relation to negro families accepted by referral in case conferences, that there was a tendency to 
lose sight of the individuality of the client and to see the referral in terms of the problem presented. Referral of cases to the Family Service Organization by other agencies and by individuals is seen as an excellent opportunity for the case by case method of elucidating function.

The number of referrals seemed comparatively small. One would anticipate an increasing consultative service and perhaps continuing clarification of the value of the several special projects such as the agreement with the Legal Aid Society, the Parkland project, etc. These and similar projects would indicate fields for demonstration jobs.

Need for careful consideration of the mechanical procedures of the intake process to insure a smoother functioning is noted. Is it not possible for the worker originally seeing the client by appointment or receiving a referral call, to complete the service and avoid the necessity of the client or the referral source seeing several workers before the case is accepted? Keeping in mind the value of the continuity of the intake and treatment processes, more careful scheduling of appointments would seem to be helpful. Would more consideration of the values of an intake process covering several interviews, lessen the number of rather vague acceptances for "study"? 
In this study one realizes that many points have been raised which indicate possibilities for further detailed study. For example, a study of the applications which come to the Family Service Organization and are not accepted by the agency as major care cases would undoubtedly reveal ways of expanding the agency's services.

In 1940 the Family Service Organization was facing declining intake and with the smaller case loads this was conducive to a more intensified job. The agency was looking to now groups to whom services might be available. A poster used for interpretive purposes stressed "the happy family" and services of a preventive nature in the areas of budgeting, marriage counseling, and work with adolescents. There has been concern about the larger social issues and world events and their effect on the agency clientele and program. The many ramifications of the defense boom psychology and implications for the present and future bring conjectures.

Viewing the developing intake philosophy and changing intake policies of the Family Service Organization one senses a flexibility and a readiness to face the new. In perspective one sees the policies and philosophy of the Family Service Organization reflected in the application interview:

it has within itself all the potentialities of what will and can hap- 
pen during future contacts. Because

of this I feel the application interview is the most vital of all our contacts with people.

I.

Else Jockel, op. cit., p. 32. 
APPENDIX 
I. Identifying Information

Date

Resident

Case Number Non-Resident

Color Religion

II. Source of Intake

A. Personal Application: Man Transient Number of children

B. Client Referred by Individual: Rela Neighbor

Other
C. Client Referred by Other Agency: Client

Woman Child Community Person

Status of Application

III. Status of $\frac{\text { Applic }}{\text { A. New }}$

B. Old (Known Previous to Present Year)

C. Recurrent (Known Previously During Current Year) Why Reopened?

IV. Family Status

A. Married Couple

B. Common Law Couple

C. Unmarried Couple

D. Unmarried Mother

E. Widow

F. Widower

G. Deserted

H. Divorced

I. Separated

J. Single Man

K. Single Woman

L. Unknown

VI. Mechanics of Intake Interview

A. Social Service Clearing: Yes

V. Financial Status Name

B. Intake Worker Contact Other Agencies Registered? Yes A. Economically independent_Income?

B. Need financial help? Supplementation Maintenance Why?

C. Intake Worker Read Previous F. S. 0. Record?

D. Client Seen by Appointment? Yes Yes___ No

C. Unknown

E. Client Seen by Whom? tinue to Carry Case?

VII. What Client Requested

What Referral Source Requested

VIII. Definition of Agency Function in Relation to Problem Presented

A. What is the Problem?

1. As Seen by Client

2. As Seen by Worker

B. Services Offered by Agency

IX. A. Reason for Acceptance

B. Possible Solution in Mind

1. As Seen by Client

2. As Seen by Worker $\left\{\begin{array}{l}\text { Recorded Diagnostically } \\ \text { Discussed with Clients }\end{array}\right.$

C. PIan for Next Contact

X. Evaluation of Worker's Activity

Evaluation of Client's Activity 


\section{Appendix II}

\section{Table I}

Intake in the Family Service Organization 1921 - 1940

Including Major and Minor Care Acceptances, White and Negro

\begin{tabular}{|l|r|r|r|r|r|r|r|r|r|}
\hline Year & 1921 & 1922 & 1923 & 1924 & 1225 & 1926 & 1927 & 1928 & 1222 \\
\hline New & 1330 & 849 & 848 & 917 & 827 & 1380 & 108 & 1122 & 1234 \\
\hline O1d & 428 & 655 & 276 & 374 & 413 & 657 & 69 & 962 & 908 \\
\hline $\begin{array}{l}\text { Recurrent* } \\
\text { Incidenta1 }\end{array}$ & - & 71 & 67 & 764 & 188 & 244 & 23 & 233 & 342 \\
\hline $\begin{array}{l}\text { Cases or } \\
\text { Minor Care } \\
\text { After_1930 }\end{array}$ & -- & 1226 & 1332 & 1545 & 1353 & & $\begin{array}{c}\text { no } \\
\text { fig- } \\
\text { ures }\end{array}$ & & \\
1151 & 1421 \\
\hline
\end{tabular}

\begin{tabular}{|c|c|c|c|c|c|c|c|c|c|c|c|}
\hline Year & 1930 & 1931 & 1932 & 1933 & 1934 & 1935 & 1236 & 1.193.7. & 1238 & 1239 & 1240 \\
\hline New & 1665 & 1873 & 1675 & 776 & 480 & 343 & 225 & 197 & 258 & 161 & 139 \\
\hline old & 652 & .716 & 1594 & 713 & 509 & 366 & 278 & 140 & 125 & -86 & 76 \\
\hline Recurrent: & $\angle 04$ & no & figur & res & 182 & 136 & 79 & 17 & 37 & 78 & 73 \\
\hline $\begin{array}{l}\text { Incidental } \\
\text { Cases or } \\
\text { Minor Care }\end{array}$ & 2898 & 2765 & $9 / 8$ & 946 & 793 & 314 & 476 & 767 & 131 & 1719 & 1205 \\
\hline
\end{tabular}

*Cases reopened during the current year 


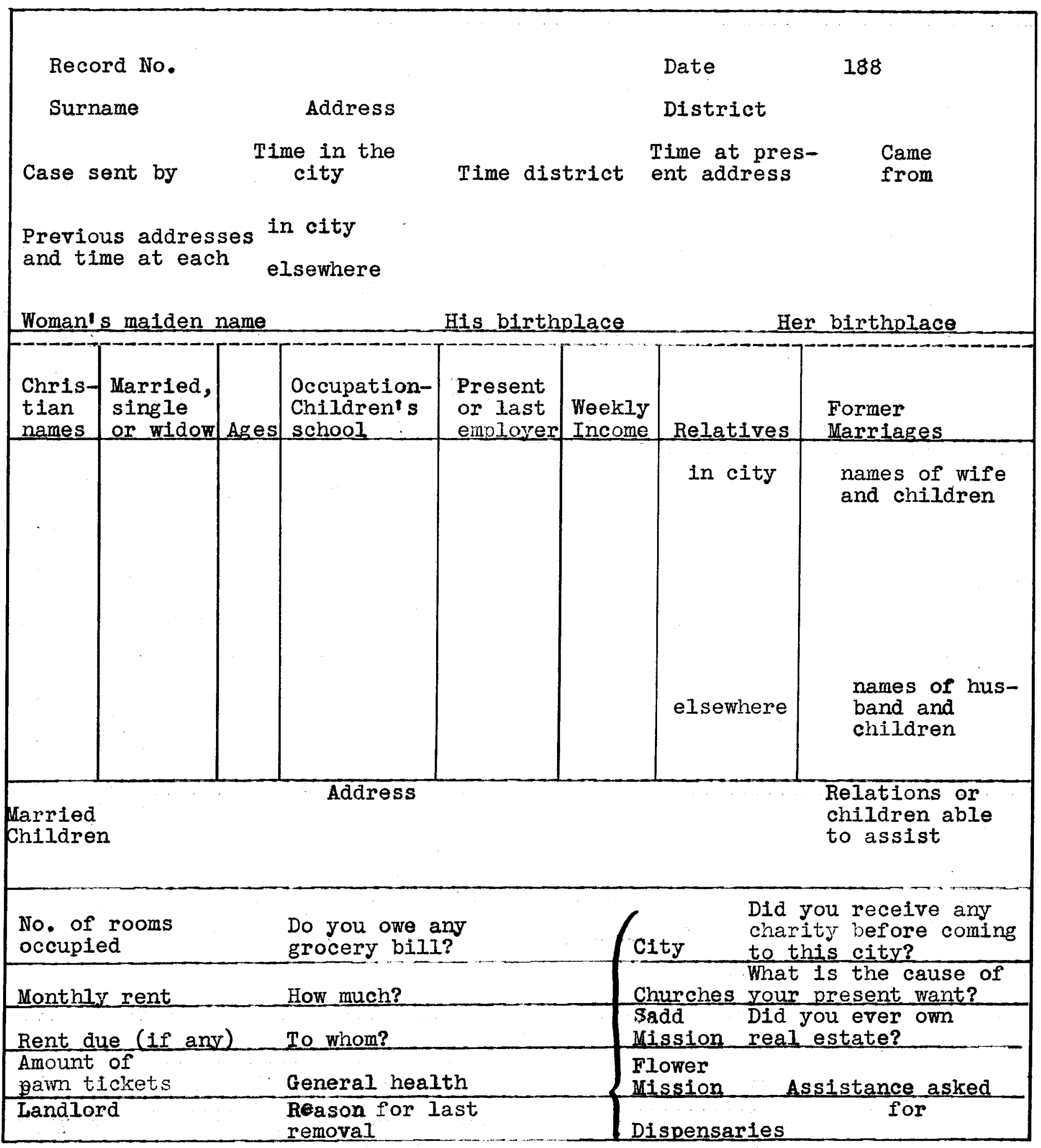




\begin{tabular}{|c|c|c|}
\hline Physician & $\begin{array}{l}\text { Do any of the } \\
\text { family drink? }\end{array}$ & $\begin{array}{l}\text { Beverolent } \\
\text { Societies. }\end{array}$ \\
\hline & What debts? & $\begin{array}{l}\text { Benevolent } \\
\text { Individuals }\end{array}$ \\
\hline & & Other Sources \\
\hline
\end{tabular}

The following should always be the order of reporting information received relative to the case from

1. personal statement

2. police

3. present and former employers

4. references

5. clergy and visitors

6. children's schoolmaster

7. other persons

8. physician

9. previous addresses

10.district agent's report

Heads of infornation dated and numbered as above
Report 
The Louisville Charity Organization Society

Report of District Committee

for month ending 188

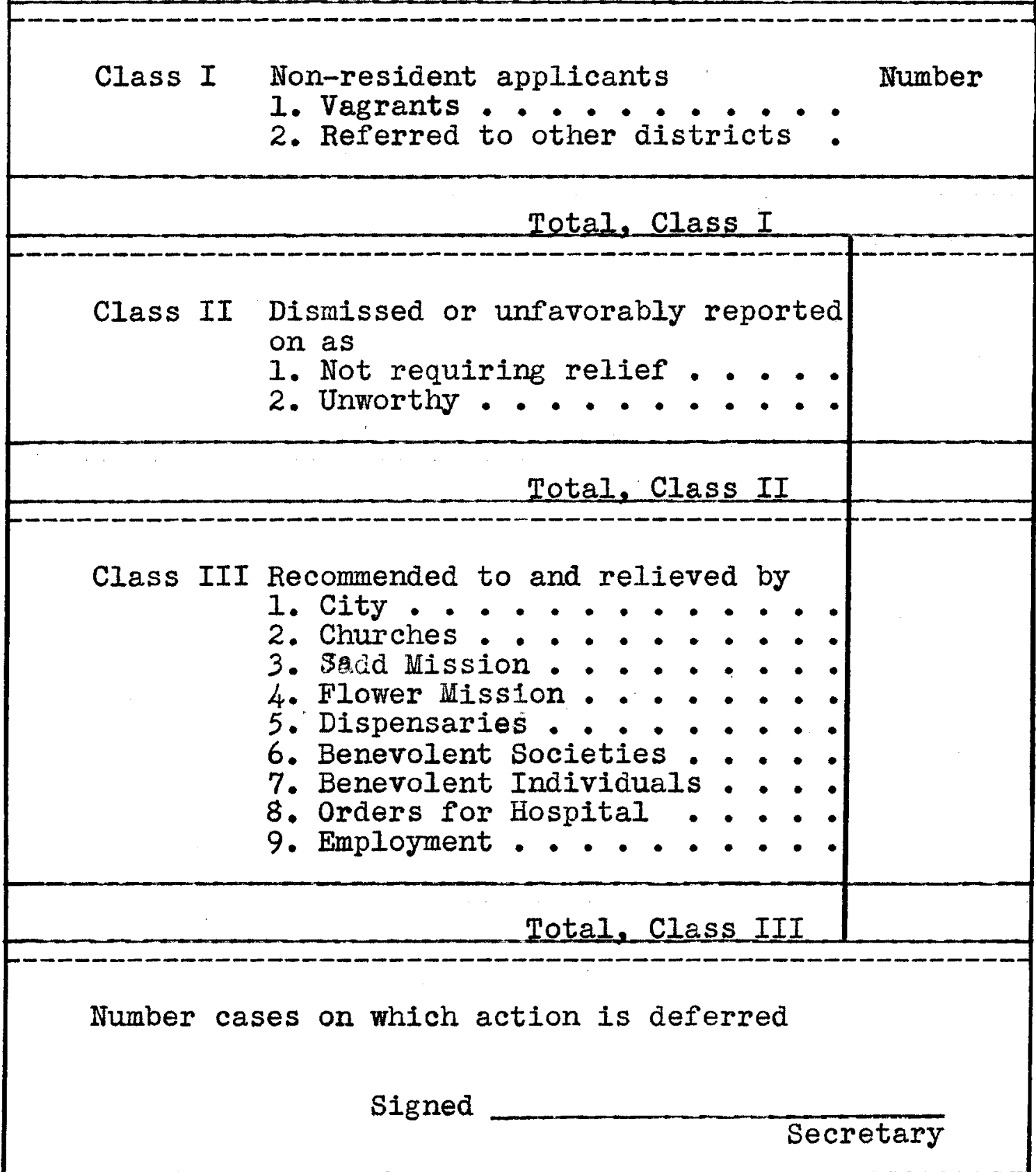




\section{Appendix V}

\section{Table III}

At Whose Request Investigation Made on New Cases -

Charity Organization Society 1891 - 1907

(No figures available 1898 through 1902)

\begin{tabular}{|c|c|c|c|c|c|c|c|c|c|c|c|c|}
\hline $\begin{array}{c}\text { Source of } \\
\text { Application }\end{array}$ & 1891 & 1892 & 1893 & 1894 & 1895 & 1896 & 1897 & 1903 & 1904 & 1905 & 1906 & 1907 \\
\hline $\begin{array}{l}\text { 1. Personal } \\
\text { Application }\end{array}$ & 22 & 52 & 74 & 271 & 85 & 40 & 43 & 10 & 17 & 11 & 4 & 12 \\
\hline 2. Waverly Hills & & & & & & & & & 2 & & & \\
\hline $\begin{array}{l}\text { 3oard of Chil- } \\
\text { dren's Guardians }\end{array}$ & & & & & & & & & 4 & 2 & 1 & 1 \\
\hline 4. Mayor of City & 155 & 208 & 303 & 285 & 84 & 67 & 77 & 17 & 14 & 3 & 10 & 12 \\
\hline 5. Police & 66 & 81 & 86 & 79 & 55 & 26 & 13 & 15 & 7 & 7 & 5 & 16 \\
\hline $\begin{array}{l}\text { 6. Private } \\
\text { Individuals }\end{array}$ & 179 & 238 & 235 & 409 & 89 & 86 & 55 & 37 & 41 & 21 & 12 & 21 \\
\hline $\begin{array}{l}\text { 7. Churches and } \\
\text { Ministers }\end{array}$ & 36 & 19 & 22 & 20 & 16 & 7 & 4 & 0 & 4 & 2 & 0 & 3 \\
\hline $\begin{array}{l}\text { 8. Young Men's Chris } \\
\text { tian Association }\end{array}$ & 10 & 10 & 12 & 14 & 1 & & & & 1 & & & \\
\hline 2. City Hospital & 13 & 6 & 3 & 9 & & & & & & & & \\
\hline $\begin{array}{l}\text { 10. Home of } \\
\text { the Friendless }\end{array}$ & 7 & 4 & & 2 & & 1 & I & 1 & & & & \\
\hline 21.Mail Line & 9 & 2 & & & 1 & & & & & & & \\
\hline
\end{tabular}


Table III, cont.

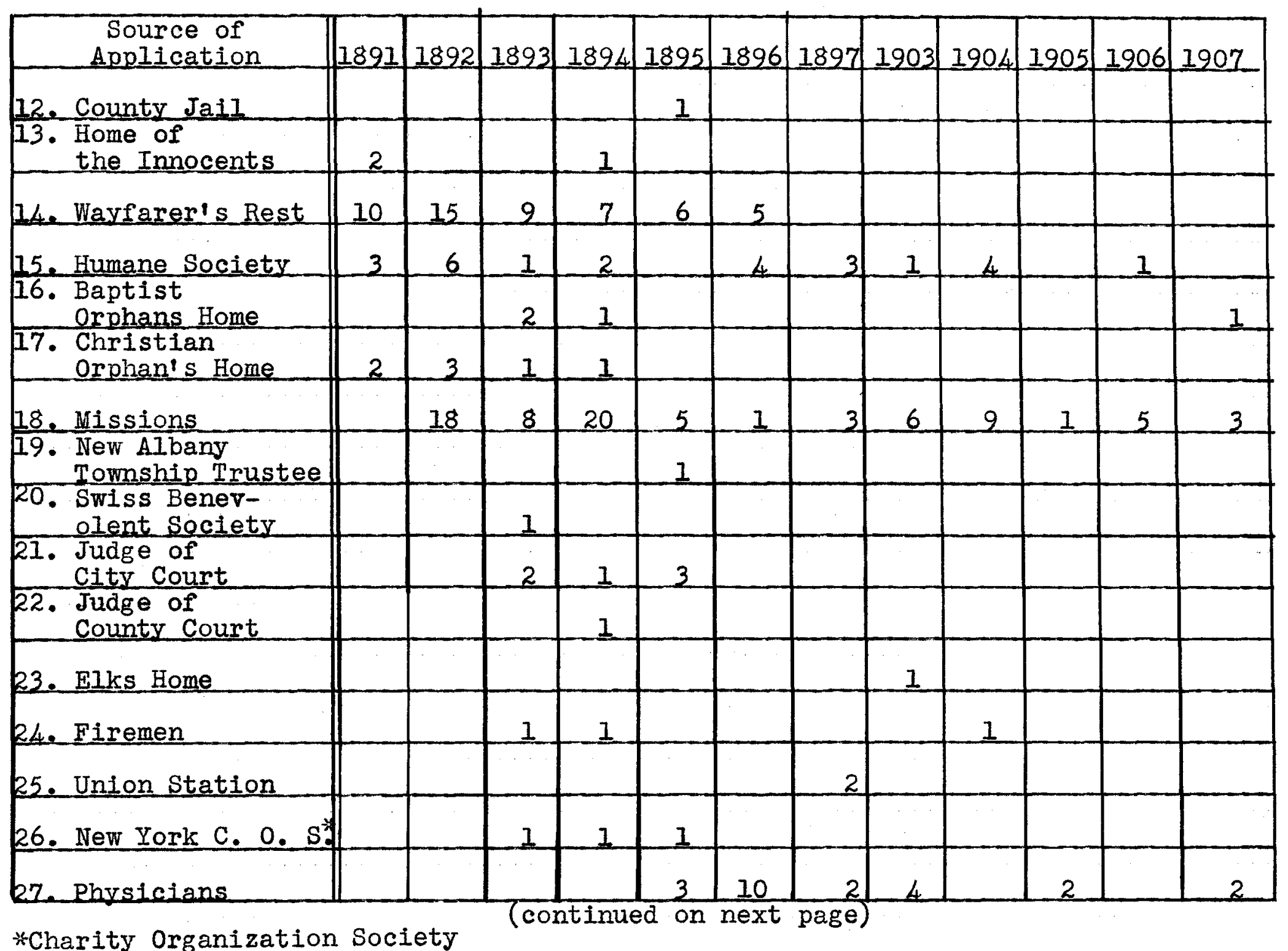


Table III, cont.

\begin{tabular}{|c|c|c|c|c|c|c|c|c|c|c|c|c|}
\hline $\begin{array}{c}\text { Source of } \\
\text { Application } \\
\end{array}$ & 1891 & 1892 & 1893 & 1894 & 1895 & 1896 & 1897 & 1903 & 1904 & 1905 & 1906 & 1907 \\
\hline $\begin{array}{l}\text { 28. Presbyterian } \\
\text { Orphanage }\end{array}$ & & & & & 1 & & & & & & & \\
\hline $\begin{array}{l}\text { 29. Young Women's } \\
\text { Boarding Home }\end{array}$ & & & & 1 & & & 1 & & & & & \\
\hline 30. District Nurse & & & & & & 1 & & & & & & \\
\hline $\begin{array}{l}\text { 31. Lou. Industrial } \\
\text { School of Reform }\end{array}$ & & & & 1 & & & 1 & & & & & \\
\hline $\begin{array}{l}\text { 32. Ky. Institute } \\
\text { for the Blind }\end{array}$ & & & & & & 1 & & & & & & \\
\hline $\begin{array}{l}\text { 33. Kentucky School } \\
\text { of Medecine }\end{array}$ & & & & 2 & & & & & & & & \\
\hline $\begin{array}{l}\text { 34. Chicago } \\
\text { Relief Society }\end{array}$ & & & & & & 3 & & & & & & \\
\hline $\begin{array}{l}\text { 35. Louisville } \\
\text { University } \\
\end{array}$ & & & & 2 & & & & & & & & \\
\hline $\begin{array}{l}\text { 36. Louisville } \\
\text { City Railway }\end{array}$ & & & & & & 1 & & & & & & \\
\hline 37. Railroad Companie & & & & 1 & 5 & 1 & & & & & 1 & \\
\hline 38. Truant officer & & & & & 1 & & & & & & & 1 \\
\hline 39. Board of Safety & & & & & & & 2 & & & & & \\
\hline $\begin{array}{l}\text { 40. St. Louis Provi- } \\
\text { dent Association }\end{array}$ & & & & & 1 & & & & & & & \\
\hline 41. Park Guard & & & & & & 1 & & & & & & \\
\hline $\begin{array}{l}\text { 42. Friends } \\
\text { Outside City }\end{array}$ & & & & & & & & & & & & 1 \\
\hline 43. Salvation Army & & & & & & & & 1 & & & & 1 \\
\hline 44. Settlement House & & & & & & & & & 1 & 1 & & 2 \\
\hline Total & 514 & 669 & 766 & 1135 & 359 & 256 & 212 & 93 & 105 & 50 & 46 & 76 \\
\hline
\end{tabular}


Appendix VI

Table IV

Decisions Made on Applications 1886 - 1888

\begin{tabular}{|c|c|c|c|c|c|c|}
\hline & & 886 & & 887 & 1 & 388 \\
\hline Classification & Total & Percent & Tota] & Percent & Total & Percent \\
\hline $\begin{array}{l}\text { Class I } \\
\text { Worthy of Continuous } \\
\text { Relief (Aged, incur- } \\
\text { able and orphans) }\end{array}$ & 39 & 3.35 & 21 & 2.73 & 7 & .80 \\
\hline $\begin{array}{l}\text { Worthy of Temporary } \\
\text { Relief (IIIness, ac- } \\
\text { cident or other tem- } \\
\text { porary trouble) }\end{array}$ & 413 & 35.55 & 298 & 38.75 & 281 & 32.18 \\
\hline $\begin{array}{l}\text { Class II } \\
\text { Weeding Work Rather } \\
\text { Than Relief (Those } \\
\text { willing to work, } \\
\text { the shiftless or in- } \\
\text { temperate not yet } \\
\text { hopelessly so) }\end{array}$ & 341 & 29.35 & 259 & 33.68 & 303 & 34.70 \\
\hline $\begin{array}{l}\text { Class III } \\
\text { Jnworthy (Those hav- } \\
\text { ing property or rel- } \\
\text { atives able to sup- } \\
\text { port, the intemper- } \\
\text { ate, vicious, per- } \\
\text { manentiy shiftless, } \\
\text { professional beggars } \\
\text { and tramos) }\end{array}$ & 369 & 31.75 & 191 & 24.84 & 235 & 26.92 \\
\hline $\begin{array}{l}\text { Not Requiring Re- } \\
\text { lief }\end{array}$ & & & & & 47 & \\
\hline Total & 1162 & 100.00 & 769 & 100.00 & 873 & 100.00 \\
\hline
\end{tabular}




\section{Appendix VI, cont.}

\section{Table V}

Decisions Made on Applications 1889 - 1907

(Figures for years 1898 - 1902 not available)

\begin{tabular}{|c|c|c|c|c|c|c|c|c|c|c|c|c|c|c|}
\hline Decision Made & $\begin{array}{l}18 \\
89 \\
\end{array}$ & 90 & 91 & .22 & 93 & 94 & 95 & 96 & 97 & $\begin{array}{l}19 \\
03 \\
\end{array}$ & 04 & 05 & 06 & 07 \\
\hline $\begin{array}{l}\text { Should Have } \\
\text { Continued Relief }\end{array}$ & 10 & 9 & 20 & 14 & y & & & & & & & & & \\
\hline $\begin{array}{l}\text { Should Have } \\
\text { Temporary Relief }\end{array}$ & 162 & 163 & 156 & 206 & 297 & 363 & 82 & 77 & 42 & 36 & 29 & 21 & 20 & 43 \\
\hline $\begin{array}{l}\text { Should Have } \\
\text { Intermittent Relief }\end{array}$ & 0 & 0 & 2 & 17 & 27 & 21 & 12 & 12 & 13 & 10 & 14 & 6 & 9 & 3 \\
\hline $\begin{array}{l}\text { Need Work } \\
\text { Rather Than Relief }\end{array}$ & 153 & 117 & 135 & 165 & 199 & 587 & 144 & 81 & 58 & 7 & 14 & 7 & 6 & 2 \\
\hline $\begin{array}{l}\text { Need Relief If } \\
\text { No Work Provided }\end{array}$ & & & & & & & & & & 6 & 7 & 2 & 4 & 5 \\
\hline $\begin{array}{l}\text { Should Have } \\
\text { Indoor Relief }\end{array}$ & 11 & 31 & 43 & 64 & 29 & 20 & 6 & 3 & 5 & 3 & 3 & 1 & 1 & \\
\hline $\begin{array}{l}\text { Transportation from } \\
\text { the City }\end{array}$ & & & 36 & 55 & 57 & 44 & 51 & 33 & 29 & 5 & 8 & -4 & 1 & 8 \\
\hline $\begin{array}{l}\text { Visitation and } \\
\text { Advice Only }\end{array}$ & & & 6 & 12 & 9 & 2 & 4 & 6 & 2 & 2 & 2 & 2 & 0 & 1 \\
\hline $\begin{array}{l}\text { Should Be Disci- } \\
\text { plined or Unworthy }\end{array}$ & 122 & 73 & 71 & 82 & 20 & 53 & 20 & 16 & 16 & 8 & 14 & 1 & 2 & \\
\hline Wot Requiring Action & 33 & 41 & 45 & 54 & 51 & 45 & 40 & 28 & 47 & 16 & 14 & .6 & 3 & 14 \\
\hline Total & 491 & 434 & 514 & 669 & 766 & 1135 & 359 & 256 & 212 & 93 & 105 & 50 & 46 & 76 \\
\hline
\end{tabular}




\section{Application Card - Associated Charities}

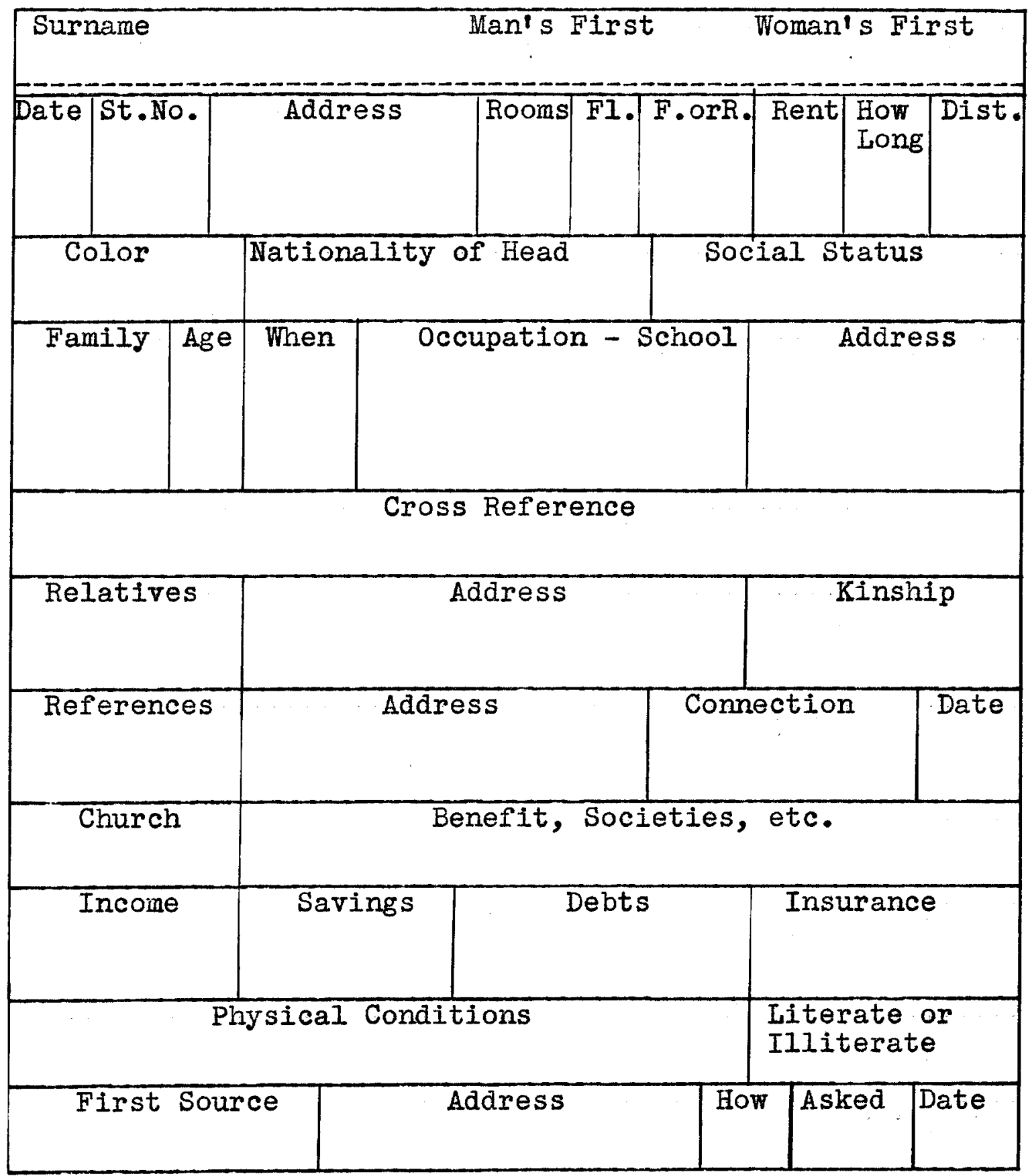




\section{Appendix VIII}

Table VI

Identifying Information on Sample of Cases Read 1907 - 1921 According to Residence, Religion, and Number of Children in the Family

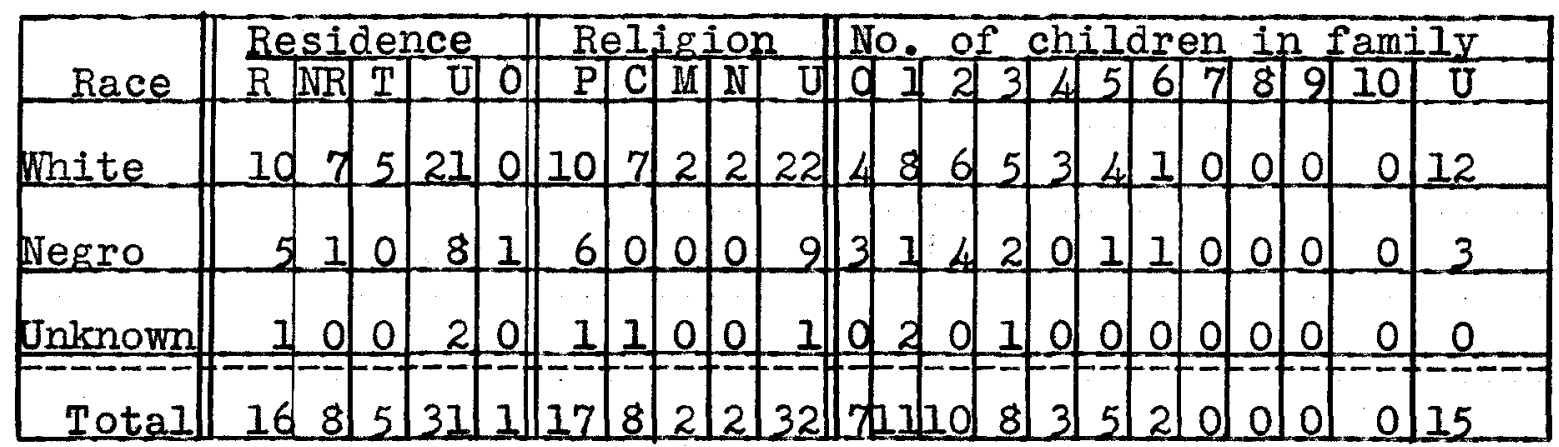

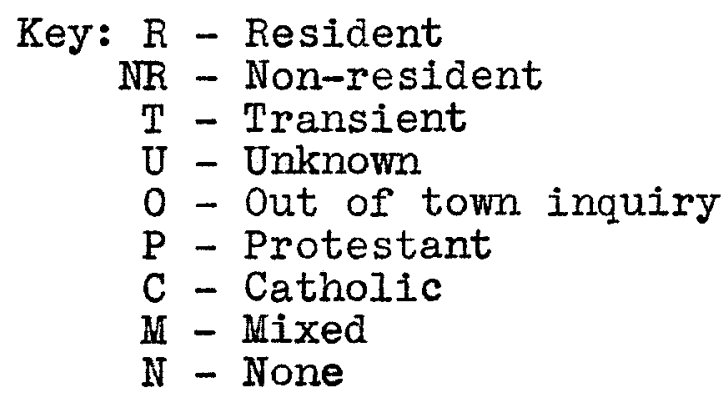

Table VII

Source of Application -

Sample of Application Interviews 1907 - 1921

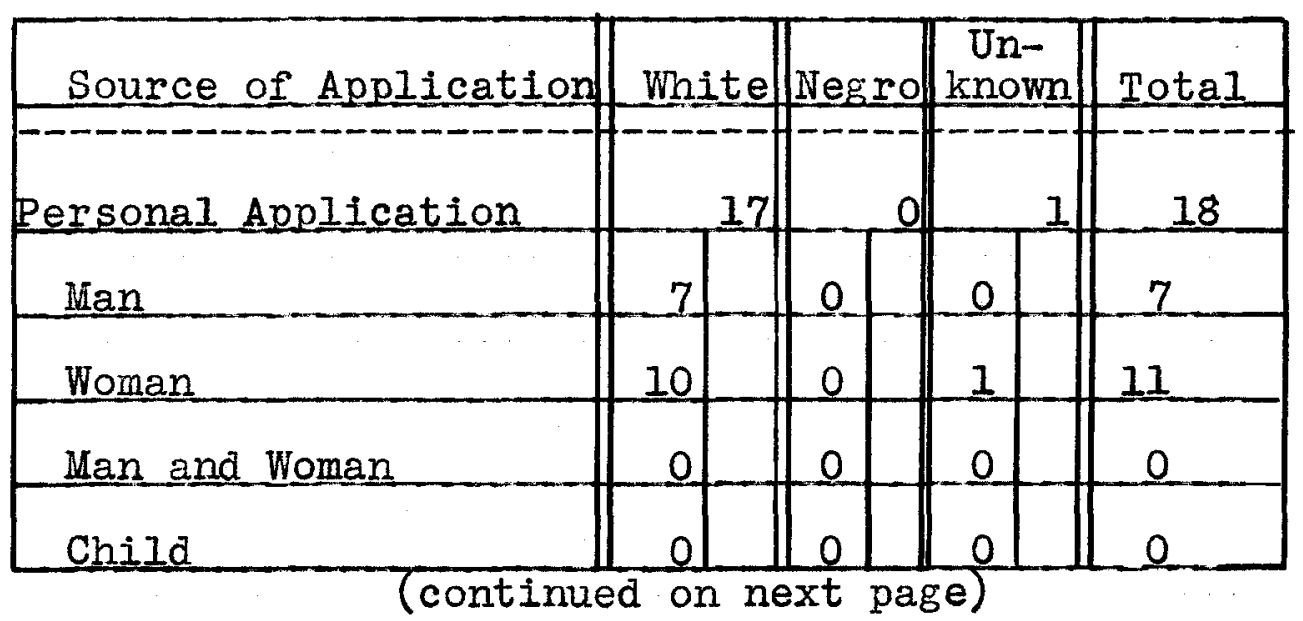


Table VII, cont.

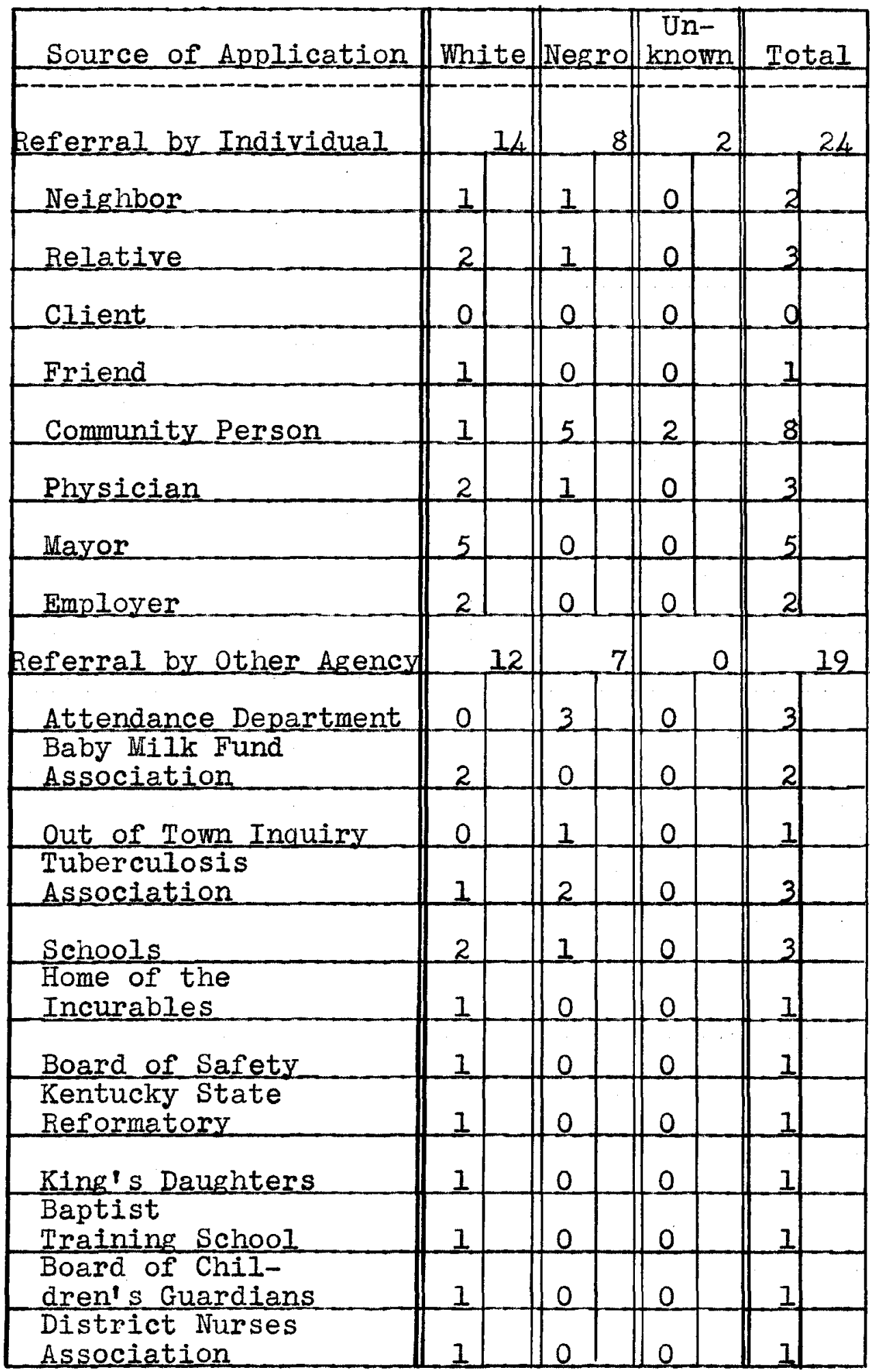




\section{Appendix IX}

\section{Table VIII}

Status of Cases 1907 - 1921 According to New, 0ld, Recurrent Application to the Associated Charities

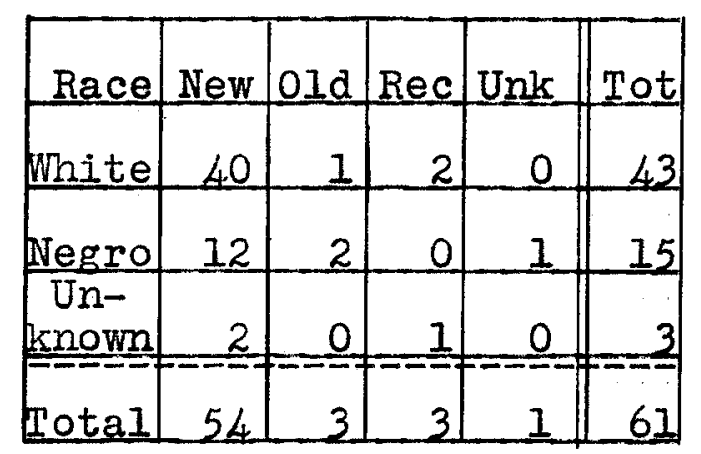

Key: Rec - Recurrent, Unk - Unknown, Tot - Total

\section{Table IX}

Family Status of Applicants 1907 - 1921

(Sample of 61 cases)

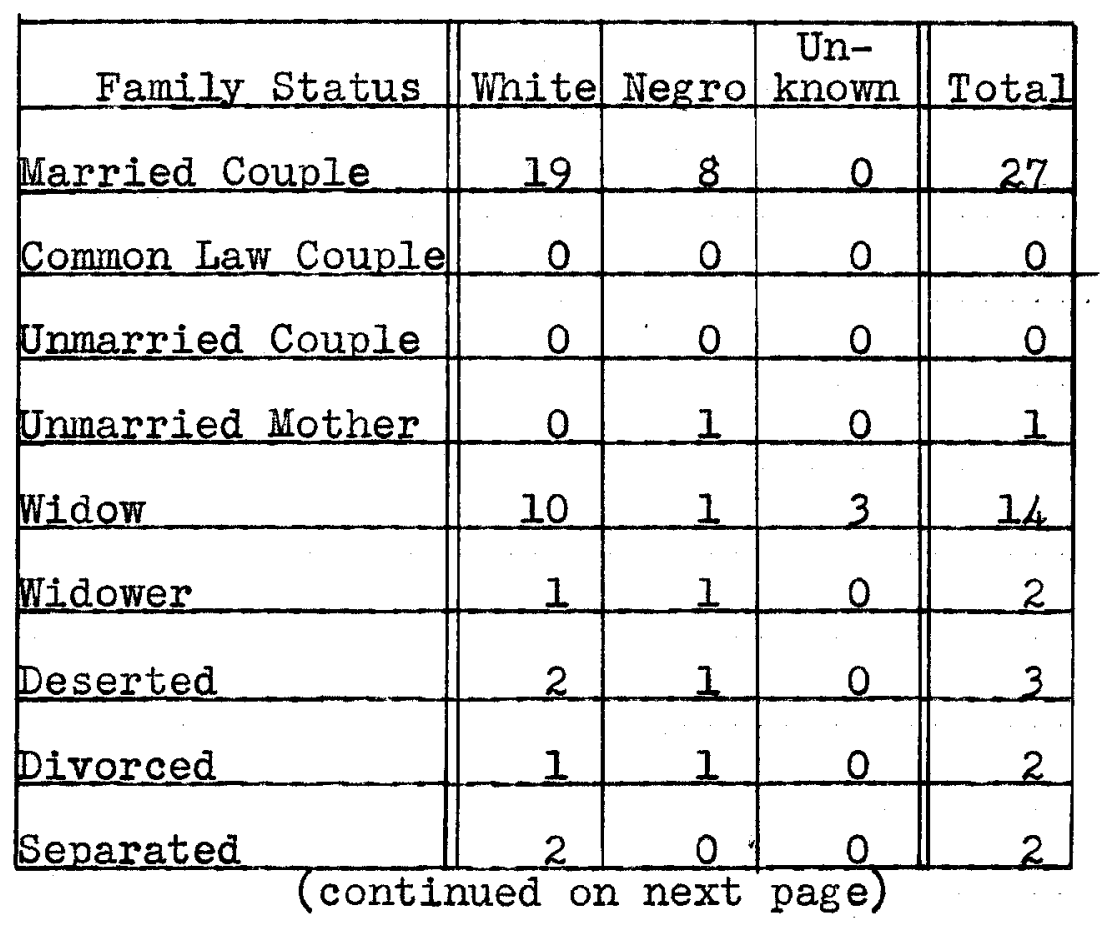


Table IX, cont.

\begin{tabular}{|c||r|r|r|r|}
\hline Family Status & White & Negro & $\begin{array}{c}\text { Un- } \\
\text { known }\end{array}$ & Total \\
\hline Single Man & 4 & 0 & 0 & 4 \\
\hline Single Woman & 2 & 1 & 0 & 3 \\
\hline Unknown & 2 & 1 & 0 & 3 \\
\hline Total & 43 & 15 & 3 & 61 \\
\hline
\end{tabular}




\section{Appendix X}

\section{Table X}

Financial Status in a Sample of Cases 1907 - 1921

\begin{tabular}{|c||c|c|c||r|}
\hline Financial Status & White & Negro & $\begin{array}{c}\text { Unown } \\
\text { known }\end{array}$ & Total \\
\hline Need Maintenance Help & 10 & 0 & 0 & 10 \\
\hline Need Supplementary Help & 3 & 2 & 0 & 5 \\
\hline EconomicalIy Independent & 1 & 2 & 0 & 3 \\
\hline Unknown & 29 & 11 & 3 & 43 \\
\hline- & 43 & 15 & 3 & 61 \\
\hline
\end{tabular}

Table XI

Mechanics of the Intake Interview in a Sample of Cases 1907 - 1921

\begin{tabular}{|c|c|c|c|c|c|c|}
\hline Mechanics of Intake & Yes & No & NPIF & $\begin{array}{l}\text { Not } \\
\text { Ind }\end{array}$ & Vis & \\
\hline $\begin{array}{l}\text { Social Service Exchange } \\
\text { clearing - "Registered" }\end{array}$ & 47 & 0 & - & 14 & - & \\
\hline $\begin{array}{l}\text { Intake Worker Consulted } \\
\text { other Agencies Registered }\end{array}$ & 2 & 1 & 3 & 55 & $=$ & \\
\hline $\begin{array}{l}\text { Intake Worker Read Previous } \\
\text { Associated Charities Record }\end{array}$ & 2 & 0 & 54 & 5 & $=$ & \\
\hline Client Was Seen by Appoint & 0 & 0 & $=$ & 18 & 43 & \\
\hline
\end{tabular}

Key: NPIR - No previous inquiry registered Not Ind - Not Indicated

Vis - Client Not Seen until visit made Tot - Total 
Appendix XI

Table XII

Staff of the Family Service Organization

1921 - 1929

\begin{tabular}{|c|c|c|c|c|c|c|c|c|c|}
\hline Position & $\begin{array}{l}19 \\
21 \\
\end{array}$ & 22 & 23 & 24 & 25 & 26 & 27 & 28 & 29 \\
\hline General Secretary & 1 & I & 1 & 1 & 1 & 1 & 1 & 1 & $I$ \\
\hline Case Supervisor & & & 1 & 1 & 1 & 1 & 1 & $I$ & 1 \\
\hline District Supervisor & & & 3 & 3 & 3 & 3 & 4 & 4 & 4 \\
\hline $\begin{array}{l}\text { Inter-city and Forward- } \\
\text { ing Center Worker }\end{array}$ & & & 1 & 1 & 1 & 1 & 1 & 1 & 1 \\
\hline Application Worker & & & 1 & 1 & 1 & 1 & 1 & 1 & 1 \\
\hline Home Economist & 1 & $\stackrel{0}{-1}$ & 1 & 1 & & & & & \\
\hline Child Placing Visitor & & 疍 & 1 & & & & & & \\
\hline Employment Director & & $\stackrel{\infty}{\infty}$ & & & & & & & 1 \\
\hline Night Clerk & & $\stackrel{0}{q}$ & 1 & 1 & 1 & 1 & 1 & 1 & 1 \\
\hline Visitors & 9 & 承 & 16 & 16 & 17 & 17 & 18 & 18 & 20 \\
\hline Bookkeepers & & 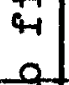 & 1 & 1 & 1 & 2 & 2 & 2 & 2 \\
\hline $\begin{array}{l}\text { Stenographers and } \\
\text { Filing Clerks }\end{array}$ & & दे & 6 & 7 & 8 & 7 & 7 & 8 & 8 \\
\hline Total & & & 33 & & 34 & & & 37 & \\
\hline
\end{tabular}




\section{Appendix XII}

"Blue Slip" - Application Form

Used by the Family Service Organization to 1930

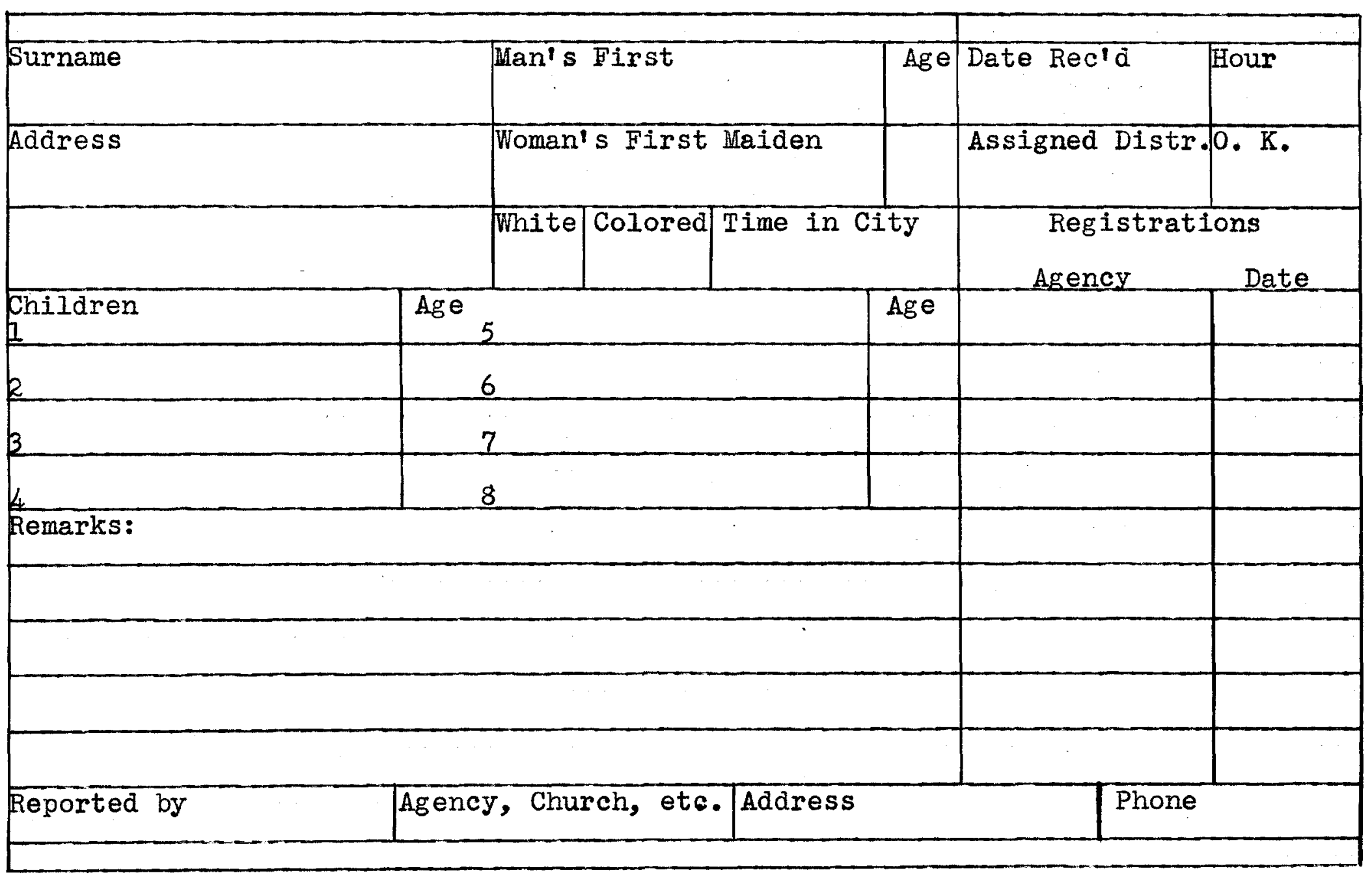




\section{Appendix XIII}

Table XIII

Identifying Information of Sample of Cases Read 1921 - 1929
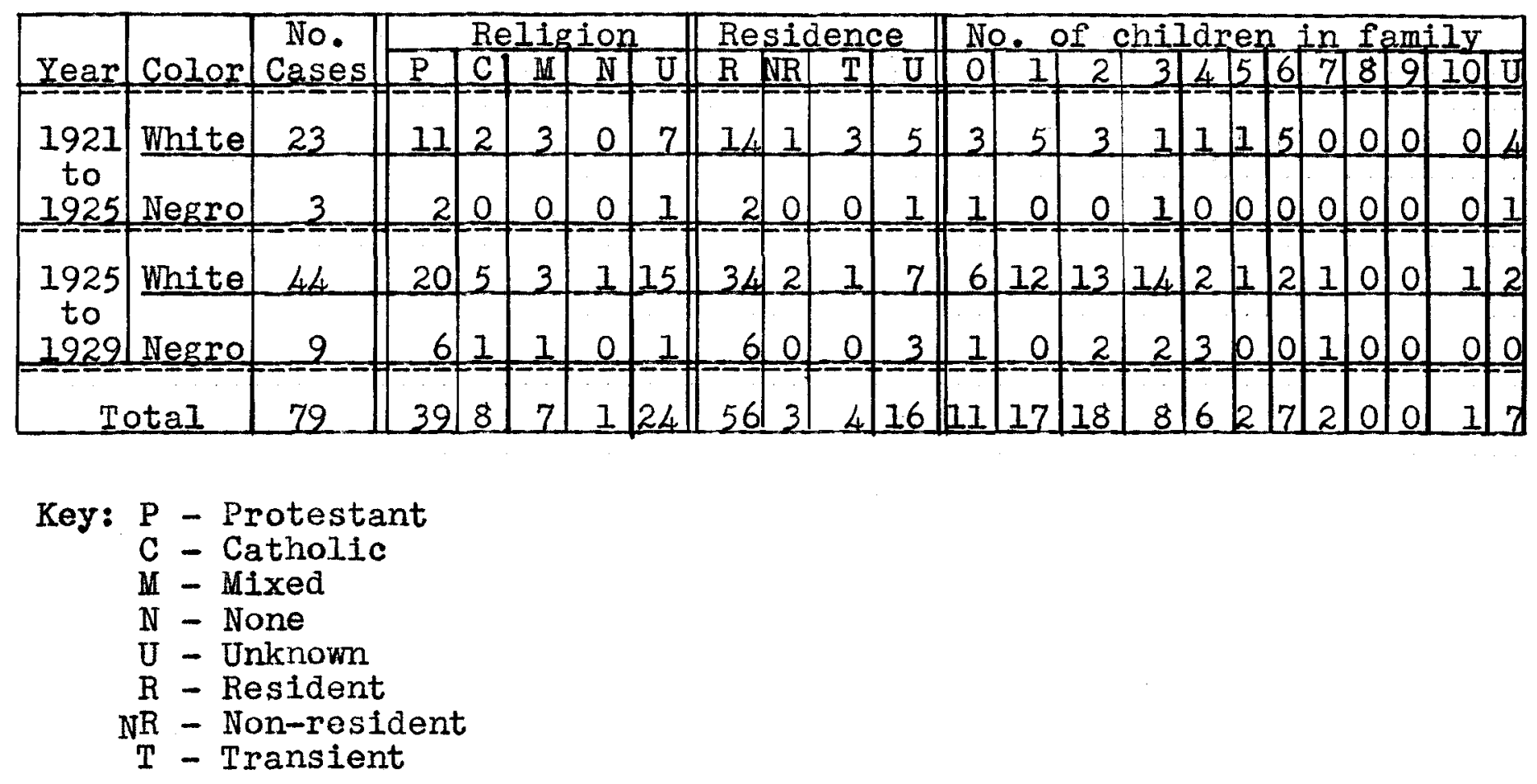
Appendix XIV

\section{Table XIV}

Source of Application of 79 Cases 1921 - 1929

A. Personal Application

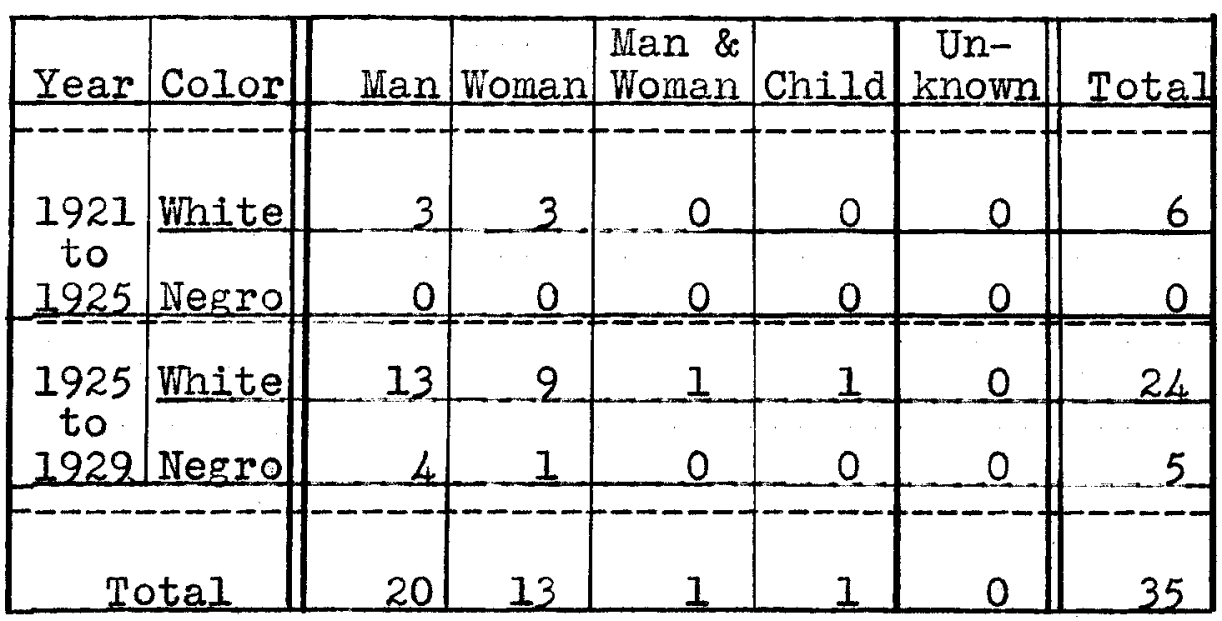

B. Referrals by Individuals

\begin{tabular}{|c|c|c|c|c|c|}
\hline $\begin{array}{l}\text { Individual } \\
\text { Referring Case }\end{array}$ & $\frac{192}{\text { White }}$ & $\frac{1-25}{\text { Tivegro }}$ & White & N-29 & Total \\
\hline Neighbor & 2 & 0 & 1 & 0 & 3 \\
\hline Relative & 2 & 0 & 2 & 0 & 4 \\
\hline Community Person & 4 & 0 & 3 & 1 & 8 \\
\hline Employer & 1 & 1 & 0 & 2 & 4 \\
\hline Minister & 1 & 0 & 0 & 0 & 1 \\
\hline School Principal & 1 & 0 & 0 & 0 & 1 \\
\hline School Nurse & 1 & 0 & 0 & 0 & 1 \\
\hline Other FSO Client* & 0 & 0 & 1 & 0 & 1 \\
\hline Attorney & 0 & 0 & 1 & 0 & 1 \\
\hline Physician & 0 & 0 & $I$ & 0 & 1 \\
\hline
\end{tabular}


Table XIV, B, cont.

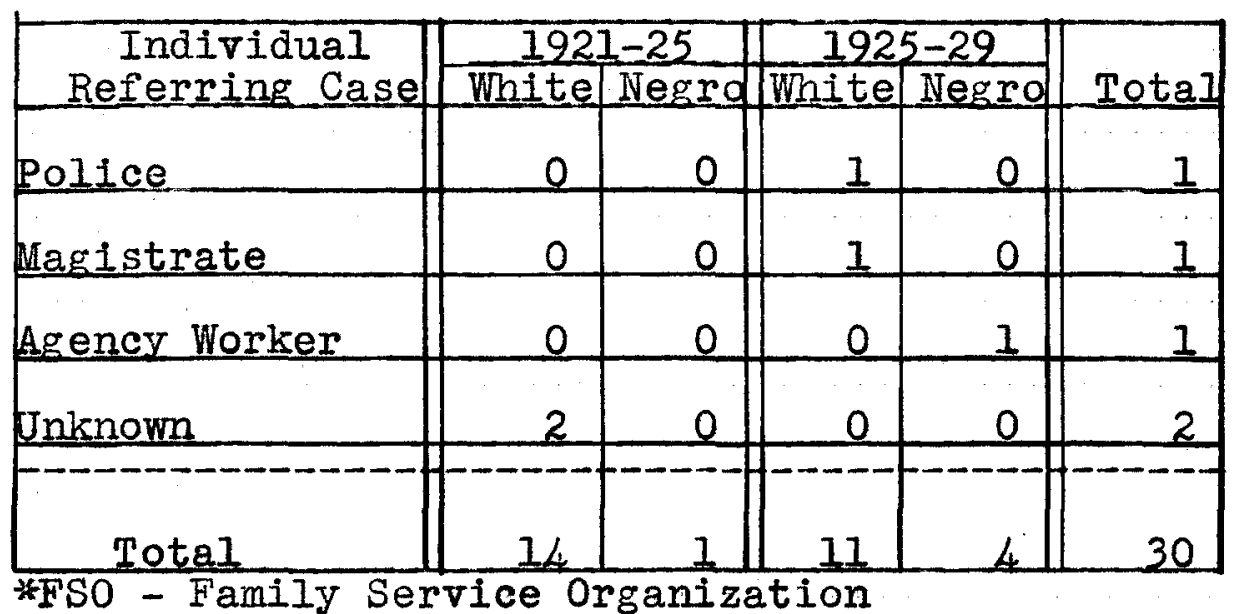

C. Referrals by Other Agencies

\begin{tabular}{|c|c|c|c|c|c|}
\hline $\begin{array}{c}\text { Agency } \\
\text { Referring Case }\end{array}$ & White & -25 & White & $\frac{-29}{\text { Negro }}$ & Total \\
\hline Attendance & & & & & \\
\hline Department & 2 & 1 & 0 & 0 & 3 \\
\hline $\begin{array}{l}\text { Dut of Town } \\
\text { Inquiry }\end{array}$ & 1 & 1 & 1 & 0 & 3 \\
\hline Community Chest & 0 & 0 & 1 & 0 & 1 \\
\hline $\begin{array}{l}\text { Louisville and } \\
\text { Jefferson County } \\
\text { Children's Home }\end{array}$ & 0 & 0 & 1 & 0 & 1 \\
\hline Waverly Hills & 0 & 0 & 1 & 0 & 1 \\
\hline Children's Bureau & 0 & 0 & 1 & 0 & 1 \\
\hline Kings Daughters & $\underline{0}$ & 0 & 1 & 0 & 1 \\
\hline Community House & 0 & 0 & 1 & 0 & 1 \\
\hline $\begin{array}{l}\text { Travelers } \\
\text { Aid Society }\end{array}$ & 0 & 0 & 1 & 0 & 1 \\
\hline $\begin{array}{l}\text { Tuberculosis } \\
\text { Clinic }\end{array}$ & 0 & 0 & 1 & 0 & 1 \\
\hline Total & 3 & 2 & 9 & 0 & 14 \\
\hline
\end{tabular}




\section{Appendix XV}

\section{Table XV}

Status of Application 1921 - 1929

\begin{tabular}{|c|c|c|c|c|c|c|}
\hline Kear & Color & New & 01d & $\begin{array}{l}\text { Recur } \\
\text { rent }\end{array}$ & $\begin{array}{l}\text { Un- } \\
\text { snown }\end{array}$ & Total \\
\hline 1921 & White & 18 & 4 & 1 & 0 & 23 \\
\hline 7925 & Negro & 2 & 0 & 0 & 1 & 3 \\
\hline 1925 & White & 25 & 16 & 3 & 0 & 44 \\
\hline $\begin{array}{l}\text { to } \\
1929\end{array}$ & Negro & 7 & 2 & 0 & 0 & 9 \\
\hline \multicolumn{2}{|c|}{ Total } & 52 & 22 & 4 & 1 & 79 \\
\hline
\end{tabular}

Table XVI

Family Status of Applicants 1921 - 1929

\begin{tabular}{|c|c|c|c|c|c|}
\hline & 192 & -25 & 192 & -29 & \\
\hline Family Status & White & Negro & White & Negro & Total \\
\hline Married Couple & 15 & 2 & 29 & 4 & 50 \\
\hline Common Law Couple & 0 & 0 & 0 & 0 & 0 \\
\hline Unmarried Couple & 0 & 0 & 0 & 0 & 0 \\
\hline Unmarried Mother & 0 & 0 & 1 & 0 & 1 \\
\hline Widow & 2 & 0 & 0 & 2 & 4 \\
\hline Widower & 0 & 0 & 3 & 0 & 3 \\
\hline Deserted & 1 & 0 & 4 & 1 & 6 \\
\hline Divorced & 0 & 0 & 2 & 1 & 3 \\
\hline Separated & 3 & 0 & 2 & 0 & 5 \\
\hline Single Man & 1 & 0 & 0 & 0 & 1 \\
\hline Single Woman & 1 & 0 & 0 & 0 & 1 \\
\hline Unknown & 0 & 1 & 3 & 1 & 5 \\
\hline Total & 23 & 3 & 44 & 9 & 79 \\
\hline
\end{tabular}


Table XVII

Statistics of Financial Status

of Sample of Cases Read 1921 - 1929

A. Financial Status

\begin{tabular}{|c|c|c|c|c|c|}
\hline \multirow[b]{2}{*}{ Financial Status } & \multicolumn{2}{|c|}{$1921-25$} & \multicolumn{2}{|c|}{$1925-29$} & \multirow[b]{2}{*}{ Total } \\
\hline & White & Negro & White & Negro & \\
\hline Economically & & & & & \\
\hline Independent & 3 & 0 & 4 & 0 & 7 \\
\hline Need Supplemen- & 4 & 0 & 7 & 2 & 13 \\
\hline Need Mainte- & 6 & 0 & 27 & 5 & 38 \\
\hline Unknown & 10 & 3 & 6 & 2 & 21 \\
\hline Total & 23 & 3 & 44 & 9 & 79 \\
\hline
\end{tabular}

B. Income of the Economically Independent Applicant

\begin{tabular}{|c|c|c|c|c|c|}
\hline Weekly & 1923 & -25 & 192 & -29 & \\
\hline Income & & & & Negro & Total \\
\hline$\$ 20$ & 1 & & & & 1 \\
\hline $30=40$ & 1 & & 1 & & 2 \\
\hline 43 & & & 1 & & 1 \\
\hline $\begin{array}{l}\text { Relatives } \\
\text { Supporting }\end{array}$ & & & 2 & & 2 \\
\hline Unknown & 1 & & & & 1. \\
\hline Total & 3 & 0 & 4 & 0 & 7 \\
\hline
\end{tabular}


Table XVII, cont.

C. Income of Applicants Requesting Supplementary Help

\begin{tabular}{|l|c|c|c|c||c|}
\hline Weekly & \multicolumn{2}{|c|}{$1921-25$} & $1925-29$ & Total \\
\cline { 2 - 6 } Income & White & Negro & White & Negro & Tot \\
\hline 2.00 & & & 1 & & 1 \\
\hline 5.00 & 1 & & & & 1 \\
\hline 9.00 & 1 & & & 1 & 2 \\
\hline 12.00 & 1 & & & & 1 \\
\hline 1.75 day & & & 1 & & 1 \\
\hline Jnknown & 1 & & 4 & 1 & 6 \\
\hline Total & 4 & 0 & 7 & 2 & 13 \\
\hline
\end{tabular}

D. Why Need Supplementary Financial Assistance

\begin{tabular}{|c|c|c|c|c|c|}
\hline Cause of Need & $\frac{192}{\text { White }}$ & $=-25$ & $\frac{192}{\text { White }}$ & $\frac{5-29}{\text { Negro }}$ & Total \\
\hline $\begin{array}{l}\text { Relatives Unable to } \\
\text { Assume Entire Support }\end{array}$ & $+2=0$ & a & 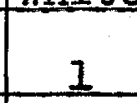 & $n_{0}+\mathrm{c}$ & 1 \\
\hline Partial Employment & 0 & 0 & 1 & 0 & 1 \\
\hline Help in Moving & 0 & 0 & 1 & 0 & 1 \\
\hline Illness & 1 & 0 & 0 & 0 & \\
\hline Insufficient Income & 1 & 0 & 4 & 2 & 7 \\
\hline Clothing Need & 1 & 0 & 0 & 0 & 1 \\
\hline Need Screens & 1 & 0 & $\underline{0}$ & 0 & 1 \\
\hline Total & 4 & 0 & 7 & 2 & 13 \\
\hline
\end{tabular}


Table XVII, cont.

E. Why Need Maintenance Relief

\begin{tabular}{|c|c|c|c|c|c|}
\hline \multirow[b]{2}{*}{ Cause of Need } & \multirow{2}{*}{\multicolumn{2}{|c|}{$1921-25$}} & \multicolumn{2}{|c|}{$1925-29$} & \multirow[b]{2}{*}{ Total } \\
\hline & & Negro & White & Negro & \\
\hline $\begin{array}{l}\text { Physically } \\
\text { Incapacitated }\end{array}$ & 0 & 0 & 2 & 1 & +0 \\
\hline IIIness & 2 & 0 & 5 & 2 & 9 \\
\hline $\begin{array}{l}\text { Man } \\
\text { out of Town }\end{array}$ & 0 & $\underline{0}$ & 1 & 0 & 1 \\
\hline Unemployment & 3 & 0 & 11 & 2 & 16 \\
\hline Tuberculosis & 0 & 0 & 1 & 0 & $I$ \\
\hline Desertion & 1 & 0 & 3 & 0 & 4 \\
\hline Unknown & 0 & 0 & 4 & 0 & 4 \\
\hline Total & 6 & 0 & 27 & 5 & 38 \\
\hline
\end{tabular}


Table XVIII

Mechanics of the Intake Interview 1921 - 1929

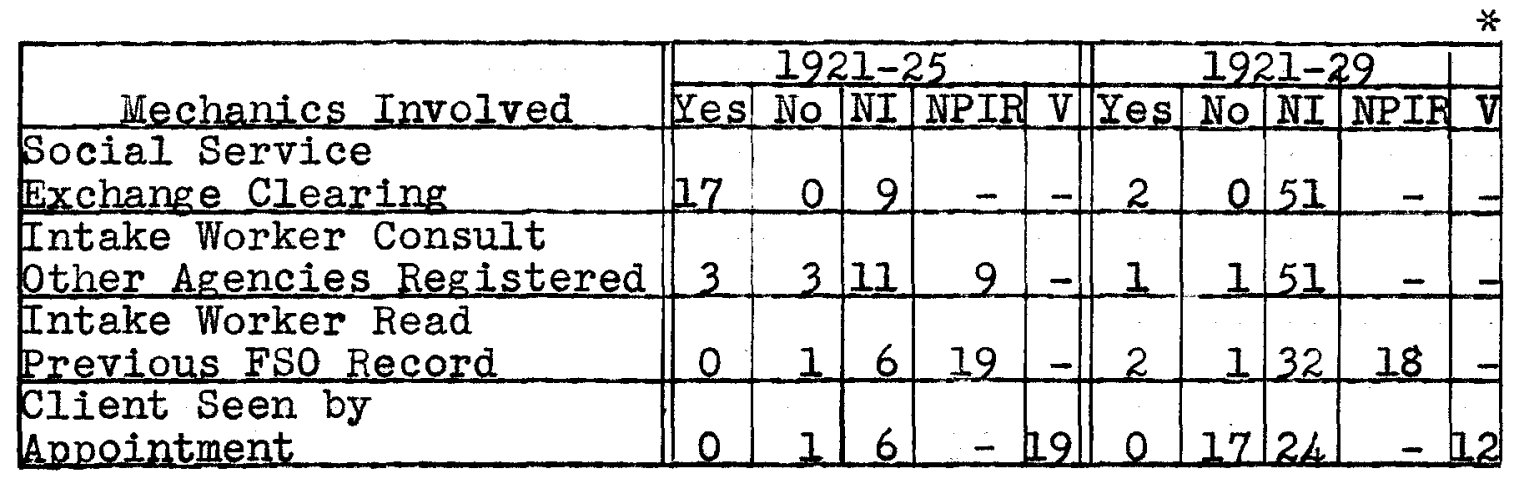

Table XIX

Who Saw the Client at Intake 1921 - 1929

\begin{tabular}{|l||c|c|r|}
\hline Who Saw the Client & $1921-25$ & $1925-29$ & Total \\
\hline $\begin{array}{l}\text { Intake Secretary } \\
\text { Caseworker Who } \\
\text { Continues with Case }\end{array}$ & 0 & 2 & 2 \\
\hline $\begin{array}{l}\text { Saturday } \\
\text { Afternoon Worker }\end{array}$ & 0 & 7 & 7 \\
\hline Night Clerk & 1 & 0 & 1 \\
\hline $\begin{array}{l}\text { Caseworker Who Did Not } \\
\text { Continue with Case }\end{array}$ & 0 & 2 & 2 \\
\hline Worker Visited in Home & 19 & 12 & 31 \\
\hline Not Indicated & 6 & 29 & 35 \\
\hline- & 26 & 53 & 79 \\
\hline
\end{tabular}

*Key to Table XVIII: NI - Not Indicated

NPIR - No Previous Inquiry Registered $\mathrm{V}$ - Visit 
Application Form Used by the Family Service Organization 1939 - 1940

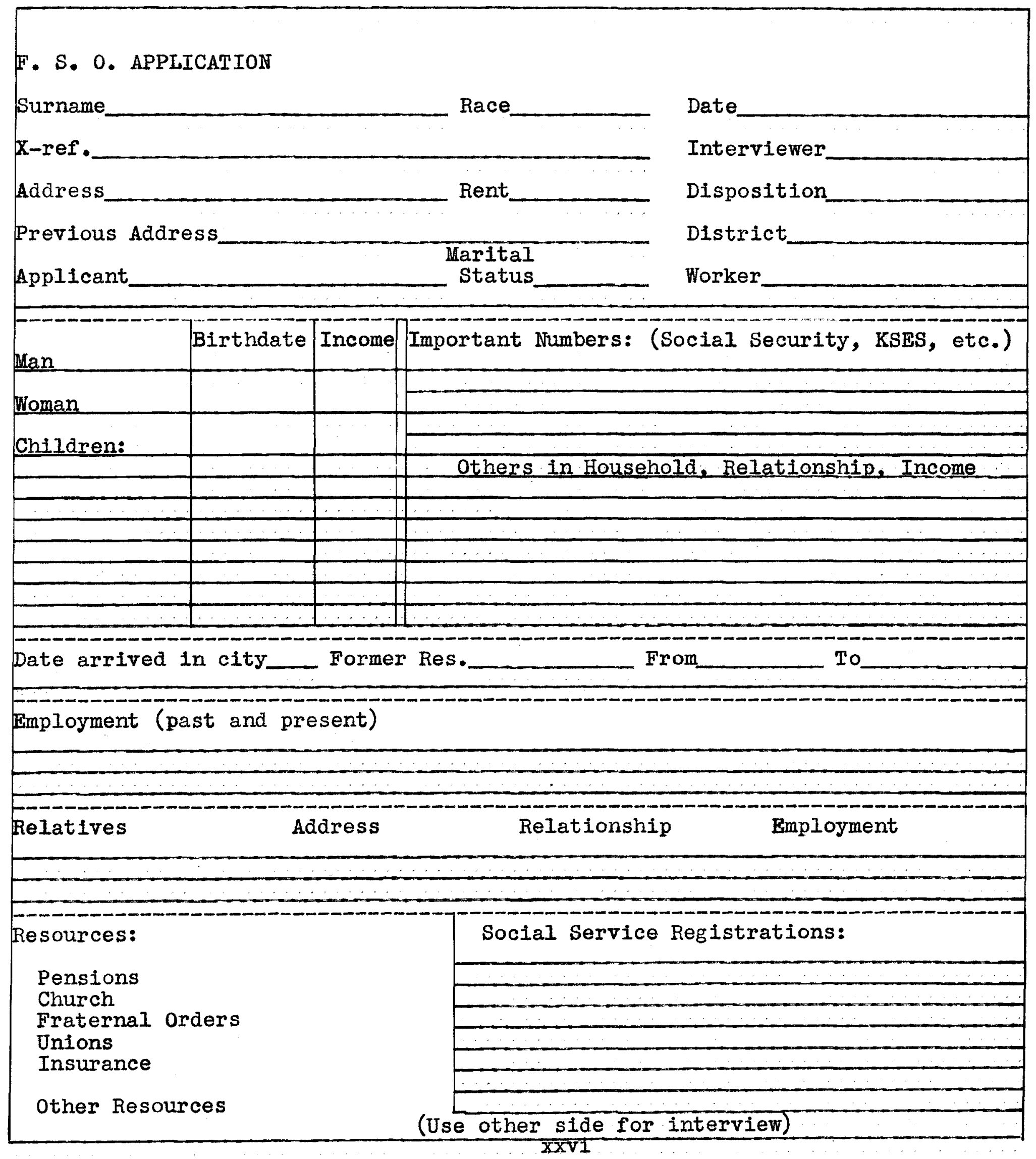




\section{INTERPRETATION OF CLASSIFICATION OF PROBLEMS}

\section{CLASSIFICATION}

1. Physical - Ph

Undernourished

Menopause

Handicapped -

Blind

old Age

Failure, indifference to accept medical care Maternity

2. Mental - M

Neurasthenia

Psychoneurosis

Psychosis

Mental Deficiency -

Feeblemindedness

3. Personality Problems - PE

Dependency

Inadequacy

Immaturity

Inability to stand pressure and take responsibility

Inability to face reality

Nervousness

Behavior problems

Cruelty

Drug Addiction

Alcoholism

Emotional stress -

need for emotional adjustment

emotional conflict

emotional immaturity

need to understand behavior of another individual anxieties

bitterness

4. Economic Problems - E

Insufficient income 
Indebtedness

Economic Insecurity

Need for adjustment to changed standard of living

Need for help in budgeting and financial planning

Insurance

Employment -

periodic employment

seasonal employment

under-employment

unemployment

5. Family Relationship - F.R.

Inadequate parental care -

Mother working - no supervision for children

Inability to discipline children

Inability to counsel children

Rejection of children by parents

Lack of supervision of children

Illegitimacy

Neglect of children

Unadjusted member to family group

Conflict between members of family

Widower with dependents

Unfriendliness of relatives

Inability of relatives to assist in planning

Problems of adolescence

Adolescent assuming supporting role in family

Over-dependence on parents

Non-contributing children

Delinquency

Need for vocational adjustment and guidance

Domestic difficulties

Incompatibility

Infidelity

Desertion

Separation

Divorce

Non-support

Broken home

Young couples experiencing difficulties in establishing home

6. Community Relationship - C.R.

Work relationships -

Lack of security in work

Inability to hold job

Untrained for work

Adjusting to work situation 
Compensation adjustment

Conflict with community -

Gambling

Stealing

Forgery

Immorality

Incarceration

Ex-convict

Need for recreational activities

Lack of recreational facilities 
BIBLIOGRAPHY 


\section{BIBLIOGRAPHY}

\section{Books}

Richmond, Mary. What Is Social Case Work?. Russell Sage Foundation, New York, 1922.

Richmond, Mary. The Long View. Russell Sage Foundation, New York, 1930.

Richmond, Mary. Social Diagnosis. Russell Sage Foundation, New York, 1917.

Hamilton, Gordon. Social Case Recording, Theory and Practice of Social Case Work. Columbia University, 1940.

Hollis, Florence. Social Casework in Practice, Six Case Studies. Family Welfare As sociation of America, 1939.

Social Work Year Book 1929.

Social Work Year Book 1939.

The Journal of Social Work process, the Relation of Function to Process in Social Work Process, November 1937. V. 1, No. 1. Pennsylvania School of Social Work.

Edited by

Wessel, Rose. Method and Skill in Public Assistance, The Journal of Social Work Process, December 1938. V. 1, no. 1, Pennsylvania School of Social Work.

Proceedings of the National Conference of Social Work. The University of Chicago Press, Oetober 1923.

Gurteen, The Rev. S. Humphreys. A Handbook of Charity Organization. Published by the Author, 1882 .

Edited by

McCulloch, James E. The South Mobilizing for Social Service. Southern Sociological Congress, 1913. 


\section{Periodicals}

Lowry, Fern. "Problems of Therapy in Family Case Work". Social Service Review, $\nabla . X$, no. 2. Jan. 1936.

Swift, Iinton B. "Declining Intake - Newly Revealed Needs". Highlights, v. II, no. 2. April 1941.

Mills, Harriett J. "The Prognostic Value of the First Interview". Smith College Studies in Social Work. Sep. 1937.

Ritterskampf, Louise. "First Interview as a Guide to Treatment". Smith College Studies in Social Work. Sep. 1937.

Root, Harriet E. "The Changing Function of an Agency as Reflected in Intake" (abstract of thesis). Smith College Studies in Social Work. Dec. 1940.

Articles from The Family:

Wallerstein, Helen. "New Trends in Casework as Developed by the Depression". V. XV, no. 7. Nov. 1934.

Whitehead, Mary. "A Satisfactory Relationship in the Early Contacts with the Client". V. XV, no. 9. Jan. 1935.

Hamilton, Gordon. "Refocusing Family Casework". V. XII, no. 6. Oct. 1931.

no. 5. Juily 1937.

"Basic Concepts in Social Caswork." V. XVIII,

Potter, Crystal M. and Austin, Lucille N. "The Use of the Authoritative Approach in Social Casework". V. XIX, no. 1. March 1938.

HcCord, Elizabeth. "Treatment in Short Time Contacts". V. XII, no. 6. Oct. 1931.

Aptekar, Herbert H. "The Continuity of Intake and Treatment Processes". V. XVIII, no. 1. March 1937.

Moorhead, Muriel. "What Is Involved in Simplicity of Treatment?". V. XVIII, no. 7. Nov. 1937.

Hurlin, Ralp G. "Relief in Private Family Agencies in the Post-Depression Period". V. XVIII, no. 4. June, 1937. 
Levey, Beatrice. "The Intake Interview from the Standpoint of Supervision". V. XX, no. 9. Jan. 1940.

Marnel, Sarah S. "Intake Process in a Public Assistance Ag ency". V. XXI, no. 4. June 1940.

Finlayson, Alan D., M.D. "The Diagnostic Process in Continuing Treatment". V. XVIII, no. 7. Nov. 1937.

Day, Florence R. "Changing Practices in Casework Treatment". V. XVIII, no. I. March 1937.

Cannon, Antoinette. "Where the Changes in Social Casework Have Brought Us". V. XV, no. 9. Jan. 1935. 


\section{Pamphlets}

Intake in Public and Private Agencies, reprints from The Family. Family Welfare Association of America, 1938:

Mullikan, Louise. "At the Intake D্নesk". Feb. 1933.

Kahn, Dorothy C. "Experiment in Selective Intake in a Family Society". March 1932.

Levey, Beatrice Z. "The Extent of the Intake Interview". December 1933.

Houwink, Eda. "Treatment in Intake Procedure". March 1936.

Family Welfare Association of America publications: Maxwe11, Virginia. Central Application Bureaus. 1935.

Todd, Helaine and Guignon, Harriet. Defining Family Casework Services in Relation to Client Applications. 1938 .

Differential Approach in Casework Treatment. 1936.

Interviews, Interviewers, and Interviewing in Social case Work.

Swift, Linton B. New Alignments between Public and Private Agencies. 1934.

Family Welfare Association of America leaflets:

The Intake Interview. Milwaukee Family Welfare Association. (Notes taken at an Institute at ininnesota University July 1940 -- course by Dr. Leroy in. A. Maeder.)

Intake Report. Springfield Family Welfare Association. Nov. 1938.

Report of the Intake Committee. Atlanta Family Welfare Association. 1939.

Study of Intake Procedure. Wheeling Family Service Assoction. 1939. 
Studies Made by the Family Service Organization Staff Members

Cohen, Ruth; Ginsberg, Blanche; Edwards, Ruth; and Benedict, Sarah. "Graphical and Tabular Presentation and Interpretation of Some Phases of the Work of the Family Service Organization of Louisville, Kentucky, during the Years 1929 - 1936 based on Monthly Averages from the Yearly Reports of That Organization". Hay 1937.

Tynes, Harriet. "Some of the Facts Found by a Study of 100 Families Rejected by the Family Service Organization in 1930".

Prinz, Marian E. "A Study of Intake in the Family Service Organization, Major and Minor Acceptances for July, August, and September 1939".

\section{Miscellaneous}

The Louisville Community Chest Survey. 1939.

Bulletin of the Council of Social Agencies of the Louisville Community Chest. April 10, 1940. And Annual Report as of illay 1940.

Brochure published by the Family Service Organization Board concerning change in function of the agency following transfer of major relief responsibility to the public agency. May 1938.

Family Service Organization inaterial, including: Case ilaterial

Minutes of Board Meetings and Board Committee Meetings Executive Reports

Case Policy Committee Reports

Staff Intake Committee Minutes for 1937 and 1939

Agency Annual Reports

Monthly and Yearly Service Reports

Annual Reports of the Welfare League

Agency Memoranda

Bernice Ellis. "The History of the Family Service Organization 1884 - 1939". Unpublished master's thesis, Division of Social Administration, University of Louisville.

Bateman, Mildred. "Lay Participation in the Private Family Agency, Louisville, Kentucky". Unpublished lifaster's thesis, Division of Social Administration, University of Louisville. 